\title{
RESISTÊNCIA À FRATURA DE RAÍZES FRAGILIZADAS RESTAURADAS COM RESINA COMPOSTA E PINOS DE FIBRA DE VIDRO SUBMETIDAS À CICLAGEM MECÂNICA
}

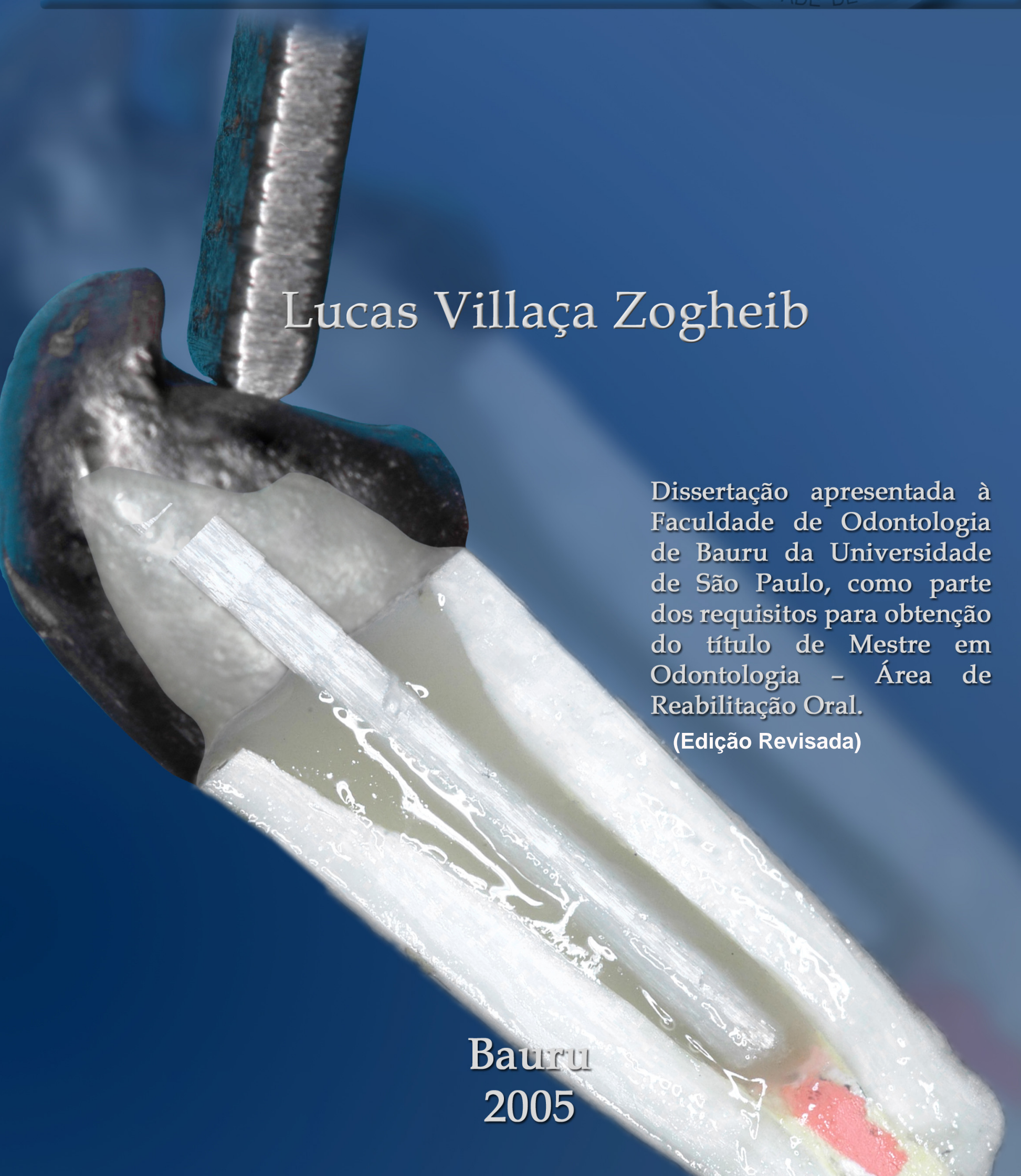




\section{RESISTÊNCIA À FRATURA DE RAÍZES \\ FRAGILIZADAS RESTAURADAS COM RESINA \\ COMPOSTA E PINOS DE FIBRA DE VIDRO SUBMETIDAS À CICLAGEM MECÂNICA}

\section{Lucas Villaça Zogheib}

Dissertação apresentada à Faculdade de Odontologia de Bauru da Universidade de São Paulo, como parte dos requisitos para obtenção do título de Mestre em Odontologia - Área de Reabilitação Oral.

(Edição Revisada)

Orientador: Prof. Dr. Accácio Lins do Valle 


\section{Z73r Zogheib, Lucas Villaça \\ Resistência à fratura de raízes fragilizadas restauradas com resina composta e pinos de fibra de vidro submetidas à ciclagem mecânica/ Lucas Villaça Zogheib. Bauru, 2005. \\ xxvi,164 p.:il., $30 \mathrm{~cm}$. \\ Dissertação (Mestrado) -- Faculdade de Odontologia de Bauru Universidade de São Paulo. \\ Orientador: Prof. Dr. Accácio Lins do Valle}

Autorizo, exclusivamente para fins acadêmicos e científicos, a reprodução total ou parcial desta tese, por processo fotocopiadores e/ou meios eletrônicos.

Assinatura do autor (a):

Data:

Projeto aprovado pelo Comitê de Ética da Faculdade de Odontologia de Bauru - USP, em reunião realizada no dia 23/02/2005.

Protocolo n.: 01/2005 
Lucas Villaça Zogheib

28/04/1979

Bauru-SP

$1997-2000$

2001

2001-2002

2002

2003-2005

Associações
Nascimento

Curso de Odontologia-Universidade do Sagrado Coração-Bauru-SP

Capacitação Profissional em Periodontia Faculdade de Odontologia de Bauru - USP

Aperfeiçoamento em Dentística-Universidade do Sagrado Coração-Bauru-SP

Estágio no Departamento de Prótese da Faculdade de Odontologia de Bauru - USP

Curso de Pós-Graduação em Odontologia, área de concentração Reabilitação Oral, em nível de Mestrado, na Faculdade de Odontologia de Bauru - USP

APCD - Associação Paulista de Cirurgiões Dentistas

SBPqO- Sociedade de Brasileira de Pesquisa Odontológica 


\section{DEDICATÓRIA}

\section{Ao ETERNO PAI}

por me amar imensamente em cada segundo desta vida;

\section{A MINHA MÃE,}

ANA MARIA LINS VILLAÇA ZOGHEIB, ex-professora desta Faculdade, pelo exemplo de humildade e dedicação na carreira docente. 


\section{AGRADECIMENTOS ESPECIAIS}

Ao meu pai Eduardo, pelo testemunho da sua vida, pela sua história, pela sua fé inabalável, pela sua fidelidade ao seu ideal, pelo seu amor incondicional aos seus maiores patrimônios: seus filhos. Você é o meu maior exemplo. Que Deus me permita conseguir retribuir tudo isto

A minha mãe Cláudia, pela sua coragem em tão jovem nos assumir como filhos e mais do que isso, por nos doar irmãos maravilhosos e uma família muito especial;

Aos meus queridos irmãos: Paulo, Renata, André, Nassif e Marcela pela existência de cada um de vocês na minha vida, amo muito vocês;

A minha querida Tatiana pela sua sensibilidade, pela sua confiança na minha capacidade, pelo seu companheirismo e pelo seu amor incondicional. Que Deus continue a ser a pessoa mais importante no nosso relacionamento para que juntos possamos nos realizar ainda mais nesta vida.

Ao Movimento dos Focolares representado por diversas pessoas que mostraram o quanto Deus me ama, ensinaram-me como ser um cristão mais autêntico, vendo a figura de Jesus em cada pessoa e tratando-a como Tal, amando cada um por primeiro, inclusive o inimigo. E quando nada disso foi feito...me ensinaram ainda: recomeçar sempre, pois como descendentes do

divino e, apesar de humanos, TODOS somos potenciais candidatos a santidade. 


\section{AGRADECIMENTOS}

À CAPES pelo apoio financeiro indispensável para a realização desta pesquisa;

À ANGELUS, Indústria de Produtos Odontológicos, pelo fornecimento dos pinos de fibra de vidro utilizados nesta pesquisa;

Ao Prof. Dr. Mário Alexandre Coelho Sinhoreti, do Departamento de Materiais Dentários da Faculdade de Odontologia de Piracicaba, Universidade de Campinas, UNICAMP, pela autorização na utilização da máquina de ciclagem mecânica;

À Faculdade de Odontologia de Bauru - Universidade de São Paulo, representada por sua Diretora Profa. Dra. Maria Fidela de Lima Navarro, pelo constante esforço em favorecer o melhor ambiente para a pesquisa e convívio entre as pessoas;

Aos funcionários da Biblioteca, pelos valiosos ensinamentos e pela atenção dispensada na localização dos trabalhos revisados e consultados;

Aos funcionários da Pós-Graduação, pela dedicação em sempre atender nossas necessidades, especialmente ao Eduardo, a Giane, a Letícia, a Cleuza e ao Israel; 
Aos funcionários do Departamento de Prótese, em especial a Cláudia, a Débora, o Riva, o Marcelo, e a Walquíria pela solicitude imediata em nos atender;

A Edna, ex-secretária do Departamento de Prótese, pela ajuda e interesse por cada aluno;

Ao Prof. Dr. José Roberto Pereira Lauris e a Prof. Drª. Teresinha Torneiro (professora aposentada da Faculdade de Medicina da UNESPBotucatu) pela análise estatística deste trabalho;

Aos demais Professores da Faculdade de Odontologia de Bauru, que colaboraram com nosso aprendizado durante o curso;

Aos Professores do Departamento de Prótese, pela aceitação da minha pessoa na participação deste programa de mestrado;

Em especial o meu orientador, o Prof. Dr. Accácio Lins do Valle, professor e amigo, que despertou em mim o interesse pela carreira universitária;

Aos Profs. Drs Luiz Fernando Pegoraro, Gérson Bonfante, José Henrique Rubo, Paulo César Rodrigues Conti, Paulo Martins Ferreira, Carlos dos Reis Pereira de Araújo, Vinicius Carvalho Porto, Lucimar Falavinha Vieira, Wellington Cardoso Bonachela, Milton Carlos Gonçalves Salvador, Renato de Freitas, pelos ensinamentos e pela convivência agradável nestes anos; 
Aos colegas de Doutorado: Ana Lúcia, Eduardo Ayub, Jefferson, Leylha, Luis Gustavo, Marinelli, Marli, Osvaldo, Paulo Rossetti, Paulo Fukashi, Rafael, Renato, Ricardo e Tatiany, pelos conselhos e convivência nesta etapa da minha vida;

Aos amigos do Mestrado de 2005, Fernandinho, Romão, Dudu, Jefferson Sanada e Thiago pela convivência agradável;

Aos meus queridos amigos de Mestrado, Érico, Estevam, Filipe, Jonas, Kátia, Lívia, Mariana, Mikaela, Patrícia, Rodrigo, Thânia e Valdey, pelo relacionamento pessoal estabelecido com cada um. Por trás de cada desafio que superei durante o curso estava o carinho e a atenção de vocês $\mathrm{Na}$ falta de condução não faltaram às caronas; na falta de um computador ou máquina fotográfica sobraram vários equipamentos, na falta de agilidade na clínica não faltaram companhias, na falta de motivação não faltou incentivo. Obrigado a todos;

Aos meus pacientes, pela confiança em nosso trabalho, em especial à Dona Teresinha, que se tornou uma grande amiga;

E, a todos que desprendidamente colaboraram nas mais variadas fases de execução deste trabalho e também na minha formação como professor e pessoa, a nossa sincera gratidão. 
“Não somos nós, míseros e limitados, sozinhos e sofredores, que agimos na vida. Conosco caminha o Onipotente. E quem a Ele fica unido produz muito fruto."

Chiara Lubich 


\section{SUMÁRIO}

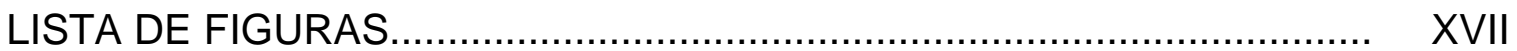

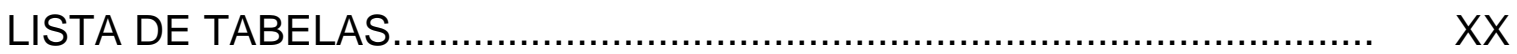

LISTA DE ABREVIATURAS E SÍMBOLOS............................................ XXI

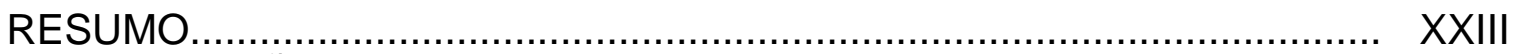

1 INTRODUÇÃO

2 REVISÃO DE LITERATURA....................................................... 9

2.1 Revisões de literatura................................................................. 11

2.2 Estudos laboratoriais.................................................................. 21

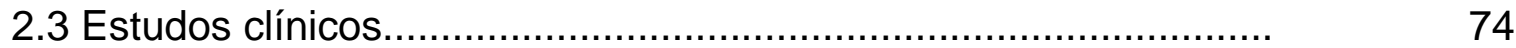

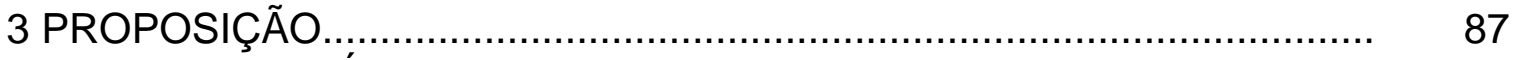

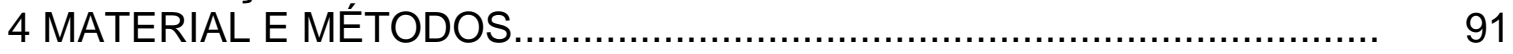

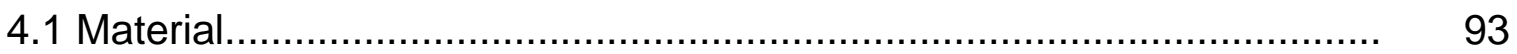

4.2 Seleção dos dentes, limpeza e armazenamento.................................. $\quad 95$

4.3 Tratamento endodôntico.............................................................. 96

4.4 Montagem dos corpos de prova ..................................................... 96

4.5 Constituição dos grupos.................................................................. 97

4.6 Preparo das raízes............................................................... 98

4.7 Reconstrução das raízes fragilizadas................................................. 103

4.8 Cimentação dos pinos.............................................................. 105

4.9 Construção da porção coronária....................................................... 106

4.10 Confecção das coroas totais metálicas............................................. 107

4.11 Cimentação das coroas........................................................... 108

4.12 Teste de ciclagem mecânica.......................................................... 111

4.13 Teste de resistência à fratura...................................................... 113

4.14 Análise do padrão de fratura..................................................... 115

4.15 Análise estatística dos resultados................................................ 115

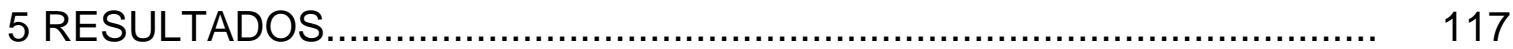

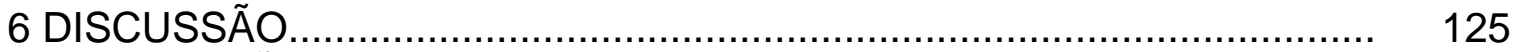

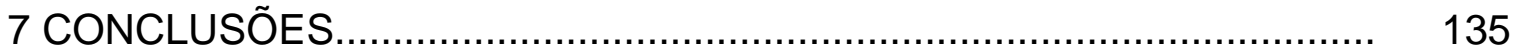

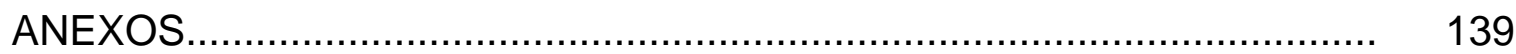

REFERÊNCIAS BIBLIOGRÁFICAS...................................................... 145

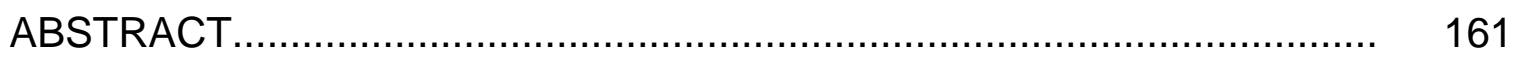




\section{LISTA DE FIGURAS}

Figura 1 - (A) Inserção do dente seguindo o longo eixo do cilindro de PVC e resina acrílica (B) Fixação do dente com resina Duralay (C) Espaço de 3,0 mm simulando as distâncias biológicas. 97

Figura 2 - Representações de raízes com diferentes espessuras de remanescentes radiculares classificadas em: (grupo I) íntegras, (grupo II) parcialmente fragilizadas e (grupo III) amplamente fragilizadas. .98

Figura 3 - (A) Pino no 3 (1,5 mm de diâmetro) com respectiva broca de Peeso número 5 (B) Representação da profundidade desgastada 99

Figura 4 - (A) Ponta diamantada 1016 HL utilizada no primeiro desgaste até a profundidade de 9mm (B) Ponta diamantada $3017 \mathrm{HL}$ utilizada no segundo desgaste até a profundidade de $5 \mathrm{~mm}$ alcançando o terço médio 100

Figura 5 - (A) Controle da espessura dentinária a ser desgastada através de demarcação prévia com marcador permanente verde e (B) após desgaste com especímetro. 100

Figura 6 - Pontas diamantadas utilizadas no grupo III, com as respectivas profundidades de desgaste: (A) $1016 \mathrm{HL}, 9 \mathrm{~mm}$ de profundidade até o terço apical (B) $3017 \mathrm{HL}, 5 \mathrm{~mm}$ de profundidade até o terço cervical (C) 3018, 3mm de profundidade até o terço cervical.......101 
Figura 7 - (A) Marcação feita na ponta diamantada (B) Sonda periodontal controlando a profundidade de desgaste. 102

Figura 8 - Profundidades e espessuras de desgastes realizados em cada grupo. .102

Figura 9 - Incremento de resina composta aplicado dentro do conduto com espátula para resina e fotopolimerização com auxílio do pino plástico fototransmissor .104

Figura 10 - (A) Preenchimento do conduto desde sua porção mais apical com auxílio de pingador de cera (B) Novo conduto obtido. 104

Figura 11 - Pinos cimentados após fotopolmerização do cimento. .106

Figura 12 - Matriz e padrão metálico. 106

Figura 13 - (A) Matriz de acetato a partir de padrão metálico (B) Matriz adaptada para confecção dos núcleos (C) Núcleo em resina composta obtido pela matriz. 107

Figura 14 - (A) Dente natural íntegro posicionado sobre o corpo de prova (B) moldagem do conjunto (corpo de prova/ coroa íntegra/ fio de cera) (C) molde do conjunto; (D) cera aspirada com uma seringa hipodérmica de vidro. 108

Figura 15 - (A) Núcleo de preenchimento vaselinado (B) excesso de cera removido a partir do término $(C)$ adaptação marginal e fio de cera sobre a superfície palatina. 109

Figura 16 - Coroa total metálica fundida em NiCr adaptada ao espécime....110 
Figura 17 - Cimentação da coroa com aparato para padronização da carga e direção da força.

Figura 18 - Máquina utilizada para ciclagem mecânica. 112

Figura 19 - Disposição dos corpos de prova no interior da máquina de ciclagem mecânica. 112

Figura 20 - Força de compressão foi aplicada $3,0 \mathrm{~mm}$ abaixo da ponta incisal. 113

Figura 21 - Visualização das duas matrizes metálicas que permitiram a acomodação do corpo de prova a ser carregado (A - vista frontal, B - vista lateral) 114

Figura 22 - Representação gráfica das médias de resistência à fratura dos três grupos experimentais 120

Figura 23 - Localização e freqüência das fraturas nos 3 grupos avaliados..122 


\section{LISTA DE TABELAS}

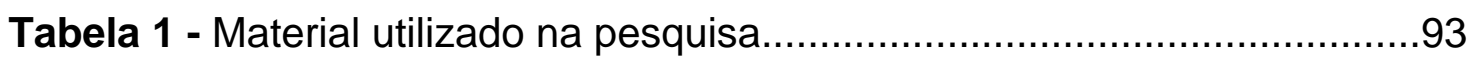

Tabela 2 - Valores de carga máxima individuais, médias e respectivos desvios padrão para cada condição experimental (valores em kgf). 119

Tabela 3 - Teste estatístico de análise de variância a um critério aplicado aos valores de resistência à fratura..............................................121

Tabela 4 - Comparações individuais das médias - Método de Dunnett........121

Tabela 5 - Porcentagem dos espécimes quanto à possibilidade de reabilitação pós fratura conforme grupo. .123 


\section{LISTA DE ABREVIATURAS E SÍMBOLOS}

Bis-GMA - bisfenol -A- glicidilmetacrilato

Cu-Al - Liga de cobre-alumínio

G - Grupo

HL - Haste Longa

NMF - Núcleo Metálico Fundido

$\mathrm{Ni}-\mathrm{Cr}$ - Liga de níquel-cromo

MDP - 10 metacriloiloxidecil dihidrogênio fosfato

MEV - Microscopia Eletrônica de Varredura

M-D - Mésio-Distal

V-P - Vestíbulo-Palatino

- - Grau

${ }^{\circ} \mathrm{C}$ - Graus Celsius

$\mathrm{Hz}-\mathrm{Hertz}$

Kg - Kilograma

Kgf - Kilograma-força

$\mu \mathrm{m}$ - Micrometro

$\mathrm{MPa}$ - Mega Pascal

mm - Milímetro

$\min$ - Minuto

n - Número de amostras

$\mathrm{N}$ - Newton

no - Número

X - Número de vezes 
RESUMO 


\section{RESUMO}

A preservação e a restauração de dentes severamente debilitados sem suporte dentinário no terço cervical do canal radicular é um procedimento difícil e de prognóstico duvidoso. Avaliou-se, por meio de ciclagem mecânica e compressão, a resistência à fratura e o padrão de fratura de raízes íntegras e fragilizadas, reconstruídas internamente com resina composta ( $Z$ 250) e pinos de fibra de vidro (Reforpost). Trinta caninos superiores humanos com anatomia radicular semelhante foram divididos em três grupos de acordo com a espessura do terço cervical: grupo I - raízes íntegras sem simulação de enfraquecimento e grupos II e III simularam raízes parcial e amplamente enfraquecidas. Estas foram reconstruídas através de preenchimento com resina composta fotopolimerizável por meio de um pino translumínico (Luminex). Todos os grupos tiveram coroas totais metálicas cimentadas sobre os núcleos em resina composta. Os pinos e coroas foram cimentados com cimento resinoso dual. Os corpos de prova foram submetidos à 250.000 ciclos numa freqüência de $2.6 \mathrm{~Hz}$ e carga de $3 \mathrm{Kg}$. Posteriormente, os mesmos foram carregados numa máquina de ensaio universal à uma velocidade de carga de $0,5 \mathrm{~mm} / \mathrm{min}$ até sua fratura. Em ambos os testes a angulação de carga foi de $135^{\circ}$ em relação ao longo eixo do dente sobre a face palatina. Os valores de resistência à fratura foram: Grupo I-57,83Kgf; Grupo II-41,80 Kgf; Grupo III-41,93 Kgf. A análise de variância (ANOVA) $(p<0,05)$ a um critério mostrou diferença estatisticamente significante entre os grupos. A comparação individual das médias revelou diferença somente entre o grupo I e os grupos II e III. O percentual de raízes 
com prognóstico favorável após a fratura foi: Grupo I -80\%; Grupo II -40\%; Grupo III -30\%. Raízes fragilizadas foram menos resistentes à fratura e apresentaram menos fraturas favoráveis a reabilitação do que aa raízes íntegras. 
1 - INTRODUCCÃO 


\section{1 - INTRODUÇÃO}

A restauração de dentes tratados endodonticamente, apesar de já ser praticada há anos, continua sendo um desafio para os cirurgiões dentistas 21,52,55,, 97 . Os problemas estão relacionados, principalmente, com a extensa destruição coronária causada por lesões cariosas, traumas ${ }^{16}$, acesso para a instrumentação radicular e restaurações realizadas anteriormente $21,37,52,79,80,83$. Isto faz com que estes dentes sejam mais propensos à falhas biomecânicas do que os dentes vitais ${ }^{2,16,21,37,73,79,80,90,92,93,94,98}$. A ausência da maior parte da estrutura coronária pode inviabilizar uma restauração direta $^{52,83}$, fazendo com que seja necessário reconstruções com pinos intraradiculares para a retenção e suporte adequado de coroas protéticas ${ }^{7,15,81}$.

Dessa maneira, desde o século XVIII têm sido relatadas diversas técnicas para a reconstrução de dentes desvitalizados, empregando dispositivos intra-radiculares capazes de oferecer retenção e suporte para uma restauração indireta ${ }^{83}$.

Em 1728, Pierre Fauchard descreveu o uso de pinos metálicos parafusados nas raízes dos dentes para reter suas próteses. Em 1746, Claude Mouton publicou o desenho de uma coroa de ouro, com pino da mesma liga usado como retentor intra-radicular ${ }^{83}$. Em 1891, o uso de uma coroa pivot, foi recomendado ${ }^{52}$. Também durante metade do século $\mathrm{XIX}$, foi muito utilizado a coroa de Richmond, retida por pino com uma faceta de porcelana objetivando reconstruir a estética dos pacientes ${ }^{83}$. 
Após várias décadas de uso, as coroas e núcleos numa só peça foram gradualmente substituídos pelos núcleos metálicos fundidos feitos separadamente da coroa $^{81}$. Tal técnica permitiu uma adaptação marginal sem a limitação da trajetória de inserção da coroa exclusivamente no longo eixo do dente, além do que, uma restauração insatisfatória poderia ser substituída sem a remoção do pino ${ }^{81,83}$.

Somente nos anos sessenta, o uso de pinos pré-fabricados e materiais restauradores plásticos foram introduzidos ${ }^{9,20}$. A partir de então, a praticidade e o menor custo fizeram com que cada vez mais se utilizassem estes pinos. No entanto, principalmente pela limitação estética dos pinos metálicos, como o acinzentamento das coroas totais cerâmicas translucentes e também da margem gengival adjacente, houve o desenvolvimento de pinos e núcleos livres de metal que tivessem uma coloração mais próxima a do dente ${ }^{3,5,62,63,66}$. A partir do final da década de oitenta foram desenvolvidos pinos cerâmicos e pouco tempo mais tarde os pinos de fibra ${ }^{2}$. Os sistemas de pinos reforçados por fibra foram introduzidos quando DURET, et al., em 1990, descreveram um material não metálico para a fabricação de pinos, baseado no princípio de reforço pela fibra de carbono $^{10}$. A cor preta da fibra de carbono levou a introdução de fibras translucentes e da cor do dente. Os pinos resinosos suportados por fibra de vidro foram introduzidos em 1992. Estes pinos são compostos por fibras de vidro unidirecionais envolvidas numa matriz resinosa que reforça o pino sem comprometer seu módulo de elasticidade ${ }^{94}$. Além destes, existem no mercado odontológico, pinos resinosos reforçados por quartzo ${ }^{10,23,30}$. 
A restauração de dentes tratados endodonticamente com materiais livres de metal, que possuam propriedades físicas similares as da dentina, tem sido sugerida na odontologia restauradora ${ }^{2}$. Alguns autores têm dado ênfase ao uso de pinos feitos com materiais que apresentem propriedades biomecânicas similares às do dente ${ }^{2,42,88}$. Outros afirmam que não só o desenho, mas também o material do pino e do núcleo afetam a resistência à fratura de dentes tratados endodonticamente ${ }^{2}$. Até recentemente, todos os pinos pré-fabricados disponíveis consistiam de ligas metálicas que resultavam numa combinação final heterogênea de dentina, pino metálico, cemento e material restaurador para a confecção do núcleo ${ }^{2}$. Pinos com propriedades muito diferentes às da dentina e outros materiais envolvidos na restauração, têm a principal desvantagem de concentrar estresse em áreas não controladas e vitais para os dentes tratados endodonticamente ${ }^{2}$. Os pinos resinosos, como os reforçados com fibra de vidro, por apresentarem módulo de elasticidade mais próximo ao da dentina, distribuem o estresse sobre uma área de superfície mais ampla, diminuindo o risco de fratura radicular ${ }^{8,25,42,94}$.

Em certas situações a destruição da estrutura dentária se estende para o interior radicular como resultado da cárie, de fraturas, da remoção de pinos cimentados anteriormente, de tratamento endodôntico mal executado, de reabsorção interna ou de causas idiopáticas ${ }^{43,44,46,52,62}$. A destruição radicular interna que alarga o canal, enfraquece a raiz, deixando-a mais susceptível a fraturas, tornando o procedimento restaurador mais difícil 16,43,44,46,52,55,62. Para evitar a extração de raízes enfraquecidas, o 
preenchimento dos defeitos radiculares com materiais restauradores, como o cimento de ionômero de vidro, cimento resinoso, resina composta e cimento de ionômero de vidro modificado por resina e/ou pinos intra-radiculares têm sido sugerido $16,43,44,46,52,55,62,78$.

Segundo vários autores ${ }^{29,55,56,57,77,84,85}$, o preenchimento de raízes amplamente destruídas utilizando técnicas adesivas, que aumentem a espessura das paredes radiculares e diminuam o calibre dos condutos, podem reforçar estes remanescentes. Isto pela confecção de pinos com paredes mais paralelas que minimizem a concentração de estresse no ápice radicular. Além disso, poderá haver ainda um aumento da retenção do núcleo. Desta maneira, dentes severamente danificados, antes condenados à extração, poderão ser preservados por estas técnicas restauradoras ${ }^{16,52}$.

RABIE et al ${ }^{69}$, em 1985, apresentaram um trabalho sobre o reforço e a restauração de dentes com rizogênese incompleta com condutos amplos através de uma técnica utilizando ataque ácido e resina composta. Após o condicionamento ácido, uma resina era injetada no conduto radicular com um pino inoxidável posicionado criando um novo conduto radicular de menor diâmetro para o núcleo. Os autores concluíram que esta técnica poderia ser um método restaurador de reforço para estes dentes.

Concordando com eles, LUI ${ }^{43}$, em 1987, divulgou uma técnica de reforço para dentes tratados endodonticamente com raízes debilitadas em sua porção cervical e afirmou que uma camada suficiente de resina seria responsável pelo reforço radicular. Esta permitiria a colocação de um pino 
metálico em todas as situações em que o mesmo fosse requerido para o restabelecimento da função fisiológica de um dente destruído.

GODDER; ZHUKOVSKY; BIVONA ${ }^{29}$, em 1994, descreveram uma técnica de reforço radicular com resina composta fotopolimerizável utilizando um pino translúcido. Através deste, a luz seria transmitida ao longo do conduto, atingindo regiões mais apicais e assim se obteria uma polimerização mais uniforme da resina. Observaram que este sistema poderia auxiliar na restauração de dentes tratados endodonticamente pela combinação de agentes adesivos e materiais resinosos.

MARCHI ${ }^{51}$, em 1997, e SOARES ${ }^{84}$, em 1999, avaliando diferentes materiais aplicados na reconstrução de dentes fragilizados, demonstraram que nenhum dos sistemas restauradores utilizados foi capaz de recuperar a resistência à fratura da raiz.

Recentemente CARVALHO et al. $^{16}$, em 2005, demonstraram a importância de se utilizar meios de reforço radicular em raízes com paredes dentinárias delgadas no terço coronário. A utilização de um pino de zircônia ou resina composta fotopolimerizável aumentou significativamente a resistência à fratura de raízes fragilizadas.

A introdução de materiais com capacidade de adesão dentinária resultou numa alternativa viável aos núcleos metálicos fundidos para a reconstrução de canais radiculares severamente comprometidos ${ }^{59}$. Têm se atribuído a pinos endodônticos, que possam se aderir tanto à dentina quanto ao material do núcleo, um aumento da distribuição de forças ao longo da raiz e dessa maneira uma contribuição para o reforço do dente ${ }^{44,55,78,79,82}$. Tais 
considerações foram feitas principalmente a partir de estudos laboratoriais que utilizaram uma carga constante sobre os dentes ${ }^{55,78,82}$.

Outros autores têm utilizado ciclagem mecânica ou carga cíclica na avaliação da resistência de pinos endodônticos, afirmando que desta forma haveria uma simulação mais próxima da encontrada no ambiente oral do que a aplicação de uma carga única até a falha, como é comumente realizado nos testes de resistência à fratura ${ }^{14,40,95}$. Isto ocorre porque o padrão de carga cíclica muitas vezes é comparável à função fisiológica, podendo desta maneira, prever resultados de ensaios clínicos ao longo do tempo ${ }^{67}$.

Diante da evolução atual dos sistemas de adesão dentinária, dos cimentos resinosos, assim como das próprias resinas compostas e pinos de fibra, o que permitiu restaurações com propriedades mecânicas mais próximas as da dentina, mostrou-se válido questionar se a restauração dos remanescentes radiculares debilitados, através da reconstrução destes com resina composta e pinos de fibra de vidro, é adequado como suporte de coroas protéticas. 


\section{2 - REVISÃO DE LITERATURA}




\section{2 - REVISÃO DE LITERATURA}

\section{1 - Revisões de literatura}

CAPUTO; STANDLEE ${ }^{15}$, em 1976, ressaltaram que a utilização de núcleos intra-radiculares tem a finalidade retentiva de uma restauração e não do seu reforço. O pino utilizado deveria ao mesmo tempo oferecer o benefício da retenção sem o prejuízo da concentração de estresse dentinário que pode resultar em fratura radicular. Considerou-se sua utilização uma técnica radical e na ocorrência de falha poucas soluções corretivas poderiam ser empregadas. Pinos com paredes paralelas, serrilhadas e cimentados com fosfato de zinco seriam a melhor combinação para o sucesso da prótese. Aconselharam ainda que a manutenção de pelo menos $1 \mathrm{~mm}$ de dentina íntegra ao redor de toda circunferência do canal.

Segundo WISKOTT; NICHOLLS; BELSER ${ }^{95}$, em 1995, evidências clínicas indicariam que a maioria das fraturas em estruturas protéticas ocorreria após um período de vários anos. Estas falhas geralmente não estariam relacionadas a episódios de sobre-carga, mas resultariam de um processo de fadiga. A fadiga seria o modo de fratura pelo qual uma estrutura falha depois de estar sujeita a pequenas cargas repetidas. No entanto, somente a aplicação de uma destas não seria suficiente para causar algum prejuízo ao componente. Muitos pesquisadores buscaram, por testes e investigações sistemáticas, reproduzir a falha por fadiga, chegando ao teste de carga cíclica e conceitos como o limite de fadiga. A falha de fadiga é 
explicada pelo desenvolvimento de trincas microscópicas em áreas de concentração de estresse. Com a continuidade de cargas, estas trincas fundem-se provocando o fracasso. Falhas catastróficas resultariam de um ciclo final de cargas que excedem a capacidade mecânica do material. Processos similares podem ser observados em estruturas biológicas. As falhas em prótese parcial fixa podem ser biológicas ou mecânicas, sendo que as mecânicas ocorrem entre 2,5 a 15 anos, dependendo do tipo de restauração. A maioria destas falhas é classificada como catastrófica depois de anos de uso. Avaliações de comportamento laboratorial de materiais dentários e estruturas devem ser feitas por testes dinâmicos.

SMITH; SCUMAN; WASSON ${ }^{83}$, em 1998, através de uma revisão de sistemas para pinos e núcleos estabeleceram critérios biomecânicos para cada componente do sistema restaurador. Os critérios propostos para os pinos pré-fabricados foram: resistência à carga, a corrosão, retenção, distribuição de estresse, biocompatibilidade e conservação da estrutura dentária. Para os materiais de reconstrução do núcleo os critérios foram: facilidade de uso, tempo de trabalho, resistência à carga, a microinfiltração, estabilidade dimensional, e mecanismo de adesão. Já para os cimentos os critérios reunidos foram: resistência à carga, a microinfiltração, espessura da película, solubilidade, mecanismo de adesão e facilidade de uso.

MORGANO; BRACKETT ${ }^{60}$, em 1999, publicaram uma revisão de literatura envolvendo investigações 'in vivo' e 'in vitro' com o objetivo de 
estabelecer diretrizes para a seleção de técnicas e materiais adequados à restauração de dentes estruturalmente comprometidos. Os tópicos discutidos foram: fatores desejáveis nas restaurações de suporte de dentes desvitalizados, perspectivas históricas, NMF, efeito férula, pinos préfabricados, núcleos de preenchimento, problemas e limitações de dentes com estrutura severamente comprometida, necessidades e direções para futuras pesquisas. Observaram que existe a necessidade de estudos mais calibrados, além de estudos clínicos controlados com adequado número de participantes.

FERNANDES; DESSAI ${ }^{21}$, em 2001, buscaram através de uma revisão de literatura reunir fatores que influenciam a resistência à fratura de dentes reconstruídos com pinos e núcleos. Grande parte da literatura revista enfatizou a distribuição de estresse durante a inserção e função do pino. Outros fatores identificados foram: o comprimento, o diâmetro, o material, o desenho e a adaptação do pino, a quantidade de dentina remanescente, o cimento utilizado, o material do núcleo, bem como a utilização destes dentes como pilares de próteses fixas e removíveis e a história de carga suportada por estes (hábitos parafuncionais). De todos os fatores enumerados, os mais diretamente relacionados com a longevidade dos dentes restaurados pareceram ser o desenho da coroa, as forças oclusais e a utilização de dentes já restaurados com pinos e núcleos anteriormente. Previamente a restauração aconselhou-se realizar uma avaliação das forças funcionais e 
parafuncionais. Estudos clínicos prospectivos controlados deveriam ser conduzidos avaliando cada fator.

Diante da popularidade das restaurações diretas com pinos préfabricados e núcleos de preenchimento HEYDECKE; PETERS ${ }^{34}$ conduziram, em 2002, uma revisão sistemática da literatura para comparar a performance clínica e laboratorial de NMF com núcleos de preenchimento mais pinos pré-fabricados em dentes uni-radiculares. A pesquisa sobre a restauração de dentes tratados endodonticamente foi identificada através da busca de bases eletrônicas. A busca encontrou um total de 1773 referências submetidas a um rigoroso critério de inclusão (estudos laboratoriais: dentes uniradiculares, restauração com coroa total e aplicação de carga em ângulo de $130^{\circ}$ a $135^{\circ}$ / estudos clínicos: tempo mínimo de acompanhamento de 3 anos, dentes anteriores, restaurações com coroas totais e prótese parcial fixa, descrição dos sistemas testados e sobrevivência ou sucesso dos dentes). Somente 10 estudos in vitro e 6 estudos in vivo permaneceram para a revisão propriamente dita. A comparação da resistência à fratura nos estudos laboratoriais não revelou diferença estatisticamente significativa entre os NMF e pinos pré-fabricados. Uma meta-análise de quatros estudos laboratoriais não mostrou diferenças no comportamento das fraturas associadas com as duas modalidades de tratamento. Uma análise global da sobrevivência não foi possível para os estudos clínicos por falta de dados compatíveis. A taxa de sobrevivência alcançada para os NMF ficou entre 87, $2 \%$ e $88,1 \%$ e num terceiro estudo alcançou $86,4 \%$ para pinos pré- 
fabricados após 72 meses. Ensaios clínicos randomizados sobre este tópico não estiveram disponíveis, porém deveriam ser conduzidos para verificar os achados publicados. Pode-se concluir que: laboratorialmente não há diferença significativa de resistência à fratura entre núcleos metálicos fundidos e pinos pré-fabricados; clinicamente também não houve diferença no comportamento das fraturas em relação aos dois sistemas; e as taxas de sobrevivência foram muito semelhantes em relação aos dois sistemas.

O THE DENTAL ADVISOR ${ }^{63}$, em 2003, reuniu diversas recomendações sobre a utilização de pinos não metálicos. Em relação à seleção do pino recomendou-se que: deveria ser selecionado somente para reter um núcleo e não reforçar um dente; apesar de um preparo mínimo ser necessário, canais ovóides e elípticos poderiam ser restaurados com pinos de fibra e o espaço restante do conduto seria preenchido pelo cimento resinoso; pinos de fibra de carbono poderiam resultar em escurecimento da margem gengival; pinos resinosos reforçados por fibra raramente fraturam. Para utilização de pinos em dentes anteriores deveriam ser tomados os cuidados: pino mais resistente em dentes com pouco ou nenhum remanescente; pinos de fibra deveriam ser idealmente utilizados somente na presença de um remanescente coronário de 1.5-2mm. Para pré-molares a maioria dos pinos é uma opção viável, no entanto, na presença de canais oblongos ou estreitos, com pouca estrutura coronária, os núcleos metálicos fundidos seriam mais adequados por preservarem mais o conduto e oferecer maior rigidez. Já para molares, nem sempre haveria a necessidade de pinos 
por freqüentemente se encontrar uma maior quantidade de dentina coronária remanescente. Havendo esta necessidade, a maioria dos pinos seria adequada em decorrência de retenção adicional oriunda do assoalho da câmara pulpar. Nenhum pino é considerado ideal para todas as situações.

BATEMAN; RICKETTS; SAUNDERS ${ }^{10}$ publicaram, em 2003, uma revisão de literatura sobre sistemas de pinos endodônticos a base de fibra, a partir de uma busca na base de dados MEDLINE, sobre qualquer artigo publicado em periódicos odontológicos que abordassem estes materiais. Após a aplicação de critérios de inclusão, 59 artigos foram selecionados entre estudos laboratoriais, ensaios clínicos e outros. Estes foram divididos em categorias e uma descrição subjetiva dos mesmos foi realizada. Concluiu-se que: a maior parte da literatura publicada sobre os pinos de fibra é oriunda de análises laboratoriais; as evidências sobre pinos de fibra de carbono são muito maiores do que aquelas sobre pinos de fibra de quartzo; mais investigações sobre estes pinos são necessárias antes dos mesmos serem recomendados para uso rotineiro; as evidências laboratoriais foram contraditórias e não puderam ser utilizadas como instrução prática confiável; poucos estudos clínicos têm sido conduzidos para que se confirmem estes pinos na restauração adequada de dentes tratados endodonticamente; ensaios clínicos prospectivos controlados avaliando os pinos de fibra deveriam ser conduzidos antes da adoção destes na prática clínica. 
A maioria dos dentes tratados endodonticamente requer uma reconstrução com pino e núcleo para que se obtenha uma restauração com saúde e função. A seleção de um sistema apropriado de pinos e núcleos, diante da larga variedade de materiais disponíveis, pode ser um dilema clínico. Desta maneira, FERNANDES; SHETTY; COUTINHO ${ }^{22}$, em 2003, através de uma revisão narrativa da literatura, compreendendo o período de 1961 a 2002, analisaram artigos da língua inglesa identificados pelo MEDLINE e busca manual. O objetivo do trabalho foi identificar vários fatores que poderiam influenciar a seleção de pinos e núcleos. As palavras chaves utilizadas foram: pinos, desenho, retenção, resistência à fratura, sobrevivência e estética. Importantes fatores a serem considerados na seleção de um pino intra-radicular foram citados como: comprimento radicular, anatomia do dente, largura radicular, configuração do canal, quantidade de estrutura dentária coronária, estresse, desenvolvimento da pressão hidrostática, desenho do pino, compatibilidade do material, capacidade adesiva, retenção do núcleo, retratamento, estética e tipo de coroa.

PITEL; HICKS ${ }^{66}$, em 2003, comentaram alguns parâmetros envolvidos na evolução de pinos endodônticos. A busca por restaurações livres de metal fez com que surgissem alternativas mais estéticas que permitiram eliminar desvantagens dos pinos metálicos como a descoloração da margem gengival em decorrência da oxidação e liberação dos produtos da corrosão. Além disso, a tendência de pinos rígidos, com alto módulo de elasticidade, 
transferir maior estresse funcional à estrutura dentinária, aumentando o potencial de falhas clínicas irreversíveis como as fraturas radiculares verticais, levou ao aparecimento de materiais com propriedades mecânicas mais próximas as da dentina, como os pinos resinosos reforçados por fibra. A utilização destes materiais constitui uma restauração em monobloco que tende a distribuir o esforço mastigatório de maneira mais uniforme. Outros tópicos envolvidos na utilização dos pinos, considerando principalmente aqueles reforçados por fibra de quartzo e vidro, são: uma resistência a falhas mais constante antes e depois de testes de fadiga, o ganho de retenção com a cimentação adesiva, a possibilidade de transmissão de luz e retratamento.

FOKKINGA et al. $^{24}$, em 2004, quiseram encontrar respostas para duas hipóteses a serem testadas: I - os sistemas de pinos resinosos préfabricados reforçados por resina apresentam valores de resistência à fratura similar a àqueles encontrados para os núcleos metálicos fundidos, pinos préfabricados metálicos e cerâmicos; II - estes mesmos pinos de fibra mostram menos falhas desfavoráveis dos que os demais sistemas de pinos e núcleos. Revisaram a literatura, selecionaram artigos segundo critérios de inclusão/exclusão, extraíram dados e realizaram análises estatísticas para discussão dos resultados. Observou-se que os núcleos metálicos fundidos apresentaram valores de carga para falha mais elevada do que os pinos de fibra, enquanto que os pinos cerâmicos demonstraram os valores mais baixos. Falhas favoráveis foram significativamente mais comuns com os 
pinos de fibra, do que utilizando os pinos metálicos pré-fabricados e núcleos metálicos fundidos.

Para que se obtenha maior sucesso clínico, GOODACRE ${ }^{28}$, em 2004, apresentou algumas considerações no tratamento de dentes comprometidos tratados endodonticamente. As coroas só aumentam a longevidade clínica de dentes posteriores tratados endodonticamente comparado aos dentes anteriores. Nestes últimos dentes as coroas só estariam indicadas quando a integridade estrutural ou a cor destes não permitem outras formas mais conservadoras de tratamento. O único propósito de utilização de pinos é a retenção de um núcleo necessário para o suporte e retenção de uma coroa ou prótese. Os pinos deveriam estender-se apicalmente até o comprimento onde permanecesse $5 \mathrm{~mm}$ de guta-percha remanescente para um selamento apical adequado. Diâmetros longos de pinos aumentam o risco de fratura e perfuração radicular. Uma férula deveria ser criada por uma coroa ou prótese envolvendo no mínimo 1.5-2.0 mm de estrutura dentária paralela apical ao núcleo.

MORGANO; RODRIGUES; SABROSA ${ }^{61}$, em 2004, afirmaram que a orientação mais comumente aceita para a férula é uma altura mínima de 1.52.0mm de estrutura dentária intacta acima da margem coronária por toda circunferência do preparo dentário. Na impossibilidade de confecção de uma férula sobre dentina remanescente deve-se confeccionar um contra bisel ao redor do preparo para que haja um núcleo fundido com um colar metálico 
que circunde o dente simulando uma férula. Caso a estrutura dentária remanescente ainda assim não for suficiente para a confecção deste bisel, indica-se o aumento de coroa clínica ou uma extrusão ortodôntica para exposição de estrutura dentária adicional. Consideram ainda que quando uma férula adequada não puder ser obtida a melhor opção é a extração do dente com substituição prótese convencional ou implanto suportada.

TERRY $^{88}$, em 2004, comenta que a utilização do sistema de pinos reforçados por fibra com um núcleo direto em resina composta é uma alternativa viável na restauração do espaço intra-radicular. Citou-se as seguintes vantagens da técnica: ausência da fase laboratorial, consulta única, material livre de corrosão, taxas de fraturas radiculares insignificantes, retratamento atraumático, superfícies adesivas microretentivas que aumentam a retenção, conservação de estrutura dentária, propriedades biomecânicas similares as do tecido dentário e nenhum efeito negativo sobre a estética. Como desvantagens a técnica apresenta a necessidade de um cuidadoso protocolo adesivo e a manutenção de um rol de materiais de reforço. Características ideais para a seleção de um sistema de pino e núcleo foram abordadas como: máxima retenção do pino e estabilidade do núcleo, componente anti-rotacional inerente pela utilização de uma férula de 2mm ao redor de estrutura dentária sadia, mínima remoção de estrutura dentária, adaptação morfológica intra-radicular, ótima estética, resistência inerente às falhas radiculares catastróficas, ausência de corrosão, pinos com módulo de elasticidade similar ao da dentina, materiais restauradores com 
resistências flexurais e tensionais similares as da estrutura dentária e que utilize um sistema com adesão ininterrupta.

TORBJÖNER; FRANSSON ${ }^{90}$ fizeram, em 2004, uma revisão de literatura a respeito dos fatores biomecânicos que interferem nos resultados do tratamento protético de dentes estruturalmente comprometidos, principalmente sobre aqueles tratados endodonticamente. A partir de artigos encontrados numa pesquisa do PUBMED/MEDLINE, entre 1970 e 2003, reportaram os seguintes fatores: falhas técnicas na conexão de próteses fixas são freqüentemente provocadas por fraturas de fadiga; os pinos, cimento e a reconstrução estão sujeitos a estresse provocado por forças oclusais e a falha por fadiga poderá ocorrer no ponto mais fraco ou no local onde ocorrer à sobrecarga máxima; o ponto mais fraco freqüentemente se localiza na conexão com dentes tratados endodonticamente restaurados com pinos e núcleos. Concluem que o desenho oclusal da prótese é provavelmente mais importante para a sobrevivência de dentes tratados endodonticamente estruturalmente comprometidos do que o tipo de pino utilizado.

\section{2 - Estudos laboratoriais}

Os achados obtidos a partir de estudos laboratoriais sobre 0 tratamento com pinos e núcleos podem oferecer alguma orientação, porém com baixo nível de evidências, uma vez que as complexas condições intraorais (Ex: padrões de carga, influência da umidade) são impossíveis de 
serem simuladas in vitro ${ }^{90}$. Nem por isso deixam de ter sua validade e são importantes para uma triagem de técnicas e materiais antes de testes in vivo.

Procurando uma razão para a maior fragilidade de dentes tratados endodonticamente comparados aos dentes vitais, HELFER; MELNICK; SCHILDER ${ }^{32}$ em 1972, quantificaram o conteúdo de água dentinário em intervalos de tempo variados pré-determinados, para demonstrar qualquer alteração de umidade após a extirpação pulpar de dentes de cães. A extirpação pulpar foi realizada em dentes do lado direito e os dentes do lado esquerdo permaneceram intactos como controle. Após a extirpação os canais fora secos e selados com cimento de fosfato de zinco. Seis leituras foram feitas no intervalo de 24 semanas. Ao final do período a saliva dos cães foi recolhida para simular a umidade do ambiente oral após a extração dos dentes. Os espécimes constituíram de porções da estrutura dentária do terço cervical. O conteúdo total de água foi determinado por dois parâmetros caracterizados em água livre e água presa. O primeiro parâmetro foi determinado gravimetricamente (o espécime é pesado antes e depois de ser submetido ao calor e a diferença de peso do mesmo entre os períodos determina o conteúdo de umidade) e o segundo por uma análise de diferencial térmico (a partir de efeitos do calor, registrados em função da temperatura ou tempo, a substância é aquecida a uma intensidade uniforme, e o que é registrado fora da câmara de aquecimento é um termograma que é uma curva de aquecimento ou resfriamento que reproduz graficamente o conteúdo total de umidade dos tecidos calcificados). Os resultados 
revelaram uma redução de $9 \%$ da umidade em tecidos calcificados de dentes despolpados comparados aos vitais.

Em 1972, STANDLEE et al $^{86}$. compararam três tipos de pinos considerando o desenho, o método de inserção, o comprimento e a habilidade de cada um transmitir forças aos tecidos de suporte. A avaliação foi realizada através da análise foto-elástica de estresse. Os tipos de pinos analisados foram os paralelos lisos, os cônicos (ambos com $1.4 \mathrm{~mm}$ de diâmetro) e os rosqueáveis (com $1.5 \mathrm{~mm}$ de diâmetro), sendo todos preparados com comprimentos de 4,7 e $10 \mathrm{~mm}$. Foram cimentados com fosfato de zinco em condutos artificiais preparados com as dimensões aproximadas dos incisivos centrais superiores $(13 \mathrm{~mm})$ prolongando-se 4 $\mathrm{mm}$ acima do preparo. Sobre os núcleos foram cimentadas coroas de prata que receberam cargas compressivas tangenciais e de cisalhamento. Pinos rosqueáveis apresentaram a melhor distribuição de estresse em comprimentos curtos, porém geraram altos níveis de estresse quando rosqueados. Pinos cônicos apresentaram efeito de cunha e produziram os valores mais altos de concentração de estresse coronal. Pinos paralelos produziram altos níveis de estresse apical.

Com o objetivo de avaliar a resistência de incisivos centrais superiores, TRABERT; CAPUTO; ABOU-RASS ${ }^{91}$, em 1978, fizeram um estudo com 207 dentes hígidos, divididos em três grupos: gl- sem nenhum tratamento; gll- tratamento endodôntico com guta-pecha; glll- tratamento 
endodôntico e restauração com pino paralelo de aço inox. Cada grupo foi dividido em subgrupos com raízes de 11, 13 e 15mm $\pm 0,95 \mathrm{~mm}$. O diâmetro dos preparos na junção cemento-esmalte foi de 1.40 e $1.80 \mathrm{~mm}$. Os dentes foram colocados em blocos de acrílico até $2 \mathrm{~mm}$ apicais a junção cementoesmalte e foi simulado um ligamento periodontal artificial com silicona. Um analisador de impacto foi especialmente desenhado para determinar os resultados. Dos 207 dentes, 128 forneceram dados para análise de energia absorvida no impacto durante a fratura. Por não ter fraturado durante a prova, o restante dos dentes não foram incluídos. Dos dentes analisados, somente sete mostraram fratura coronária e o restante variou entre fraturas horizontais ou oblíquas da raiz. Não houve diferença estatisticamente significativa entre os dentes tratados ou não endodonticamente. Também não se encontrou correlação significativa entre o tipo e a localização da fratura comparados aos valores de energia de impacto absorvida. O aumento do comprimento radicular elevou a resistência à fratura. O grupo III mostrou resistência significativamente maior à fratura durante o impacto. Os pinos com 17,5mm de comprimento ofereceram menor resistência durante o impacto se comparados com os de $12,7 \mathrm{~mm}$.

GUZY; NICHOLLS ${ }^{31}$, em 1979, compararam a resistência à fratura de dentes tratados endodonticamente com e sem pinos cimentados. Utilizaram 59 incisivos centrais superiores e caninos inferiores tratados endodonticamente divididos em quatro grupos: caninos com e sem pinos, e incisivos com e sem pinos. Nos grupos com pinos, a obturação foi removida 
até $5 \mathrm{~mm}$ do ápice e pinos pré-fabricados metálicos (Endo-Post) foram cimentados com cimento de fosfato de zinco. Os pinos foram cortados $1 \mathrm{~mm}$ abaixo do acesso endodôntico, que foi restaurado com silicato. Os dentes foram fixados (2mm abaixo da junção cemento-esmalte) em blocos de resina acrílica, sendo aplicada silicona de condensação sobre a raiz para simular o ligamento periodontal. Forças compressivas foram aplicadas sobre os dentes através de uma máquina de ensaios universal a um ângulo de $130^{\circ}$. Esta angulação de carga de $130^{\circ}$ foi escolhida para simular o ângulo de contato encontrado em padrões oclusais de Classe I entre dentes anteriores superiores e inferiores. A velocidade de carga foi de $5 \mathrm{~cm} / \mathrm{min}$. Não houve diferença estatisticamente significativa no padrão ou localização da fratura (58 dentes fraturaram no terço médio ou cervical da raiz) nem na resistência à fratura entre os dentes com e sem pinos. Como as falhas iniciaram-se na face vestibular ou lingual das raízes, deduziram que o pino, pela sua posição, recebe estresse mínimo, reforçando muito pouco a raiz sob cargas externas. Conseqüentemente, quanto mais longo o diâmetro vestíbulolingual da raiz, maior sua resistência à fratura.

TJAN; WHANG ${ }^{89}$, em 1985, pesquisaram a resistência à fratura de raízes de incisivos superiores com diferentes espessuras de parede dentinária vestibular. Quarenta núcleos metálicos fundidos foram confeccionados sobre raízes com remanescente dentinário na entrada do canal variável em espessuras de 1,0 mm, 2,0mm, 3,0mm e 1,0mm com um término cervical em chanfrado. Um carregamento tangencial de compressão 
foi aplicado sobre a superfície palatina dos núcleos a uma velocidade de $0.05 \mathrm{inch} / \mathrm{min}$ ou $0,12 \mathrm{~mm} / \mathrm{min}$ (uma polegada $=2,54 \mathrm{~cm}$ ). Os corpos de prova foram posicionados numa angulação de $30^{\circ}$ em relação ao plano horizontal. As médias, em libras (453 g), convertidas para Kg, foram as seguintes: gl- $48.7(22,06 \mathrm{Kg})$, gll- $47.4(21,47 \mathrm{Kg})$, gllI- $48.8(22,10 \mathrm{Kg})$ e gIV$44.4(19,93 \mathrm{Kg})$. Apesar de não ter havido diferença estatisticamente significativa entre os grupos, às raízes com 1,0mm de espessura de parede dentinária vestibular foram mais propensas à fratura do que aquelas com $2 \mathrm{~mm}$ e $3 \mathrm{~mm}$. A adição de um colar metálico ao redor do término cervical não aumentou a resistência à fratura radicular.

No mesmo ano, TROPE; MALTZ; TRONSTAND ${ }^{92}$ realizaram uma pesquisa com o objetivo de comparar a resistência à fratura de dentes tratados endodonticamente seguindo diferentes formas de tratamento. A amostra consistiu em 64 incisivos superiores hígidos, de dimensões semelhantes (com até $1 \mathrm{~mm}$ de diferença). Foi feito um acesso cavitário de $2 \mathrm{~mm}$ de profundidade, por $2 \mathrm{~mm}$ de largura na superfície lingual dos dentes. Os condutos radiculares foram instrumentados até a lima 70 e obturados com guta-percha e cimento de Grossman. Após 72 horas, os dentes forma tratados da seguinte maneira: gl- restauração do acesso com resina composta (Concise); gll- restauração com resina composta precedida de condicionamento ácido; glll- restauração do acesso cavitário com resina composta precedida de condicionamento ácido deixando um espaço para o pino (comprimento de $10 \mathrm{~mm}$ e diâmetro de $25 \mathrm{~mm}$ ) preenchido com algodão, 
gIV- preenchimento da cavidade com resina composta, criação de espaço para o pino com broca de 1,25mm de diâmetro (Parapost) até $10 \mathrm{~mm}$ de comprimento abaixo da junção cemento-esmalte sem a restauração do mesmo; gV- espaço para o pino como no anterior, sendo o acesso cavitário e o espaço para o pino preenchido com resina composta sem ataque ácido; gVl- espaço para o pino criado como nos grupos anteriores, com cimentação de pino de aço com cimento de fosfato de zinco e restauração do acesso cavitário com resina composta; gVII- espaço padrão para o pino condicionado com ácido, preenchido com resina sendo a cavidade completada com algodão; gVIII- espaço padrão para o pino e cavidade foram condicionados com ácido e um pino de aço foi posicionado com resina composta, assim como a cavidade restaurada com o mesmo material. Os dentes foram submetidos à força compressiva incidindo na altura do cíngulo, num ângulo de $50^{\circ}$ em relação ao seu longo eixo. A força necessária para fraturar cada dente foi registrada e os resultados analisados comparativamente. Um dente foi perdido em cada um dos grupos II, III, VI e VIII durante o experimento. $\mathrm{O}$ modo de fratura foi similar para todos os grupos. No entanto, houve variações consideráveis nos valores de resistência à fratura. As médias, em $\mathrm{Kg}$, foram as seguintes: gl- $146 \pm 31.94$; gll- $149.86 \pm 19.64 ;$ glll- $153.21 \pm 23.22 ;$ gIV- $85.58 \pm 28.41$; gV- 92.30 $\pm 25.93 ;$ gVl- $121.17 ;$ gVII $-133.90 \pm 26.86$ e gVIII-: $123.47 \pm 14.18$. Concluíram que: o preparo do espaço para o pino enfraqueceu significativamente dentes tratados endodonticamente; o pino não reforçou significativamente os mesmos dentes; nenhum dos métodos utilizados para 
restaurar dentes com espaço para o pino reforçou estes quando comparados aos espécimes onde o espaço não foi preparado; o condicionamento ácido seguido de restauração com resina composta aumentou a resistência dos dentes mais do que os outros métodos restauradores, mostrando ser o método mais eficaz de restaurar dentes jovens com apicificação incompleta ou com raízes alargadas e dentina radicular delgada.

REEH; MESSER; DOUGLAS ${ }^{73}$, em 1989, verificaram o que poderia contribuir mais para a diminuição de resistência de um dente íntegro: procedimentos endodônticos ou restauradores. Para tanto uma carga oclusal não destrutiva foi aplicada sobre segundos pré-molares intactos extraídos. Sobre as superfícies de esmalte vestibulares e palatinas, logo acima da junção cemento-esmalte, foram unidos "strain gauges" (medidores de deformação) e os dentes foram montados em anéis de nylon deixando $2 \mathrm{~mm}$ de raiz exposta. Sob uma carga controlada, cada dente foi carregado com uma intensidade de carga de $37 \mathrm{~N}(3,77 \mathrm{Kgf})$ por segundo por $3 \mathrm{~s}$ e descarregado na mesma intensidade num sistema hidráulico de alça fechada para medir a dureza. Uma curva de estresse/ deformação foi gerada para cada distorção antes e depois da modificação de cada dente. A rigidez da cúspide, como uma medida de resistência do dente, foi avaliada em cada uma de duas séries de procedimentos realizados seqüencialmente: 1(a) dente inalterado, (b) preparo do acesso, (c) instrumentação, (d) obturação e (e) preparo de cavidade MOD; ou 2 (a) dente inalterado, (b) preparo de cavidade oclusal, (c) preparo de cavidade com duas faces, (d) preparo de 
cavidade MOD, (e) acesso, (f) instrumentação e (g) obturação. Os resultados sobre 42 dentes indicaram que os procedimentos endodônticos reduziram apenas $5 \%$ da dureza do dente, enquanto que um preparo de cavidade oclusal reduziu 20\%. O preparo MOD resultou em média numa redução de dureza da cúspide de 63\%. Os procedimentos endodônticos não enfraquecem dentes com cristas marginais intactas.

SORENSEN; ENGELMAN ${ }^{85}$, em 1990, avaliaram a resistência à fratura de dentes tratados endodonticamente restaurados com vários tipos de férulas e quantidades de estrutura coronária. Os dentes foram restaurados com núcleos fundidos e coroas metálicas, ambas cimentadas com fosfato de zinco. A férula foi definida como uma banda metálica que envolvia as paredes da porção coronária remanescente. Foram utilizados 60 incisivos centrais superiores divididos em seis grupos: gl- sem remanescente e raiz enfraquecida; gll- sem remanescente; gllI-preparo em $130^{\circ} \mathrm{com} \mathrm{2,0}$ mm de remanescente e núcleo com contra-bisel; glV- término com 1,0 mm de extensão; gV- término com $1,0 \mathrm{~mm}$ de extensão, mais $1,0 \mathrm{~mm}$ de remanescente; gVI- término com 1,0 mm de extensão, mais 2,0 mm de remanescente com núcleo em contra-bisel. Todos os grupos tiveram a mesma profundidade nos condutos. Após aplicação da carga estática até a falha, as seguintes médias foram obtidas: gl- 29,5 Kg; gll- 29,0 Kg; glll- 35,0 Kg; gIV- 36,3 Kg; gV- 65,3 Kg; gVI- 69,4. Houve uma diferença significativa entre os grupos I, II, III e IV quando comparados com os grupos V e VI. Quanto ao tipo de falha, $25 \%$ delas foram por decimentação e os outros $75 \%$ 
de falhas envolveram fraturas. Os grupos $\mathrm{V}$ e VI só apresentaram falhas por fraturas. O limiar de resistência à fratura foi melhorado em dentes com 1,0 mm de estrutura dentária remanescente acima de términos com 1,0 mm de extensão e preparo das paredes axiais mais paralelo, enquanto que o uso do contra-bisel não foi efetivo. Constatou-se que a espessura das paredes axiais não se mostrou importante na resistência à fratura.

KOVARIK; BREEDING; CAUGHMAN ${ }^{40}$, em 1992, quiseram saber qual o comportamento de caninos restaurados com pinos metálicos e três materiais para núcleo de preenchimento frente a ensaio de fadiga. Os testes foram realizados através de um simulador de mastigação personalizado que aplicou intermitentemente (um ciclo por segundo) uma combinação de forças compressivas e de cisalhamento (75libras/ 33N/ 3,36Kgf) por um milhão de ciclos ou até a identificação de uma falha. A falha foi definida como um deslocamento horizontal (restauração como um todo) de $30 \mu \mathrm{m}$ ou mais e este momento registrado com a quantidade exata de ciclos. Após os testes os dentes foram seccionados e examinados para determinar as causa da falha. Somente o material do núcleo de preenchimento influenciou significativamente na sobrevivência das restaurações. Núcleos de amálgama tiveram os menores índices de falhas seguidos pelas reconstruções em resina composta. Todos os dentes restaurados com coroas sobre núcleos de ionômero de vidro falharam. 
MILOT; STEIN ${ }^{56}$, em 1992, investigaram a influência do bisel na resistência à fratura de dentes artificiais padronizados que simularam incisivos centrais divididos em três grupos de 16. No grupo I foram cimentados núcleos metálicos fundidos (diâmetro variável de $0.8 \mathrm{~mm}$ na porção apical a $2.8 \mathrm{~mm}$ na porção cervical). No grupo II, foram utilizados pinos Para-Post Plus $n^{\circ} 5$ (1,15mm de diâmetro). No grupo III, foram utilizados pinos Flexi-Post no 1 (1,1mm de diâmetro). A porção coronária dos grupos II e III foi reconstruída com ionômero de vidro reforçado com prata. Metade dos dentes de cada grupo foi preparada com um término em chanfrado e metade recebeu um chanfro largo ( $1 \mathrm{~mm}$ de diâmetro) e bisel. Sobre os núcleos foram cimentados coroas metálicas. Forças compressivas foram aplicadas sobre a superfície palatina à velocidade de $50 \mathrm{~mm} / \mathrm{min}$ e com inclinação de $120^{\circ}$ em relação ao longo eixo radicular. Os espécimes com bisel de $1 \mathrm{~mm}$ demonstraram maior resistência à fratura, além de apresentarem menor quantidade de fraturas verticais. Em relação ao tipo de pino, não se observou efeito significativo sobre a resistência final.

No ano de 1992, SEDGLEY; MESSER ${ }^{80}$ analisaram as propriedades biomecânicas de vinte e três dentes tratados endodonticamente e seus pares vitais contra-laterais. No estudo foram testadas as seguintes variáveis: resistência à tração, módulo de elasticidade, dureza e resistência à fratura. A análise estatística não revelou nenhuma diferença significativa entre os dois grupos. Baseados nas similaridades das propriedades biomecânicas encontradas entre dentes vitais e não vitais, constatou-se que o tratamento 
endodôntico não torna o dente mais frágil. Fatores como perda de estrutura dental por cárie, acesso endodôntico, instrumentação endodôntica, traumas e preparos cavitários foram considerados muito mais contribuintes para a fragilidade do dente.

No trabalho de HUANG, SCHILDER; NATHANSON ${ }^{37}$, publicado em 1992, foram analisadas espécimes de dentina, entre dentes vitais e tratados endodonticamente, com o objetivo de determinar se haveria diferença significativa entre as propriedades mecânicas da dentina entre ambos. Tais propriedades foram avaliadas depois das amostras serem submetidas a testes de compressão, tração e impacto. Os resultados deste estudo revelaram que a desidratação após o tratamento endodôntico não enfraqueceu a dentina, já que não houve diferença estatisticamente significativa na resistência à compressão e tração dos dentes despolpados contrapostos aos dentes vitais.

Ainda em 1992, TROPE; RAY ${ }^{93}$ avaliaram a resistência à fratura de 48 caninos superiores e inferiores tratados endodonticamente seguindo diferentes técnicas: gl- condutos instrumentados e obturados com cimento Ketac Endo; gll- condutos sem instrumentação; glll- condutos instrumentados e não obturados, gIV- condutos instrumentados e obturados com cimento de Roth's 801 pela técnica de condensação lateral. As raízes foram preparadas para o teste através de um seccionamento de $2 \mathrm{~mm}$ de profundidade da superfície lingual criando um entalhe para a aplicação da 
força numa angulação de $15^{\circ}$. Dentes que tiveram os condutos radiculares instrumentadas foram significativamente menos resistentes do que outros com canal radicular não instrumentado.

LUI ${ }^{45}$, em 1994, avaliou a eficiência da transmissão de luz de pinos fototransmissores (LUMINEX). Neste estudo, a profundidade de cura de uma resina composta fotopolimerizada dentro de canais radiculares artificiais através de pinos plásticos transmissores de luz foi comparada ao método convencional de fotopolimerização. Seis tamanhos de pinos com diâmetros de $1.05 \mathrm{~mm}, 1.20 \mathrm{~mm}, 1.35 \mathrm{~mm}, 1.50 \mathrm{~mm}, 1.65 \mathrm{~mm}$, e $1.80 \mathrm{~mm}$ foram investigados. A profundidade de cura da resina composta foi determinada por um indicador digimático, que é um instrumento de mensuração de deslocamento com alta precisão. A profundidade de cura da resina foi interpretada a partir de valores de deslocamento da ponta medidora, em contato com a superfície avaliada, registrados pelo aparelho. Quanto maior o grau de polimerização maior o valor de deslocamento registrado pelo aparelho. Em geral, os pinos com maior diâmetro ofereceram maior profundidade de cura. Existiu diferença significativa na profundidade de cura entre o grupo controle (sem pino) e todos os tamanhos de pinos avaliados e também entre todos os diâmetros (com exceção dos pinos de $1.35 \mathrm{~mm}$ e 1.50mm). Com estes pinos fototransmissores foi possível encontrar uma profundidade de cura que ultrapassou $11 \mathrm{~mm}$. 
MARTINS ${ }^{54}$, em 1995 avaliou a resistência à fratura de raízes debilitadas preenchidas com materiais adesivos. Dentes uni-radiculares com dimensões semelhantes tiveram suas coroas clínicas removidas e suas raízes preparadas para simular um enfraquecimento. Os desgastes foram realizados da seguinte maneira: no terço coronário, foi utilizada uma ponta diamantada esférica $\mathrm{n}^{\circ} 3018 \mathrm{HL}$ (haste longa) até a profundidade de $4 \mathrm{~mm}$ de maneira permanecer paredes radiculares com $0.5 \mathrm{~mm}$ de espessura; no terço médio utilizou-se uma ponta diamantada esférica nº 3017 HL para o desgaste até a profundidade de $6 \mathrm{~mm}$; o desgaste do terço apical foi realizado com uma ponta diamantada esférica $n^{0} 1016$, até uma profundidade de $8 \mathrm{~mm}$. As raízes empregadas como controle positivo foram preparadas para receber um núcleo metálico fundido (NMF), utilizando-se broca de Peeso $n^{\circ} 2$, com a qual desgastou-se internamente a raiz até deixá-la com forma cônica, atingindo-se profundidade de $2 / 3$ do comprimento radicular. Foram utilizadas 49 raízes divididas em sete grupos: gl- sem enfraquecimento (controle positivo); gll- enfraquecimento com NMF morfológico (controle negativo); grupo III preenchimento com ionômero de vidro tipo II modificado (Chelon Silver) gIV- preenchimento com ionômero de vidro tipo III (Ketac-Bond); gV- preenchimento com ionômero de vidro fotoativado (Vitremer); gVI- preenchimento com sistema adesivo e resina composta Herculite XRV e gVII- preenchimento com sistema adesivo e resina composta-Z-100. A inserção dos materiais nas raízes foi auxiliada por cones de guta-percha principal ( $n^{\circ}$ 80). A polimerização dos materiais fotoativados foi realizada em camadas subseqüentes. Com um novo conduto 
criado, empregou-se uma ponta diamantada tronca cônica até o comprimento de 2/3 da raiz. Posteriormente foram confeccionados núcleos metálicos fundidos, utilizando-se liga de $\mathrm{Cu}-\mathrm{Al}$, cimentados com fosfato de zinco e uma carga estática de $5 \mathrm{Kg}$ por dez minutos. Os corpos de prova foram mantidos em estufa a $37^{\circ} \mathrm{C}$, umidade relativa de $100 \%$ por 24 horas e submetidos ao teste de resistência à compressão em máquina de ensaio universal. As médias dos resultados (Kgf) e respectivos desvios padrão foram: gl- 202.63(1,66); gll- 125.55 (13,38); gllI- 183.53 (14,67); gIV- 107.68 (10,07); gV- 205.91 (4,97); gVI- 194.02 (11,17); gVII- 236,81 (21,99). Concluiu-se que, entre os materiais testados, a resina composta Z-100 obteve o melhor desempenho, inclusive em relação ao controle positivo; o ionômero Vitremer, a resina composta XRV e o Chelon-Silver apresentaram resultados semelhantes entre si e ao controle positivo; o ionômero KetacBond teve comportamento desfavorável em relação a todos os outros e semelhantes ao controle negativo.

GOLDSTEIN; HUDIS; WEINTRAUB ${ }^{27}$, em 1996, compararam quatro técnicas de aplicação de cimento à interface dente-pino. O objetivo foi verificar qual técnica de cimentação proporcionaria uma camada mais uniforme de cimento e a interferência desta na retenção do pino. Quarenta dentes uni-radiculares extraídos foram tratados endodonticamente e tiveram suas porções coronárias removidas. Criou-se espaço para que o conduto recebesse um NMF em prata-paládio (diâmetro de $1.27 \mathrm{~mm}$ ) cimentado com fosfato de zinco. As técnicas de cimentação foram: lentulo espiral, sonda 
endodôntica, pontas de papel e aplicação direta do cimento ao núcleo. Os núcleos foram cimentados com pressão digital até o escoamento do cimento e a seguir foi aplicada uma carga constante de 1,5 $\mathrm{Kg}$ por 15 minutos. Os dentes foram seccionados no seu longo eixo para visualização da presença de bolhas em três áreas: oclusal, apical e pelo corpo do núcleo. Os resultados mostraram que a técnica utilizando a broca lentulo foi a mais adequada por eliminar a presença de bolhas no cimento.

ISIDOR; ÖDMAN; BRØNDUM ${ }^{38}$,em 1996, avaliaram a resistência à fadiga de dentes bovinos restaurados com pinos pré-fabricados de fibra de carbono, núcleo de preenchimento em resina composta autopolimerizável e coroa total metálica. Após atingirem 260.000 ciclos de carga (250N), numa freqüência de $2 \mathrm{~Hz}, 9$ dos 14 dentes falharam, sendo 4 foram por fratura longitudinal incompleta. Os resultados revelaram um melhor comportamento do pino pré-fabricado de fibra de carbono, seguido pelo pino pré-fabricado metálico e núcleo fundido, com diferença estatística entre todos eles.

SAUPE; GLUSKIN; RADKE78, em 1996, verificaram a importância de se reforçar raízes internamente antes destas receberem núcleos metálicos fundidos em ouro. Quarenta incisivos centrais superiores tiveram suas coroas removidas preservando um remanescente de 1 a $2 \mathrm{~mm}$ acima da junção cemento-esmalte. Os canais foram instrumentados até a lima $n^{\circ} 35$ e obturados com cimento sem eugenol (AH 26). A simulação do dano estrutural foi feita através de desgastes com $8 \mathrm{~mm}$ de profundidade e 
paredes dentinárias remanescentes com espessura variável entre 0.5 a 0.75mm. Os dentes foram reabilitados de duas maneiras: núcleos morfológicos ou reforço com resina e núcleos. Para ambos os tipos de tratamento houve uma variação da metade dos dentes na criação de um colar metálico de $2 \mathrm{~mm}$ com três graus de angulação como forma de resistência à fratura. Todos os núcleos foram cimentados com cimento resinoso (Enforce) e submetidos à aplicação de uma carga constante de $2 \mathrm{~mm} / \mathrm{min}$ na face lingual dos dentes. A resistência dos dentes restaurados com resina e núcleo foi estatisticamente superior que aquela dos núcleos morfológicos. Não existiu diferença significativa entre os núcleos com colar metálico e os sem colar metálico dentro do mesmo sistema. A retenção dos núcleos cimentados com cimentos não adesivos tem a desvantagem de depender exclusivamente do embricamento mecânico, além de haver uma concentração de estresse na interface dentina-cimento-núcleo. Já os cimentos resinosos apresentam adesão química à dentina e ao pino, além do módulo de elasticidade mais próximo ao da dentina. A utilização de um pino fototransmissor (Luminex) facilitou a restauração de dentes tratados endodonticamente com paredes delgadas aumentando sua resistência à fratura se comparada àquela oferecida pelo NMF morfológico convencional.

COHEN et al. ${ }^{17}$, em 1997 submeteram a fadiga incisivos e prémolares restaurados com 5 tipos de pinos pré-fabricados metálicos e 4 materiais para núcleo de preenchimento. $\mathrm{O}$ ensaio compreendeu a aplicação de impactos de carga (22N ou 2,04Kgf) numa freqüência de 3 repetições por 
segundo num total de quatro milhões de ciclos ou até que a falha ocorresse (fratura do dente, núcleo ou pino). Não houve diferença estatisticamente significativa entre os pinos, fato não ocorrido para o material dos núcleos. A resina composta híbrida reforçada com titânio (Ti-Core) e o amálgama resistiram significativamente uma maior quantidade de ciclos do que os núcleos em ionômero de vidro.

No mesmo ano, COHEN et al. $^{18}$ analisaram a resistência à carga estática de três materiais para confecção de núcleo de preenchimento suportados ou não por um pino. Os materiais testados foram uma resina composta reforçada com titânio (com pino-1030,4N/ 105,14 Kgf; sem pino950,9N/ 97,03Kgf), amálgama (com pino-771,4N/ 78,71Kgf; sem pino628,6N/ 64,17Kgf), e ionômero de vidro híbrido (com pino-706,7N/ 72,11Kgf; sem pino-597,8N/ 61Kgf). Os grupos restaurados com resina composta foram semelhantes entre si e superiores aos outros materiais que não se diferenciaram. Apesar de não se ter utilizado coroas sobre os espécimes, o resultado deste estudo, onde a carga foi aplicada diretamente sobre o núcleo, pode ser relevante pelo fato da resistência ser testada numa condição mais severa.

Em 1997, MARCHI ${ }^{51}$, avaliou a resistência à fratura de raízes de dentes anteriores, reconstruídas morfologicamente com sistemas adesivos associados a pinos intra-radiculares. As raízes de 76 dentes uni-radiculares, entre incisivos centrais e caninos superiores, foram separadas das coroas e 
divididas de acordo com seus volumes, em pequenas, médias e grandes. Foram divididas por sorteio entre hígidas ou aquelas que simulariam uma raiz clinicamente enfraquecida. Trinta e oito raízes, entre debilitadas e hígidas, foram preparadas para receberem núcleos metálicos fundidos enquanto o restante recebeu pinos pré-fabricados. Para simular o enfraquecimento radicular inicialmente se utilizou a ponta diamantada esférica $\mathrm{n}^{\circ} 1016$ até a profundidade de 8mm. Um segundo desgaste foi feito com a ponta diamantada $n^{\circ} 3017 \mathrm{HL}$ até o terço médio na profundidade de $6 \mathrm{~mm}$. O desgaste do terço coronário foi realizado com a ponta diamantada $3018 \mathrm{HL}$ até a profundidade de $4 \mathrm{~mm}$ e deixou paredes dentinárias com 0,5mm de espessura controladas por espessímetro. O preenchimento das raízes debilitadas com sistema adesivo (Scotchbond Multipurpose Plus) e resina composta (Z-100) foi auxiliado por um cone principal de guta-percha $n^{\circ} 80$ vaselinado. A inserção da resina foi feita através de incrementos de aproximadamente $1,5 \mathrm{~mm}$, fotopolimerizados por 40 segundos. Os preparos para NMF e pino pré-fabricado foram realizados da mesma maneira nas raízes hígidas e nas debilitadas reconstruídas com resina. Após a cimentação dos núcleos metálicos fundidos e dos pinos pré-fabricados de aço com cimento de fosfato de zinco as raízes foram incluídas em blocos acrílicos. Os corpos de prova foram mantidos em estufa a $37^{\circ} \mathrm{C}$ e umidade relativa até o momento do teste numa máquina de ensaios universal sob um ângulo de carga de $135^{\circ}$ em relação ao longo eixo radicular. Verificou-se uma influência significativa das variáveis: volume e condição radicular e tipo de pino intra-radicular nos valores de resistência. Também se notou 
diferença significativa das interações volume radicular vs condição da raiz e condição da raiz vs tipo de pino intra-radicular. Em relação ao fator volume de raiz, as médias (Kgf) foram: grande-22,08; médio-18,56; pequeno-16,48. O volume grande apresentou diferença em relação ao médio e ao pequeno. Em relação ao tipo de pino houve diferença estatisticamente significativa entre as médias (Kgf) apresentadas pelo pré-fabricado $(20,27)$ e NMF $(17,81)$. Referindo-se à interação entre volume da raiz vs condição das raízes as médias foram: grande x hígida $(30,33)$; médio x hígida $(23,83)$; pequeno x hígida $(19,99)$; grande $x$ debilitada $(13,83)$; média $\times$ debilitada $(13,29)$; pequena $x$ debilitada $(12,97)$. As raízes hígidas apresentaram diferença significativa se comparadas às debilitadas. Para a interação condição da raiz x tipo de pino as médias foram: hígido x pino pré-fabricado $(27,71)$; hígido x $\operatorname{NMF}(21,72)$; debilitado x $\operatorname{NMF}(13,91)$; debilitada x préfabricados $(12,83)$ apresentando os dois primeiros diferença significativa. Concluiu-se que a espessura de tecido dentinário remanescente ao redor do pino ou NMF intra-radicular está diretamente relacionada com resistência à fratura radicular; pinos pré-fabricados que apresentam roscas foram mais resistentes à fratura do que núcleos metálicos fundidos cônicos de superfície lisa; a resina composta não foi capaz de recuperar a capacidade de resistência à fratura.

MENDOZA et al. ${ }^{55}$, em 1997, avaliaram a resistência à fratura de raízes (caninos inferiores) fragilizadas no terço cervical (1mm de espessura dentinária) variando o material restaurador de reforço radicular. Foram 
testados dois cimentos resinosos (Panavia e C\&B Meta-bond), uma resina composta (Z-100) e como controle um cimento de fosfato de zinco. Em todos os grupos foram cimentados pinos metálicos pré-fabricados a uma profundidade de $8 \mathrm{~mm}$. Previamente a aplicação da força, os corpos de prova sem a presença de qualquer coroa foram submetidos a termociclagem. A maioria dos corpos de prova sofreu fratura radicular vertical. O cimento Panavia ofereceu a maior resistência entre os grupos, significativamente diferente apenas do grupo cimentado com fosfato de zinco. Observaram a ocorrência de um alto desvio padrão e como forma de minimizar este problema os mesmos sugeriram uma seleção de dentes mais criteriosa.

Em 1998, FREEMAN et al. ${ }^{26}$, buscaram determinar o número mínimo de ciclos de carga necessário para causar a falha preliminar em dentes restaurados com três diferentes tipos de núcleos, pinos e coroas totais metálicas. Após a constatação da falha preliminar, aplicou-se mais 100.000 ciclos com posterior banho em fucsina e secção dos espécimes para análise da micro-infiltração. Trintas incisivos centrais superiores foram divididos em três grupos: um restaurado com pino metálico pré-fabricado paralelo, núcleo de resina composta, outro restaurado com pino metálico pré-fabricado cônico, núcleo de resina composta, e o último com núcleo fundido. Tanto os pinos quanto às coroas foram cimentados com fosfato de zinco. Observaram que a falha preliminar, detectada por 'strain gauge' sobre as coroas, ocorreu com um baixo número de ciclos (menos que 800 ciclos) e foi imperceptível 
clinicamente para todos os grupos. Todos os grupos também tiveram índices de micro-infiltração e em alguns casos esta alcançava a superfície do pino.

MARTINEZ-INSSUA et al. ${ }^{53}$, em 1998, compararam a resistência à fratura de pré-molares restaurados com pinos de fibra de carbono e núcleos em resina composta com núcleos metálicos fundidos. Os dentes restaurados com núcleos metálicos fundidos registraram média de resistência à fratura $(202.7 \pm 125.0 \mathrm{Kg})$ significativamente mais alta do que aqueles restaurados com pinos de fibra de carbono $(103.7 \pm 53.1 \mathrm{Kg})$. Os pinos metálicos proporcionaram fraturas radiculares com prognóstico duvidoso de reparação, enquanto que no grupo com pinos de fibra, a fratura no núcleo de preenchimento permitiria reparo. Tais valores de carga encontrados, mesmo os mais baixos obtidos com os pinos de fibra de carbono, raramente acontecem clinicamente.

Através de um carregamento tangencial a 45, ASMUSSEN; PEUTZFEDT; HEITMANN ${ }^{8}$ verificaram em 1999, propriedades mecânicas como rigidez, limite elástico e resistência de pinos cerâmicos (BIOPOST, CERPOST), de titânio (PCR), e fibra de carbono (Composipost). Tais propriedades foram determinadas e registradas a partir da relação entre a força aplicada e a curva de deflexão apresentada pelo pino. Os pinos cerâmicos foram muito rígidos e resistentes sem nenhum comportamento plástico. O pino de titânio apresentou resistência semelhante, embora com 
menor rigidez. Já o pino de fibra de carbono obteve os valores mais baixos para as três propriedades avaliadas.

MANNOCCI; FERRARI; WATSON ${ }^{49}$, em 1999, avaliaram o comportamento de dentes restaurados com diferentes pinos intra-radiculares após aplicação de carga intermitente em meio úmido. Os dentes foram restaurados com pinos de fibra de quartzo ( $g \mathrm{l})$, fibra de carbono (gll), zircônia (glli) e coroa total cerâmica. Os impactos foram aplicados numa frequência de $2 \mathrm{~Hz}$ e com uma carga de $250 \mathrm{~N}$ até que alguma falha fosse detectada ou até 400 mil ciclos. Os modos de falha foram atribuídos como fratura radicular e decimentação do pino, fratura radicular e do pino, fratura radicular e fratura da coroa. Os pinos de fibra de quartzo e fibra de carbono reduziram ao mínimo o risco de fraturas radiculares e quando ocorreram foram consideradas favoráveis.

REAGAN et al. $^{72}$, em 1999, desenvolveram um aparelho para ensaios de fadiga ligado a um computador. Durante a aplicação dos impactos mecânicos nos espécimes, foi possível detectar o movimento lateral de 63.5 $\mu \mathrm{m}$ do núcleo através de um transdutor. Tal deslocamento representou uma falha inicial do cimento. Esta informação permitiu que fosse registrado o número máximo de ciclos que um determinado tipo de pino e núcleo resistiu antes do deslocamento. Neste estudo os núcleos em resina composta exibiram maior quantidade de ciclos antes da falha pré-estabelecida do que os demais sistemas de pinos e núcleos testados (pinos metálicos com 
núcleos em amálgama e núcleos metálicos fundidos). Apesar desta maior resistência não ter sido estatisticamente significativa entre os grupos, atribuiu-se a este resultado o fato da resina composta apresentar uma melhor absorção de impactos pelo módulo de elasticidade próximo ao da dentina.

SIRIMAI; RIIS; MORGANO ${ }^{82}$, em 1999, verificaram a resistência à fratura de dentes despolpados restaurados com seis tipos de pinos e núcleos cimentados com diferentes cimentos. Após os ensaios de compressão compararam os modos de fratura entre os grupos. Verificaram que o NMF foi o sistema que alcançou os maiores valores de resistência, porém com $100 \%$ das falhas envolvendo fraturas radiculares. Os pinos metálicos pré-fabricados com núcleos em resina composta apresentaram um percentual de $70 \%$ das falhas correspondendo a fraturas radiculares, enquanto os pinos de fibra trançada de polietileno apresentaram valores de resistência mais baixos, porém com um número significativamente menor de fraturas radiculares verticais.

Em 1999, SOARES ${ }^{84}$, avaliou a resistência à fratura de raízes debilitadas reconstruídas com diferentes sistemas restauradores adesivos e NMF, quando comparadas à raiz hígida com núcleo fundido. Para isso, foram utilizados 56 incisivos centrais e caninos superiores com dimensões semelhantes, os quais foram divididos em quatro grupos: gl- (controle) raiz hígida com NMF; gll- raiz debilitada reconstruída com resina composta 
fotopolimerizável (Z-100); glll- raiz debilitada reconstruída com cimento de ionômero de vidro (Vitremer); gIV- raiz debilitada reconstruída com resina composta autopolimerizável (Bisfill II). Os dentes tiveram suas porções coronárias removidas padronizando-se os remanescentes em $12 \mathrm{~mm}$ de comprimento. Uma seqüência de desgastes foi estabelecida para a simulação de raízes enfraquecidas. O primeiro desgaste, limitado ao terço cervical da raiz, foi realizado com a ponta diamantada esférica $n^{\circ} 3018 \mathrm{HL}$, até $4 \mathrm{~mm}$ de profundidade deixando paredes remanescentes com $0,5 \mathrm{~mm}$ de espessura. O segundo desgaste foi confeccionado com a ponta diamantada esférica $\mathrm{n}^{\circ} 3017 \mathrm{HL}$ até a profundidade de $6 \mathrm{~mm}$. Já o terceiro desgaste com $8 \mathrm{~mm}$ de profundidade foi feito com uma ponta diamantada esférica $\mathrm{n}^{\circ} 1016$. Para os materiais fotopolimerizáveis utilizou-se um pino fototransmissor Luminex $n^{\circ} 4$, deixando um espaço com $8 \mathrm{~mm}$ de comprimento e $1,5 \mathrm{~mm}$ de diâmetro para o pino intra-radicular. As raízes do grupo controle foram preparadas com o alargador $\mathrm{n}^{\circ} 4$ do sistema Luminex. Os corpos de prova foram armazenados por 24 horas em água deionizada e em estufa regulada a $37^{\circ} \mathrm{C}$. Os testes de resistência à fratura foram realizados numa máquina universal de ensaios através de cargas incidindo na face palatina numa angulação de $135^{\circ}$ em relação ao longo eixo radicular. As médias dos resultados (Kgf) e os respectivos desvios padrão por grupo foram: gl- 71,6 (4,84); gll- 40,1 (6,89); gIII- 27,3 (5,41); gIV- 36,2 (4,16). Após análises estatísticas observou-se que nenhum dos sistemas restauradores utilizados foi capaz de recuperar a resistência à fratura da raiz. Não houve diferença entre as resinas auto e fotopolimerizáveis. O cimento de ionômero de vidro 
apresentou os menores valores estatisticamente significativos em relação aos demais grupos em teste.

Avaliando o efeito da férula sobre a resistência à fratura de dentes restaurados com pino pré-fabricado, núcleo de resina composta e coroa total metálica AL-HAZAIMEH; GUTTERIDGE ${ }^{6}$, em 2001, observaram valores mais altos para os incisivos restaurados com um remanescente de $2 \mathrm{~mm}$, porém não estatisticamente significativos quando comparados àqueles sem férula.

BOLHUIS et al. ${ }^{11}$, em 2001, investigaram a resistência à fratura de pré-molares humanos, com $2 \mathrm{~mm}$ de remanescente coronário, restaurado por três tipos de restaurações: com núcleo (Ti-core, Photo Core e Ketac Molar) e sem pino endodôntico, com núcleo e pino (NMF e núcleo em resina composta fotopolimerizável com pino de fibra de sílica) e sem núcleo e pino. Todos os espécimes apresentavam coroas metálicas. Após o carregamento até à fratura numa angulação de $45^{\circ}$, os valores médios de resistência entre os grupos não se mostraram estatisticamente significativos. Considerou-se a confecção de um núcleo sem um pino pode ser uma alternativa ao NMF quando houver pelo menos $2 \mathrm{~mm}$ de férula sobre a estrutura dentária.

No mesmo ano, BONILLA ${ }^{13}$ avaliou a resistência à fratura de raízes amplamente destruídas, reconstruídas morfologicamente ou não com sistemas adesivos e restauradas com núcleos metálicos fundidos ou com 
pinos dentários. Quarenta caninos superiores foram divididos em quatro grupos: gl- raiz íntegra com NMF; gll- raiz amplamente destruída com NMF; glll- raiz amplamente destruída reconstruída com resina composta e NMF; e gIV- raiz amplamente destruída reconstruída com pino dentário. As coroas dentárias foram seccionadas e os condutos obturados. No grupo I, o conduto foi preparado para receber NMF convencional. Já nos grupos II, III e IV, foi executada a seqüência padronizada de desgaste para simular uma raiz amplamente destruída, com espessura de parede dentinária cervical de 0.5mm. No grupo II foram confeccionados núcleos metálicos fundidos. No grupo III as raízes foram reconstruídas com resina composta fotopolimerizável para reconstrução de núcleos (Build-It!), polimerizada através de pino fototransmissor Luminex, criando um novo conduto que foi preparado para receber um NMF. O grupo IV recebeu pinos dentários obtidos a partir de dentes naturais. As raízes foram incluídas em blocos acrílicos e os núcleos cimentados com cimento resinoso. Os espécimes foram armazenados por 24 horas em água deionizada à temperatura ambiente. Os testes de resistência à fratura foram realizados em máquina de ensaios universal, com força de compressão aplicada na porção palatina do núcleo, a uma velocidade de $0,5 \mathrm{~mm} / \mathrm{min}$, em ângulo de $135^{\circ}$ em relação ao longo eixo radicular. Obtiveram-se os seguintes valores de resistência (Kgf) nos grupos: glll- 53,98; gll- 57.64; glV- 76.35; e gl- 87.59. Não houve diferença estatisticamente significativa entre os grupos I e IV, nem entre os grupos II e III. No entanto, os valores encontrados para os grupos II e III 
foram 30\% mais baixos que os dos grupos I e IV (diferença estatisticamente significativa).

BUTZ et al. ${ }^{14}$, em 2001, compararam a taxa de sobrevivência e resistência à fratura de incisivos superiores com defeitos coronais moderados tratados endodonticamente com diferentes sistemas de pinos e núcleos após serem submetidos a uma boca artificial. Sessenta e quatro incisivos centrais superiores humanos livres de cáries foram homogeneamente selecionados, tratados endodonticamente e seccionados a $2 \mathrm{~mm}$ coronalmente a junção cemento-esmalte. $\mathrm{O}$ gl foi restaurado com pinos de titânio e núcleos de resina composta $(\mathrm{RC})$; o gll recebeu pinos de zircônia e núcleos em RC; já o glll foi restaurado com pinos de zircônia com núcleos de cerâmica sinterizada. Um quarto grupo utilizando NMF foi utilizado como grupo controle. Todos os dentes foram preparados e restaurados com coroas totais fundidas. Todas as amostras foram expostas a um 1 milhão e duzentos mil ciclos com termociclagem simultânea numa máquina simuladora da mastigação controlada por computador (Willytech, Alemanha). Após o teste de fadiga as amostras foram carregadas até a fratura numa máquina de ensaios universal. A taxa de sobrevivência dos diferentes grupos foi de $94 \%$ para o gl, 63\% para o gll, 100\% para o glll e 94\% para o gIV. Foram obtidas as seguintes médias de resistência à fratura: gl- $425 \pm 155 \mathrm{~N} ;$ gll- $202 \pm 212 \mathrm{~N} ;$ glll- $378 \pm 64 \mathrm{~N} ;$ glV- $426 \pm 178 \mathrm{~N}$. A carga mais baixa suportada no grupo II foi estatisticamente significativa em relação aos demais grupos. O uso de pinos de zircônia resultou em poucas fraturas 
radiculares oblíquas. Os pinos pré-fabricados de titânio com núcleos em RC, pinos de zircônia com núcleos cerâmicos sinterizados e NMF produziram taxas de sobrevivência e resistência à fratura comparáveis entre si para restauração de incisivos superiores com defeitos coronários moderados e com coroas. A taxa de sobrevivência e resistência à fratura dos pinos de zircônia e núcleos de RC foram significativamente mais baixas e esta combinação não foi recomendada para uso clínico.

HEYDECKE; BUTZ; STRUB ${ }^{33}$, em 2001, compararam a sobrevivência à fadiga termomecânica (1.2 milhões de ciclos) e a resistência à fratura de incisivos superiores com cavidades proximais de $3 \mathrm{~mm}$ de diâmetro restaurados de diferentes formas. O gl foi restaurado com pinos de titânio, o gll recebeu pinos de zircônia e o GIII teve o canal preenchido parcialmente com uma resina composta híbrida. No gIV (controle) somente o acesso coronário foi restaurado com resina composta. Um espécime do GIII não sobreviveu à simulação de mastigação utilizando parâmetros clínicos (impactos de carga a $30 \mathrm{~N}$ ou $3,06 \mathrm{Kgf}$ numa freqüência de $1.3 \mathrm{~Hz}$ ). Os valores de resistência à fratura (N ou Kgf) foram: gl- 1038 ou 105,91, gll1057 ou 107,85, glll- 750 ou 76,53 e gIV- 1171 ou.119,48. O valor médio do glll foi estatisticamente inferior quando comparado aos demais grupos. A reconstrução de dentes uniradiculares tratados endodonticamente com cavidades proximais pode ser realizada com sucesso pelo fechamento do acesso coronário e das cavidades com resina composta. A cimentação de pinos endodônticos oferece resistência à fratura comparável, mas não 
vantajosa quando comparada a não utilização dos mesmos. O alargamento do espaço do canal radicular após a terapia endodôntica deveria ser evitado e não pode ser compensado somente pelo preenchimento de resina composta. Menos falhas catastróficas foram observadas nos espécimes onde os pinos não foram utilizados.

Através do teste de flexão de três pontos, MANNOCCl; SHERIFF; WATSON ${ }^{50}$, em 2001, determinaram a resistência de flexão de cinco tipos de pinos de fibra armazenados sob diferentes condições por um ano. Verificaram que todos os pinos testados apresentaram menores valores de resistência quando armazenados em água a $37^{\circ} \mathrm{C}$ se comparados ao armazenamento a seco ou no interior de dentes bovinos. A partir destes resultados concluíram que os pinos de fibra não devem estar em contato com fluídos orais, já que poderia haver uma degradação da matriz resinosa do pino com conseqüente diminuição da resistência à fratura do mesmo.

RAYGOT; CHAI; JAMESON ${ }^{71}$ em 2001 verificaram se haveria diferença de resistência à fratura e também do tipo de falha entre dentes tratados endodonticamente restaurados com três tipos de pinos, núcleos (NMF, pinos pré-fabricados de aço inoxidável e fibra de carbono com núcleos de resina composta autopolimerizável) e coroa total metálica cimentada com fosfato de zinco. Após a aplicação da carga compressiva na face palatina dos espécimes (angulação de $130^{\circ}$ a uma velocidade de 25,4 $\mathrm{mm} / \mathrm{min}$ ), os valores registrados não se mostraram estatisticamente 
diferentes entre si (38,13 Kgf para os núcleos metálicos fundidos, 31,3Kgf para pinos de fibra de carbono e 31,1 Kgf para os pinos de aço inoxidável) e a maior parte da fraturas se localizaram acima do nível ósseo simulado.Em todos os espécimes houveram falhas adesivas entre o núcleo e a estrutura dentária e na margem da coroa. Concluíram que o uso de pinos de fibra de carbono não alterou a resistência à fratura ou o modo de falha de dentes despolpados quando comparados a pinos metálicos.

Procurando reproduzir um padrão de carga cíclica comparável à função mastigatória fisiológica e desta maneira simular em laboratório a sobrevivência ao longo do tempo obtida por ensaios clínicos prospectivos, STRUB; PONTIUS; KOUTAYAS ${ }^{87}$, em 2001, avaliaram o percentual de sobrevivência e a resistência à fratura de incisivos restaurados com diferentes sistemas de pinos e núcleos. Após a exposição de 1.2 milhões de ciclos de carga numa boca artificial (Willytech, Alemanha), o percentual de sobrevivência foi de $90 \%$ para o grupo A (pino pré-fabricado metálico com núcleo fundido), 80\% para o grupo B (pino de zircônia cimentado com núcleo cerâmico pré-fabricado), 60\% para o grupo C (pino resinoso-cerâmico cimentado com núcleo cerâmico pré-fabricado) e 100\% para o grupo D (pino de zircônia fundido a núcleo personalizado). As médias de valores máximos de resistência à fratura ( $\mathrm{N}$ ou Kgf) durante a carga estática com os respectivos desvios padrão foram: gA- 1270 ( \pm 312.5) ou 129,59, gB-1495 $( \pm 333.5)$ ou $152,55, g C-1146( \pm 182.6)$ ou 116,93 e gD- $463.3( \pm 46.2)$ ou 47,27. Apesar de nenhum espécime do grupo D fraturar durante a aplicação 
das cargas dinâmicas, foi neste grupo que se encontrou a menor média de resistência á fratura quando comparada às médias dos demais grupos. Apesar disso, considerou-se um valor de resistência clinicamente aceitável.

AKKAYAN; GÜLMEZ² em 2002 compararam a resistência à fratura e modo de falha de caninos superiores restaurados com pinos de titânio (I) e pinos estéticos (pinos de fibra de quartzo [II], fibra de vidro [III] e cerâmico [IV]). Todos os pinos foram cimentados com o mesmo adesivo (Single Bond) e o mesmo cimento de cura dual (Rely X ARC). Foram confeccionados núcleos em resina composta e coroas totais metálicas foram cimentadas com cimento de ionômero de vidro. Os corpos de prova foram então submetidos à carga compressiva numa inclinação de $130^{\circ}$, a uma velocidade de $1 \mathrm{~mm} / \mathrm{min}$ até que a falha radicular ocorresse. As médias de carga $(\mathrm{Kg})$ para a falha foram $66.95,91.20,75.90$ e 78.91 para os grupos de I-IV respectivamente. Os dentes restaurados com fibra de quartzo exibiram a mais alta resistência entre os três grupos estatisticamente diferente $(P<0.01)$. Já aqueles restaurados com fibra de vidro e cerâmica foram estatisticamente semelhantes entre si (P> 0.05). Em relação ao modo de falha, as fraturas que permitiram reparo dos dentes foram observadas nos grupos II e III, enquanto fraturas irreparáveis foram observadas nos grupos I e IV.

Diante do crescimento na utilização de pinos resinosos reforçados por fibras, FINGER; AHLSTRAND; FRITZ ${ }^{23}$, em 2002, propuseram-se a avaliar 
comparativamente a radiopacidade de oito tipos de pinos (1 de titânio: Komet Vlock e 7 pinos resinosos: Aestheti-Plus; FibreKor; Light post [1.8, 1,2]; Mirafit White; Snowlight; Snowpost). Através de análises densitométricas das radiografias dos pinos, isolados e assentados em caninos humanos, cimentados com cimentos resinosos ou não, os mesmos foram ordenados decrescentemente segundo radiopacidade e visualização na radiografia. As radiopacidades dos pinos resinosos testados foram consideravelmente mais baixas do que a do pino de titânio. Do ponto de vista clínico, somente os pinos resinosos de nome comercial Fibrekor, Snowlight e Snowpost foram considerados radiopacos o suficiente para visualização inequívoca nas radiografias dentárias.

Procurando saber qual o método de corte ideal dos pinos de fibra, GRANDINI; BALLERI; FERRARI ${ }^{30}$ em 2002, investigaram por MEV, a integridade de seis tipos de pinos após o corte. Cada grupo foi subdividido em três subgrupos de acordo com a forma de corte: ponta diamantada, disco de carborundum e tesoura. Todos os grupos mostraram diferenças entre as superfícies cortadas com tesouras e aquelas cortadas ou com ponta diamantada ou com disco de carborundum. Com as pontas diamantadas os pinos apresentaram superfícies regulares após o corte. A maioria dos pinos cortados com disco de carborundum apresentou superfície regular. Já as superfícies cortadas por tesoura mostraram-se com dois planos e bordas convergentes, além da formação de linhas de fratura nestes pinos que comprometeram sua integridade. Estes resultados indicam que a forma mais 
adequada de se cortar pinos de fibra é através de ponta diamantada sob abundante refrigeração.

HEYDECKE et al. ${ }^{35}$, em 2002, quiseram saber qual a resistência à fratura de dentes tratados endodonticamente restaurados com quatro tipos de pinos e núcleos após aplicação de ciclagem dinâmica. Sessenta e quatro incisivos centrais superiores foram divididos em quatro grupos de acordo com o material a ser restaurado. Grupo I: pinos de titânio com núcleos em resina composta (RC); grupo II: pinos de zircônia e núcleos em RC; grupo III: pinos de zircônia fundidos em núcleos cerâmicos e grupo IV (controle): núcleos metálicos fundidos em ouro. Os dentes foram preparados com um término em ombro incluindo férula de 1 a $2 \mathrm{~mm}$. Todos os dentes foram expostos a 1.2 milhões de ciclos de carga (30N) num simulador de mastigação controlado por computador. Termociclagem simultânea entre $5^{\circ} \mathrm{C}$ e $55^{\circ} \mathrm{C}$ foi aplicada por 60 segundos (s) com pausa intermediária de 12 s. Os espécimes que não fraturaram durante os ciclos de impacto foram carregados até a fratura numa máquina de ensaios universal de testes a uma velocidade de $1.5 \mathrm{~mm} / \mathrm{min}$. As cargas foram aplicadas numa angulação de $130^{\circ}$ na borda incisal. Os valores de carga para a fratura $(\mathrm{N}=9,80 \mathrm{Kgf})$ e os modos (reparáveis ou catastróficas) foram registrados. Após a simulação da mastigação as taxas de sobrevivência foram: gl- 93.8\%, gll- 93.8\%, glll100\% gIV- 87.5\%. As médias de resistência à fratura dos grupos I ao IV foram, respectivamente, 450N (45,91Kgf), 503N (51,32Kgf), 521N (53,16Kgf) e $408 \mathrm{~N}(41,63 \mathrm{Kgf})$. Nenhum dos valores entre os grupos se mostrou 
significativamente diferente. O uso de pinos de zircônia resultou num número insignificante de fraturas radiculares catastróficas. Ensaios clínicos são necessários para verificação destes resultados laboratoriais.

PILO et al. ${ }^{65}$, em 2002, avaliaram o efeito da dureza do núcleo sobre a resistência à fratura de dentes tratados endodonticamente com coroas. Quarenta pré-molares inferiores foram divididos em quatro grupos iguais. glNMF; gll- pino pré-fabricado metálico com núcleo de resina composta; glll-: pino pré-fabricado com núcleo em amálgama e gIV- pino pré-fabricado sem núcleo. Após o teste de aplicação de carga a $30^{\circ}$ numa velocidade de $2 \mathrm{~mm} / \mathrm{min}$ não se observou diferença estatisticamente significativa entre os grupos. Na presença de coroas, a rigidez do núcleo não afetou a resistência à fratura de dentes restaurados com diferentes pinos e núcleos. Somente o padrão de falha foi modificado. Apenas os núcleos em resina composta exibiram fraturas reparáveis, apesar de fraturas irreparáveis também terem sido verificadas para este tipo de núcleo.

PONTIUS; HUTTER ${ }^{67}$, em 2002, avaliaram a taxa de sobrevivência e resistência à fratura de incisivos centrais superiores tratados endodonticamente restaurados com diferentes sistemas de pinos e núcleos e sem nenhum reforço corono-radicular submetidas ao teste de fadiga. No grupo A utilizou-se NMF com liga nobre. No grupo B utilizou-se pino de zircônia. No grupo C (experimental) pino resinoso reforçado por cerâmica e núcleo cerâmico pré-fabricado. No grupo D não se utilizou nenhum pino ou 
núcleo, apenas uma resina composta fechando o acesso radicular. Após ciclagem mecânica (1.2 milhões de ciclos) e termociclagem, as taxas de sobrevivência foram: gA- (90\%), gB-(80\%), gC- (60\%) e gD-(100\%). As amostras restauradas com NMF apresentaram mais fraturas radiculares verticais. Concluíram que a preservação de ambas estruturas interna e externa são essenciais na restauração de dentes tratados endodonticamente.

AL-HARBI; NATHANSON ${ }^{5}$, em 2003, estudaram a resistência à tração de sistemas de pinos endodônticos resinosos (Fibrekor; Luscent; Twin Luscent Anchors), cerâmicos (Cerapost; Cosmopost) e um de titânio (Ti) como controle. Na primeira parte da pesquisa testou-se a capacidade retentiva destes pinos a um núcleo resinoso (Bis-Core). Num segundo momento, avaliou-se a retenção dos mesmos em remanescentes dentários (84 caninos humanos), quando a cimentação resinosa foi realizada nos seis grupos, além de cimentação com fosfato de zinco em um grupo controle adicional com o pino de Ti. A textura de superfície de cada pino foi previamente analisada através de microscopia eletrônica de varredura (MEV) com aumento de 25 X e 250 X. A retenção do pino de Ti ao núcleo foi mais alta que todos os pinos estéticos testados. Em relação à retenção dentária, os pinos resinosos tiveram maior resistência que os cerâmicos.

DRUMMOND; BAPNA ${ }^{19}$, em 2003, avaliaram a resistência flexural de pinos resinosos reforçados por fibras unidirecionais sob carga estática e 
cíclica, com e sem termociclagem. Os pinos resinosos de fibra de carbono e vidro (Fiberkor) foram significativamente mais resistentes que o pino de cerâmica e os outros reforçados por fibra de vidro. A termociclagem provocou uma significativa diminuição (11-24\%) na resistência flexural de cada sistema de pino resinoso. Já o pino cerâmico apresentou uma diminuição de apenas 2\%. A diminuição encontrada nas propriedades de resistência destes materiais, como conseqüência não só da termociclagem, mas também dos ciclos de carga, indicou que a utilização de pinos resinosos no meio oral aumenta sua degradação e potencialmente diminui sua vida clínica.

HU et al. ${ }^{36}$, em 2003, quiseram avaliar a resistência à fratura oferecida por quatro sistemas de pinos e núcleos quando utilizados como materiais restauradores de dentes tratados endodonticamente. Quarenta incisivos centrais superiores foram aleatoriamente divididos em quatro grupos iguais: gl- NMF a partir de pino paralelo e serrilhado; gll- pino de aço inox paralelo e serrilhado com núcleo em resina composta (RC); glll- pino de fibra de carbono com núcleo em resina composta; gIV- pino cerâmico com núcleo em RC. Todos os espécimes foram submetidos a uma carga compressiva com angulação de $45^{\circ}$ (em relação ao seu longo eixo) até a falha. A carga e o modo de fratura foram registrados. Não houve diferença estatisticamente significativa nos valores de carga para a falha entre os grupos, porém mais fraturas radiculares do tipo catastróficas foram observadas nos grupos restaurados com pinos cerâmicos e núcleos em resina composta. 
KAIZER ${ }^{39}$ em 2003 avaliou a resistência à fratura de dentes tratados endodonticamente restauradas com pinos de fibra de polietileno e pinos dentários. Sessenta raízes de caninos foram distribuídas em quatro grupos: grupo I e II preparo convencional restaurado com pinos de fibra de polietileno e pino dentário, respectivamente, e grupos III e IV preparos simulando alargamento radicular médio e amplo. Ambos os grupos foram restaurados com pinos dentários. Todos os pinos foram cimentados com sistema adesivo químico (Scotchbond Multi-Uso) e cimento dual (Enforce). As porções coronárias foram reconstruídas com resina composta autopolimerizável reforçada por titânio (Ti-Core). Após os espécimes serem submetidos ao teste de compressão só se encontrou diferença estatística entre os grupos III (maior valor) e o grupo I (menor valor). Os demais grupos restaurados com pinos dentários demonstraram valores de resistência semelhantes. As conseqüências do enfraquecimento radicular puderam ser melhoradas com o pino dentário.

$\mathrm{KREJCl}$ et al. $^{41}$, em 2003, obtiveram dados sobre a qualidade de adaptação marginal, resistência à fratura e retenção de 4 tipos de preparos de restaurações adesivas de resina composta sobre pré-molares com canal radicular tratado (gll- coroa total sem pino; gllI- coroa total com pino; gIVinlay; gV- onlay) antes e depois de um teste de fadiga. Estes foram comparados com resultados de um grupo controle restaurado (onlays adesivas de resina composta) sobre dentes "vitais" (soro de cavalo diluído 
para simular o fluído pulpar). A adaptação marginal foi analisada antes e depois da aplicação dos impactos oclusais (1, 200,000 ciclos de carga máxima de $49 \mathrm{~N}$ ou $5 \mathrm{Kg}$ ) pelo uso da técnica da réplica e quantitativamente por uma avaliação por MEV com aumento de 200X. O número de restaurações perdidas foi registrado após os ciclos. A resistência à fratura e o padrão de fratura das amostras foram obtidos após o teste de fadiga. Nenhuma diferença significativa $(p>0.05$ ) entre os grupos foi detectada antes ou depois dos impactos em relação à porcentagem de margem continua no comprimento total da margem. Os impactos de carga exerceram influência significativa $(p<0.05)$ sobre a continuidade da margem somente nos grupos II e IV. Também não foi detectada diferença significativa ( $p$ > 0.05) entre os valores de resistência à fratura e nenhuma restauração perdida foi observada. Os resultados sugerem que a técnica restauradora adesiva minimamente invasiva para dentes desvitalizados, com pouca ou significativa destruição, é promissora.

MACCARI; CONCEIÇÃO; NUNES ${ }^{47}$, em 2003, compararam a resistência à fratura de pinos pré-fabricados estéticos. Neste estudo trinta dentes, entre incisivos centrais e caninos superiores, foram tratados endodonticamente e restaurados com pinos de fibra de vidro, pinos de fibra de carbono revestidos por quartzo e pinos de cerâmica e núcleos em resina composta nos três grupos. O teste de resistência à fratura foi realizado numa angulação de $45^{\circ}$ em relação ao longo eixo do dente, a uma velocidade de $0.5 \mathrm{~mm} / \mathrm{min}$, porém sem a presença de coroa. A resistência dos pinos 
cerâmicos foi significativamente mais baixa do que a dos pinos de fibra, além de apresentar fratura dos pinos e fraturas radiculares em três espécimes. Já nos espécimes com pinos de fibra as fraturas ocorreram sobre o núcleo de resina composta.

MARCHI et al. ${ }^{52}$, em 2003, avaliaram a resistência à fratura de raízes bovinas internamente enfraquecidas, reconstruídas com diferentes materiais de preenchimento associados a um pino metálico pré-fabricado. Os resultados foram comparados com raízes restauradas que estavam relativamente intactas (controle). Foram testados os seguintes materiais de preenchimento: gl-cimento resinoso (All bond C\&B), gll-cimento de ionômero de vidro resinoso (Vitremer), glll-resina composta modificada por poliácido (Dyract AP) e gIV-resina composta (Z-100). As médias de resistência à fratura (em Kgf) em ordem decrescente foram: controle 52.38, gll- 42.68, glll- 39.33, gIV- 39.29 e gl- 31.75. Verificou-se diferença estatisticamente significativa em relação à condição radicular. As raízes enfraquecidas foram menos resistentes fratura do que as do grupo controle (íntegras). As restauradas com cimento resinoso demonstraram os mais baixos valores de resistência, porém estes dados só foram significativos quando comparados aos valores das raízes restauradas com cimento de ionômero de vidro modificado por resina. As raízes restauradas com cimento de ionômero de vidro modificado, as restauradas com resina composta modificada por poliácido e aquelas restauradas com resina composta comportaram-se similarmente. Nenhum dos materiais avaliados foi capaz de alcançar os 
valores de resistência registrados para as raízes não enfraquecidas (controle).

NEWMAN et al. ${ }^{62}$, avaliaram em 2003 a resistência à fratura de dentes tratados endodonticamente restaurados com pinos resinosos. Noventa incisivos centrais superiores foram divididos em 8 grupos experimentais (pinos resinosos) e um grupo controle (pino metálico de aço inox). Oitenta dentes foram divididos em dois grupos experimentais principais. Um classificado como canal estreito e outro alargado. Para os grupos com canais estreitos o espaço para o pino foi realizado com as brocas correspondentes aos pinos de fibra de vidro (Fibrekor e Luscent Anchors) e pinos de fibra trançada de polietileno (Ribbond) com diâmetros de $1.5,1.6$ e $2.0 \mathrm{~mm}$ respectivamente. Para os grupos com canais afunilados, canais com paredes dentinárias delgadas $(2-2,2 \mathrm{~mm}$ de espessura) foram simuladas com broca cônica. Estes dentes enfraquecidos foram restaurados com os mesmos pinos, porém cimentados em canais com $2 \mathrm{~mm}$ de largura no terço coronal. Além destes, 20 pinos de fibra de polietileno com porções coronárias de tamanho e forma variados também foram preparados e avaliados. Os espécimes foram carregados (Kgf) até que a falha ocorresse para que os dados fossem registrados. As análises estatísticas revelaram que não houve diferença significativa entre os canais estreitos e afunilados nas médias de carga para a falha entre os sistemas de pino exceto para os de fibra de polietileno. Para o canal estreito a média de carga alcançada mais baixa foi 4.55 ( \pm 1.49) Kgf para o Ribbond com porção 
coronária padronizada e a mais alta 12.9 ( \pm 1.64) Kgf para o Luscent Anchors. Para o canal afunilado a média de carga mais baixa foi 9.04 ( \pm 1.76) Kgf para o Fibrekor e as mais altas foram equivalente para o Luscent Anchors (12.87 \pm 2.69$)$ e para Ribbond padronizado $(12.87 \pm 3.54 \mathrm{Kgf})$. Em geral, o grupo controle (Parapost) obteve os mais altos valores de carga com média de 18.33 ( \pm 3.27) Kgf. Os pinos Ribbond não padronizados tiveram uma média de carga para falha de 24.91( \pm 11.53) Kgf para o grupo com canal estreito e 31.95 ( \pm 11.98) para o canal afunilado. Porém, estes valores não foram incluídos na análise estatística pelo tamanho não uniforme dos núcleos e pelo alto desvio padrão. Nenhuma fratura foi observada nos grupos experimentais. Reconheceu-se como limitação desta pesquisa, a realização dos testes de compressão diretamente sobre os pinos que descaracterizou a simulação clínica e dificultou maiores conclusões ou comparações entre resultados.

PURTON; CHANDLER; QUALTROUGH ${ }^{68}$, em 2003, investigaram os efeitos da termociclagem sobre a retenção de pinos de fibra de vidro. Quarenta raízes de pré-molares e caninos foram incluídas em blocos acrílicos para se adaptarem ao aparelho de retenção. As raízes foram aleatoriamente divididas em dois grupos que receberam pinos Lightpost ou Luscent Anchors cimentados com cimento resinoso (Panavia F) numa profundidade $9 \mathrm{~mm}$. Em cada grupo metade dos espécimes foi submetida a 3 mil ciclos de banhos com $5^{\circ}$ e $55^{\circ}$ de temperatura com 60 segundos de intervalo. A outra metade serviu de controle. Não existiu diferença 
estatisticamente significativa nas forças necessárias para causar à falha de retenção entre os espécimes termociclados e os controle. Os pinos de fibra de vidro cimentados com cimento resinoso ofereceram níveis aceitáveis de retenção e não foram susceptíveis as diminuições de retenção provocada pela termociclagem.

REID; KAZEMI; MEIERS ${ }^{74}$, em 2003, avaliaram concomitantemente a estabilidade do pino/núcleo e a microinfiltração do complexo pino/núcleo/cimento frente a um teste de estresse a fadiga de baixo impacto. Cinqüenta dentes uniradiculares foram restaurados com um dos seguintes sistemas de pinos e núcleos em resina composta: pino pré-fabricado de titânio (ParaPost) cimentado com fosfato de zinco ou pino de fibra de carbono (C-post), pino de fibra de carbono envolvida por quartzo (Esthetic Cpost), pino de fibra de vidro (FibreKor) e pino cerâmico (CosmoPost), ambos cimentados com cimento resinoso. Os corpos de prova foram posicionados numa angulação de $45^{\circ}$ em relação ao longo eixo dental e carregados com uma força de $55 \mathrm{~N}(5,39 \mathrm{Kgf})$ numa freqüência de $3 \mathrm{~Hz}$ por 100.000 impactos. Após 60.000 impactos as amostras foram termocicladas. A integridade do núcleo e microinfiltração do pino foram avaliadas durante todos os cem mil impactos. As amostras não mostraram deslocamento detectável de qualquer um dos núcleos, mas o grupo metálico apresentou um aumento estatisticamente significativo na microinfiltração quando comparado aos grupos de pinos não metálicos. 
ZHI-YUE; YU-XING ${ }^{98}$, em 2003, avaliaram o efeito do tipo de pino/núcleo e da férula sobre a resistência à fratura de 48 incisivos centrais superiores distribuídos em 4 grupos. No grupo A os dentes receberam somente um preparo para coroa metalocerâmica. No grupo B os dentes foram preparados para possuírem uma altura de férula de $2 \mathrm{~mm}$ e restaurados com NMF (NMF). O grupo C, sem nenhum remanescente, recebeu NMF. O grupo D com um remanescente de $2 \mathrm{~mm}$, foi restaurado com pinos de aço pré-fabricados e núcleos de preenchimento em resina composta. Após serem submetidos à carga $(\mathrm{N})$ sob a superfície palatina encontrou-se diferença estatisticamente significativa entre os resultados dos quatro grupos estudados. O grupo B obteve a mais alta resistência à fratura (1793.59 $\pm 387.93 \mathrm{~N}$ ou $183,01 \mathrm{Kgf})$. Já para os demais grupos não houve diferença significativa (gA- $958.49 \pm 286.02$ ou $97,80 \mathrm{Kgf} ;$ gC- $992.98 \pm$ 291.00 ou 101,32Kgf; gD- $994.94 \pm 285.04 \mathrm{~N}$ ou 101,52Kgf). Nesta investigação laboratorial os dentes preparados com uma férula dentinária de $2 \mathrm{~mm}$ de altura tiveram sua resistência aumentada.

AKKAYAN $^{3}$ em 2004, avaliou o efeito de três diferentes comprimentos de férula sobre a resistência à fratura de dentes tratados endodonticamente restaurados com quatro tipos de pinos (fibra de quartzo, fibra de vidro, fibra de vidro acrescida de zircônia e zircônia), núcleos em resina composta e coroas totais metálicas. Três variações de férula $(1.0 \mathrm{~mm}, 1.5 \mathrm{~mm}$ e $2.0 \mathrm{~mm})$ foram preparadas em 123 coroas de caninos superiores. Estes espécimes foram carregados tangencialmente numa angulação de $130^{\circ}$ em relação ao 
seu longo eixo a uma velocidade de $1 \mathrm{~mm} / \mathrm{min}$ até a sua fratura. Os modos de fratura foram classificados como falhas acima ou abaixo do terço incisal das raízes. As médias de carga (Kgf) para a falha dos grupos de fibra de quartzo, fibra de vidro, fibra de vidro mais zircônia e zircônia foram respectivamente: na presença de férula com 1mm, $98.09( \pm 2.90), 85.36( \pm$ 2.82), 80.24 ( \pm 1.88), 70.11 ( \pm 2.48$)$; com férula de 1.5mm, $101.0( \pm 2.88)$, 87.58 ( \pm 2.83$), 89.8$ ( \pm 2.09$), 82.71( \pm 2.14)$ e com férula de $2.0 \mathrm{~mm}, 119.5( \pm$ 1.78), $99.84( \pm 1.23), 98.6( \pm 1.64), 95.42$ ( \pm 1.02$)$. Os dentes preparados com férula de $2 \mathrm{~mm}$ demonstraram limiares de fratura significativamente mais altos. O modo de falha não diferiu entre os grupos.

AKSORNMUANG et al. $^{4}$, em 2004, avaliaram a resistência por microtensão adesiva entre pinos de fibra de vidro e quartzo com uma resina composta para núcleo de polimerização dupla. Diversas formas de tratamento de superfície dos pinos foram testadas: (gl- sem tratamento de superfície; gll- sistema adesivo dual de dois frascos aplicado e seco com leve jato de ar; gllI- mesmo tratamento anterior seguido de fotopolimerização por 20 s.; gIV- agente silano de cobertura mais sistema adesivo fotopolimerizável e seco com leve jato de ar; gV- mesmo tratamento anterior com fotopolimerização por 20s. Entre as formas de tratamento de superfície, aquela que proporcionou maior resistência à microtensão adesiva dos pinos à base de sílica foi às que utilizaram agente silano de cobertura antes do adesivo. Para os pinos de fibra de vidro contendo sílica e zircônia 
(Snowpost) a resistência foi aumentada quando 0 adesivo foi fotopolimerizado.

BOLHUIS; DE GEE; FEILZER ${ }^{12}$ avaliaram em 2004 a influência da fadiga por carga na qualidade da camada de cimento entre pinos e paredes de canais radiculares de pré-molares. Os pinos selecionados para este estudo foram três pinos pré-fabricados (pino de titânio, pino de fibra de quartzo e pino de fibra de carbono coberto com quartzo) com núcleos em resina composta e um NMF. Para cada grupo $(n=8)$ metade dos espécimes foram submetidos a $10^{6}$ ciclos mecânicos numa angulação de $85^{\circ}$, enquanto a outra metade foi utilizada como controle. Três secções radiculares transversais e paralelas com $1.5 \mathrm{~mm}$ de espessura foram cortados de cada espécime. Estas secções foram examinadas através de MEV para visualização da integridade do cimento. A retenção dos pinos foi avaliada pelo teste push-out. Verificaram que a fadiga não provocou a separação das reconstruções das raízes e também não afetou a resistência à tração. Somente na análise por MEV verificou-se diferença estatística significativa entre o tipo de pino, ciclagem mecânica e níveis de seccionamento radicular. A integridade do cimento com o pino de titânio foi significativamente menor do que os outros três sistemas que não diferiram entre eles. Concluiu-se que restaurações com núcleo de resina composta unida à dentina e suportada por pinos de fibra de quartzo ou fibra de carbono coberta com quartzo, cimentados com cimento resinoso, podem ser uma alternativa aos núcleos metálicos fundidos convencionais. 
LASSILA et al. ${ }^{42}$, em 2004 testaram propriedades flexurais de pinos intra-radiculares reforçados por fibra. Dezessete diferentes pinos resinosos reforçados por fibra (de sílica-zircônia, de carbono e de vidro) de várias marcas (Snowpost, Carbopost, Parapost, C-post, Glassix, Carbonite) e diâmetros $(1.0-2.1 \mathrm{~mm})$ foram comparados com um novo material resinoso reforçado por fibra de vidro (everStick, 1.5mm de diâmetro). Os pinos $(n=5)$ foram armazenados em sala úmida ou termociclados $\left(12.000 \mathrm{X}, 5 \% 55^{\circ} \mathrm{C}\right)$ e submersos em água por 2 semanas antes do teste. $O$ teste de três pontos foi utilizado para medir a resistência e o módulo flexural dos pinos. A análise estatística revelou que a termociclagem, marca do material e diâmetro do espécime tiveram influência significativa $(p<0,001)$ sobre a resistência flexural e a carga para fratura. A resistência flexural mais alta foi obtida com o material everStick $1144.9 \pm 99.9 \mathrm{MPa}$. Existiu uma relação linear entre o valor de carga para a fratura e o diâmetro dos pinos tanto para o de fibra de vidro como para o de fibra de carbono. A termociclagem diminuiu as três propriedades mecânicas avaliadas. O módulo de elasticidade teve uma diminuição de aproximadamente $10 \%$ em relação aos pinos não termociclados. O valor de carga para a fratura e a resistência flexural tiveram valores reduzidos cerca de $18 \%$. Variações consideráveis foram encontradas nos valores de resistência das marcas dos pinos estudados.

MITSUI et al. ${ }^{57}$, em 2004, avaliaram a resistência à fratura de raízes bovinas restauradas com cinco diferentes tipos de pinos intra-radiculares. 
Setenta e cinco raízes de dimensões similares foram divididas de acordo com o sistema utilizado: NMF; pinos pré-fabricados de titânio, de fibra de vidro, fibra de carbono e cerâmicos reconstruídos com núcleo de resina composta. Os espécimes foram carregados continuamente numa velocidade de $0,5 \mathrm{~mm} / \mathrm{min}$ com uma angulação de $135^{\circ}$ em relação ao longo eixo do espécime até a sua fratura. Observou-se o maior valor médio para os pinos de titânio, similar ao pino de fibra de carbono, quando comparados aos pinos de fibra de vidro e zircônia que apresentaram os menores valores. Todos os pinos avaliados apresentaram resistência à fratura similar quando comparados ao NMF e entre os pré-fabricados, pinos de titânio e carbono foram os mais indicados.

MONTICELLI; GORACCI; FERRARI ${ }^{59}$ compararam, em 2004, a utilização de três resinas compostas híbridas (Z-100, Lumiglass e Gardia) com uma resina dual reforçada por fibra (Build-it) na reconstrução de núcleos sobre pinos de fibra. Estes materiais foram utilizados com ou sem uma matriz coronária para reconstrução dos núcleos. Os espécimes foram seccionados perpendicularmente e observados em vários aumentos por MEV na busca de espaços ou bolhas dentro do núcleo de resina e falhas (gaps) na interface entre a superfície do pino e da resina. Verificaram que as resinas compostas híbridas proporcionaram uma maior homogeneidade do núcleo e uma integração melhor do pino a própria resina sem a utilização de qualquer matriz para reconstrução do núcleo. 
ROBERTS et al. ${ }^{75}$, avaliaram em 2004 o efeito da transmissão de luz a partir de um pino de fibra de vidro (Luscent-Anchors), sobre a profundidade de cura de uma resina composta fotopolimerizável. Isto foi realizado através de moldes de acetato com $15 \mathrm{~mm}$ de altura, preenchidos com a resina composta. A fotopolimerização foi feita com e sem o pino de fibra de vidro. Os espécimes foram seccionados em 5 diferentes níveis de altura (0-2mm; 3-6mm com $1 \mathrm{~mm}$ de espessura entre cada seccionamento). A profundidade de cura foi determinada utilizando a dureza Knoop de cada parte do espécime seccionado. A presença do pino não aumentou a dureza Knoop nas regiões apicais simuladas quando comparados ao controle (sem pino). Por este estudo a idéia de condução da luz através do pino de fibra de vidro testado até regiões apicais não foi confirmada.

SAHAFI et al. $^{76}$, quiseram saber em 2004, qual a influência do cimento, do material, da forma e da superfície de tratamento do pino sobre a retenção e falha morfológica de pinos pré-fabricados. Pinos de titânio, fibra de vidro e zircônia foram cimentados com três tipos de cimentos: fosfato de zinco, cimento resinoso convencional à base de Bis-GMA (Parapost Cement) e cimento resinoso a base de MDP (Panavia F). Previamente à cimentação os pinos não receberam nenhuma tratamento de superfície ou foram submetidos a um dos seguintes tratamentos: jateamento com partículas de alumina $(50 \mu \mathrm{m})$, jateamento com partículas de alumina cobertas com silicato(30 $\mu \mathrm{m})$, aplicação de primers de cobertura (Metalprimer) ou jateamento mais aplicação de silano. A retenção foi determinada pela 
remoção dos pinos de caninos e incisivos. A falha morfológica foi analisada e quantificada visualmente por estereomicroscópio com aumento de 18X, sendo caracterizada pela quantidade de cimento aderido ao pino e quantificada pelo percentual de área do pino coberta pelo cimento. Observaram que como conseqüência da adesão limitada do cimento no canal radicular, a superfície de tratamento nem sempre exerceu um efeito positivo sobre a retenção. Concluíram que a escolha do cimento foi crítica para os três tipos de pinos e a forma paralela ofereceu retenção superior à cônica.

SANTOS; EL-MOWAFY; RUBO ${ }^{77}$, em 2004, avaliaram a resistência à tensão diametral de um núcleo em resina composta quando associado a pinos pré-fabricados não metálicos. Espécimes cilíndricos foram preparados a partir da resina composta e um dos seguintes pinos: resinosos reforçados com fibra de vidro (Vectris, Fibrekor e Dentorama) e fibra de quartzo (Aestheti-Plus e Light-Post). Espécimes sem pinos (só resina) e com pinos metálicos também foram avaliados. Corpos de prova representativos de cada grupo foram analisados por MEV para determinação da natureza da falha após o teste na máquina de ensaios universal. Verificaram que o uso de pinos não reforçou o núcleo de resina composta quando a força de tensão diametral foi aplicada. Os pinos que resultaram nos mais altos valores de resistência a tensão diametral foram o Light-Post, Dentorama e Fibrekor, enquanto que o pino de aço resultou no menor valor. Em relação 
aos padrões de falha, ocorreram falhas adesivas para os pinos metálicos e falhas coesivas para a maioria dos pinos não metálicos.

USUMEZ et al. ${ }^{94}$, em 2004 avaliaram a efetividade de selamento promovida por diferentes pinos endodônticos. Após análise estatística os pinos de fibra de vidro e os pinos de fibra de polietileno mostraram as mais baixas infiltrações coronárias quando comparados aos pinos de aço e pinos de zircônia em todos os períodos avaliados (1 semana, 3 e 6 meses). Os pinos de fibra de polietileno e fibra de vidro testados podem ser alternativas promissoras aos pinos metálicos no que se refere a capacidade de selamento.

XIBLE $^{96}$, em 2004, avaliou o efeito da aplicação de carga cíclica na resistência à fratura de dentes reconstruídos com pinos metálicos convencionais e estéticos restaurados com coroas de porcelana pura. Sessenta caninos foram distribuídos em seis grupos. Os grupos I e II foram restaurados com pinos pré-fabricados de zircônia (Cosmopost) e núcleo de preenchimento em cerâmica vítrea termo-injetada (IPS-Empress). Os grupos III e IV foram restaurados com pinos de fibra de vidro (Fibrekor) e os grupos V e VI com pinos de Titânio (Azthec Anchor). Nos grupos III, IV, V e VI foi usada à resina composta reforçada por fibra de vidro (Build-it Fiber Reinforced Core) para o núcleo de preenchimento. Tanto os pinos quanto as coroas foram cimentados com cimento resinoso dual (Cement It/ Bond It). Os espécimes foram submetidos à ciclagem térmica por 300 X, em temperatura 
de $5^{\circ} \mathrm{C}$ e $55^{\circ} \mathrm{C}$ e incluídos em blocos de resina acrílica e de alumínio. Os grupos II, IV e VI foram submetidos 500.000 ciclos de carga (250N ou 25,5Kgf) numa freqüência de $1.7 \mathrm{~Hz}$. Os 6 grupos foram submetidos à carga estática até a falha dos sistema onde o valor de resistência máxima e o modo de fratura foram registrados. Os dentes restaurados com pinos de zircônia e núcleos de porcelana apresentaram os maiores valores de resistência à fratura. O tratamento com carga cíclica reduziu significativamente a resistência em todos os grupos testados. Não houve diferença de resistência à fratura entre os dentes restaurados com pinos de fibra de vidro e titânio e também correlação entre o tipo de pino e o modo de fratura.

CARVALHO et al. ${ }^{16}$, em 2005 avaliaram a eficácia de reforços radiculares através da fotopolimerização de resina composta ou pino de zircônia em dentes desvitalizados. Foram utilizados 56 incisivos bovinos que tiveram suas coroas removidas para se obter um comprimento padrão de 30mm. Os espécimes foram divididos em 4 grupos $(n=14)$ : gl- canais instrumentados, alargados (para simular rizogênese incompleta) e reforçados com resina composta fotopolimerizada através de pinos fototransmissores (LUMINEX); gll- canais instrumentados, alargados e reforçados com pinos de zircônia; glll- tratamento similar aos gl e gll, sem reforço radicular; gIV- raízes sem enfraquecimento e sem reforço radicular. Os dentes foram submetidos a forças compressivas numa angulação de $45^{\circ}$ numa velocidade de $1 \mathrm{~mm} / \mathrm{min}$ até à fratura. Os resultados mostraram 
maiores valores de resistência à fratura no gl e gll (122.38 e 122.08 Kgf, respectivamente) sem diferença estatisticamente significativa entre si ( $p>$ 0.05), porém significativamente diferente entre os gIII (78.28) e gIV (133.06) $(p<0.05)$. A utilização de reforços radiculares como pino de zircônia ou resina composta fotopolimerizável aumentou significativamente a resistência estrutural de dentes fragilizados, porém não o suficiente para alcançar valores de dentes sem enfraquecimento. Concluíram que, uma vez fragilizadas, as raízes devem ser restauradas para que sua resistência aumente, mesmo que este reforço não tenha oferecido valores equivalentes aos obtidos pelas raízes sem perda de estrutura dentinária.

YOLDAS; ALACAM ${ }^{97}$, em 2005, por meio de testes de microdureza da resina composta fotopolimerizável, compararam a profundidade de cura destas obtida por pinos plásticos fototransmissores (LUMINEX) e pinos resinosos reforçados por fibra de vidro (Postec). Trinta cilindros de plástico preto, medindo $15 \mathrm{~mm}$ de comprimento e $4 \mathrm{~mm}$ de diâmetro, foram utilizados simulando o canal radicular. Estes foram preenchidos com resina e fotopolimerizados por 90s através dos dois grupos experimentais, além do controle sem pino. A microdureza da resina foi avaliada em superfícies distantes da fonte de exposição da luz nos seguintes comprimentos: $2 \mathrm{~mm}$, $4 \mathrm{~mm}, 6 \mathrm{~mm}, 8 \mathrm{~mm}, 10 \mathrm{~mm}, 12 \mathrm{~mm}$ e $14 \mathrm{~mm}$. Os resultados mostraram um significativo aumento da microdureza da resina composta (profundidade de cura) obtido tanto com o pino plástico como com o pino de fibra de vidro quando comparados ao grupo controle. Entre estes, o pino de plástico 
permitiu valores de microdureza significativamente superiores após $8 \mathrm{~mm}$ indicando maior eficiência na transmissão da luz, em níveis mais profundos, do que o pino de fibra de vidro avaliado. Em todos os grupos a microdureza da resina composta diminuiu com o aumento da distância da ponta da fonte de luz.

\section{3 - Estudos clínicos}

SILVERSTEIN ${ }^{81}$, em 1964, atribuiu aos núcleos e pinos intraradiculares a finalidade de proporcionar suporte a uma restauração, uma vez que dentes tratados endodonticamente apresentavam-se enfraquecidos e mais predispostos a fraturas pela perda de estrutura decorrente da cárie e de procedimentos endodônticos. Foram descritas diversas técnicas de reforço de dentes anteriores e posteriores a partir de núcleos metálicos fundidos que poderiam evitar a ocorrência de fraturas radiculares. Em relação a coroa pivot o NMF apresentou as vantagens de ser independente da coroa permitindo reparos e trocas da mesma sem que houvesse necessidade de substituição de toda restauração e facilitou a obtenção do paralelismo entre pilares de uma prótese fixa.

BARABAN $^{9}$, em 1970, descreveu o sistema de pinos metálicos ParaPost utilizado tanto na técnica direta (núcleo em resina acrílica) quanto na indireta (NMF). Para ambas as técnicas o conduto foi preparado com uma broca correspondente ao calibre do pino selecionado. Os pinos eram fornecidos em cinco tamanhos e quatro materiais diferentes (ouro, aço 
inoxidável, alumínio e plástico). O sistema foi adequado para a maioria das raízes de dentes uniradiculares, desde que uma cuidadosa análise da morfologia radicular, clínica e radiográfica, fosse realizada.

A obtenção de núcleo de preenchimento com resina composta após cimentação de um pino pré-fabricado no conduto também foi descrita por FEDERICK ${ }^{20}$, em 1974, que considerou uma técnica precisa, econômica e adequada para diversas situações clínicas. A indicação de um pino e núcleo só seria necessária quando houvesse menos da metade da estrutura dentária remanescente de um dente despolpado.

Preocupados com a fratura de dentes tratados endodonticamente com rizogênese incompleta, RABIE et al. ${ }^{69}$, em 1985, descreveram uma técnica de ataque ácido e aplicação de resina através do relato de um caso clínico para o reforço e restauração destes dentes. A técnica foi descrita da seguinte maneira: sob isolamento relativo, um incisivo central superior teve um fio retrator posicionado no sulco gengival. Com o dente limpo, um bisel de 1-2 mm foi confeccionado. Removeu-se o material obturador até $3 \mathrm{~mm}$ apicais a crista óssea. O condicionamento com ácido fosfórico a 37\% foi realizado por 60 segundos no esmalte, na dentina da câmara pulpar e do conduto radicular. Após rinsagem e secagem do dente, a resina (P10-3M) foi injetada no conduto com uma seringa (Centrix) e forçada contra as paredes do mesmo. Um pino de aço inoxidável foi posicionado no conduto radicular, enquanto um segundo operador preencheu uma coroa de 
celulóide, pré-contornada, com a mesma resina, e imediatamente posicionou a mesma sobre a raiz antes da polimerização do material restaurador. A seguir a restauração foi recortada e polida. Afirmou-se que a resistência do dente à fratura na região cervical poderia ser aumentada com a utilização de resina composta como substituto dentinário.

Mais tarde, em 1986, RABIE; TROPE; TRONSTAND ${ }^{70}$ apresentaram nova técnica para reforçar dentes tratados endodonticamente com rizogênese incompleta que apresentavam paredes radiculares delgadas propensas a fraturas frente às forças mastigatórias. Foi descrito o tratamento de um incisivo superior, traumatizado e sem vitalidade. Antes dos procedimentos para a apicificação, a porção coronária da raiz, bem como a câmara pulpar era condicionada com ácido fosfórico e preenchida com resina composta aplicada através de seringa e condensada contra as paredes dentinárias. Um pino plástico (diâmetro de 1.5mm) lubrificado com vaselina era centralizado no interior do conduto radicular no comprimento pré-estabelecido. Após a polimerização da resina o pino era removido e criava-se um novo conduto. Para a apicificação, deixava-se $3 \mathrm{~mm}$ de hidróxido de cálcio no ápice coberto por uma fina camada de material restaurador provisório (IRM). Divulgou-se que esta técnica reforçaria com eficácia dentes nas condições apresentadas.

LUI ${ }^{43}$, em 1987, apresentou outra técnica cuja finalidade era a de reforçar raízes enfraquecidas. As causas citadas para o enfraquecimento 
radicular foram cárie, defeitos dentinários e iatrogenia. O reforço radicular tornaria o remanescente capaz de suportar uma restauração. A técnica descrita foi a seguinte: após o tratamento endodôntico dever-se-ia eliminar toda estrutura dentinária sem suporte preservando pelo menos $1 \mathrm{~mm}$ de remanescente dentinário necessário para uma margem supragengival. O preparo do conduto foi realizado com broca correspondente ao tamanho do mesmo preservando o selamento apical. Um fio metálico foi posicionado no interior do conduto e sua adaptação verificada clínica e radiograficamente. Prosseguiu-se com o condicionamento ácido e aplicação do sistema adesivo. O fio metálico lubrificado com vaselina foi posicionado para que a resina fosse injetada e condensada com instrumentos plásticos. Após a polimerização o fio foi removido criando-se um novo conduto para a cimentação de um pino. Através deste procedimento, acreditou-se que com uma camada suficiente de resina, a raiz debilitada seria reforçada possibilitando o suporte de um pino metálico em quase todas as situações onde este fosse requerido. Outra vantagem atribuída à técnica foi uma maior retentividade a partir da criação de um conduto mais paralelo e exato e por um procedimento simples.

GOODER; ZHUKOVSKY; BIVONA ${ }^{29}$ apresentaram, em 1994, um caso clínico de reabilitação de raízes com paredes delgadas utilizando resina fotopolimerizável. Atribuiu-se ao método usual de restauração de dentes fragilizados, através do NMF, um maior potencial de criar ações de cunha responsáveis por fraturas radiculares diante de cargas funcionais 
dinâmicas. Além disso, os núcleos metálicos poderiam interferir negativamente por transparência na aparência gengival. Como alternativa a este método, propô-se inicialmente o reforço interno de raízes fragilizadas com resina autopolimerizável. No entanto, esta técnica apresentou o problema da polimerização rápida da resina dificultando a inserção do pino. Tentou-se solucionar este problema com a utilização das resinas fotopolimerizáveis, porém havia a dificuldade de penetração da luz em áreas mais profundas do conduto. Como solução deste problema indicou-se a translucidação de todo o conduto através de um pino plástico fototransmissor (Luminex 2000). Assim, houve a possibilidade de reabilitar a porção radicular interna com resina composta estabelecendo um conduto com dimensões adequadas predeterminadas. O caso clínico foi descrito da seguinte maneira: preparou-se o espaço para o pino no comprimento desejado do dente 15, condicionou-se o mesmo e fotopolimerizou-se o adesivo através do pino fototransmissor; o canal foi preenchido com uma resina composta (Prisma) injetada com uma seringa Centrix e o pino translúcido vaselinado foi posicionado dentro do conduto no comprimento previamente determinado para que o material resinoso fosse uniformemente polimerizado por 60 segundos; o pino foi removido com movimentos de rotação e realizou-se fotopolimerização adicional por 20 segundos. Com um novo conduto em resina apresentando menor calibre, realizou-se a cimentação do NMF com o cimento C\&B Metabond. 
Em 1994, LUI ${ }^{45}$ descreveu uma técnica restauradora de condutos radiculares alargados utilizando resina fotopolimerizável através de pinos plásticos transmissores de luz (Luminex). Nestes condutos a falta de estrutura dentária remanescente dificultaria a utilização de pinos endodônticos. O uso de núcleos metálicos fundidos nestas situações poderia concentrar forças de cisalhamento, sobrecarregando a crítica porção coronária do conduto. Com a introdução dos materiais adesivos, tornou-se possível à reconstrução e reabilitação da estrutura dentinária perdida com resina composta preservando dentes severamente destruídos freqüentemente indicados à extração. A utilização de pinos plásticos transparentes permitiu que a resina composta fosse fotopolimerizada em áreas de difícil acesso da luz. Na técnica apresentada, após a medição do comprimento e diâmetro do conduto escolhia-se um pino de plástico translúcido de dimensões correspondentes ao canal em sua porção apical. Após o condicionamento ácido do interior radicular o adesivo aplicado era fotopolimerizado por 10 segundos com auxílio do pino plástico. Utilizou-se uma resina composta híbrida aplicada com uma seringa e acomodada com instrumentos plásticos. O pino plástico era reinserido até a profundidade marcada para garantir o comprimento desejado do futuro pino e ao mesmo tempo para facilitar a adaptação da resina contra as paredes radiculares. Eliminavam-se os excessos e a fonte de luz era posicionada na ponta externa do pino plástico para a fotopolimerização. O mesmo era removido por uma pinça hemostática e um novo conduto estabelecido com forma e dimensão mais adequada para o futuro pino. Concluiu-se que a reconstrução 
e o reforço de raízes debilitadas poderiam ser facilmente conseguidos através de resinas compostas fotopolimerizáveis com o auxílio de pinos plásticos fototransmissores.

Em 1996, ABDALLA; ALHAYDAINY ${ }^{1}$ avaliaram clinicamente o comportamento de três resinas compostas em restaurações classe I de prémolares. A resina Z-100 obteve o melhor desempenho considerando a integridade marginal, o manchamento marginal, descoloração e forma anatômica. Atribuiu-se a tal desempenho o alto conteúdo de carga incorporada à matriz, possivelmente devido ao tamanho e forma das suas partículas, que correspondem a $66 \%$ do seu volume. Este maior conteúdo de carga inorgânica permite uma maior resistência à compressão, dureza superficial e resistência ao desgaste. Além disso, acredita-se que pelo módulo de elasticidade da resina ser semelhante ao da dentina, o dente restaurado tem sua estrutura mais preservada frente às cargas oclusais.

OLIVEIRA JÚNIOR ${ }^{64}$, em 1997, apresentou uma descrição sobre o sistema Luminex e uma técnica de utilização do pino plástico transmissor de luz em dentes com raízes fragilizadas. A técnica consistia de: radiografia inicial, para se determinar o comprimento do conduto; remoção do material obturador; seleção do diâmetro do pino apropriado (variável de 1,05 a 1,80 $\mathrm{mm}$ ); preparo do espaço para o pino com alargadores do próprio sistema; condicionamento ácido e aplicação do sistema adesivo; posicionamento do pino e fotopolimerização do adesivo, preenchimento do conduto com resina 
e reposicionamento do pino fototransmissor lubrificado para fotopolimerização; remoção do pino plástico e cimentação do pino metálico com cimento resinoso; preparo do núcleo de preenchimento. Foram consideradas vantagens do sistema: a praticidade, a preservação da morfologia natural do conduto; a utilização de materiais resinosos; a diminuição do risco de fratura da raiz; o reforço de estruturas fragilizadas; a determinação de retenção máxima do pino pré-fabricado; a redução do tempo de trabalho e a diminuição do custo de tratamento.

FREDRIKSSON et al. ${ }^{25}$, em 1998, analisaram 236 dentes (130 superiores e 106 inferiores) restaurados com pinos de fibra de carbono (Compositpost), por um tempo clínico médio de 32 meses (27 a 41 meses). Avaliaram condições periodontais e protéticas, clínica e radiograficamente, iniciada logo após o tratamento. Cinco dentes (2\%) foram extraídos por razões não relacionadas aos pinos (doença periodontal severa). As condições periodontais (índice de placa, sangramento à sondagem e profundidade de bolsa) dos dentes com pinos de fibra de carbono foram similares as dos dentes controle (contra laterais ou similares em anatomia e posição). Não se registrou nenhum caso de deslocamento do pino ou das restaurações, nem fratura das raízes ou pinos. Os resultados mostraram-se promissores para a utilização dos pinos de fibra de carbono como alternativa viável ao NMF. 
LUI ${ }^{46}$, em 1999, numa descrição de caso clínico, abordou o aumento da retenção de pinos em raízes debilitadas reforçadas com resina composta. A reconstrução do tecido dentinário perdido através da técnica adesiva, não só reforçaria o dente comprometido, como também criaria um conduto paralelo e mais retentivo. Isto representaria uma vantagem sob os núcleos metálicos fundidos convencionais que, apesar de apresentarem uma boa adaptação, possuem uma forma cônica que tende a diminuir a resistência da raiz à fratura quando comparados aos pinos paralelos. Relatou-se o tratamento de um paciente de vinte quatro anos que apresentava dois incisivos superiores com paredes radiculares delgadas. Cada dente foi restaurado por uma técnica. Um incisivo foi restaurado com resina composta híbrida fotopolimerizável, auxiliada por um pino plástico transmissor de luz (Luminex), e NMF. O outro foi preparado para receber um NMF pela técnica convencional. Os núcleos foram provados, adaptados e cimentados com cimento de ionômero de vidro. Feitas as radiografias pós-cimentação, as coroas metalocerâmicas foram cimentadas. Quatro meses depois, o paciente retornou com a coroa sobre o dente restaurado pela técnica convencional (NMF sem reconstrução com resina) deslocada. O cimento antigo foi removido e a mesma coroa foi novamente cimentada. Cinco meses depois, mais uma vez o paciente retornou com a coroa deslocada. Desta vez optou-se restaurar o incisivo da mesma forma que o vizinho (NMF com preenchimento radicular com resina) com a cimentação de uma nova coroa metalocerâmica. Acompanhou-se a mesma por um período de três anos sem qualquer deslocamento. Concluiu-se que raízes reforçadas poderiam 
acomodar passivamente pinos bem adaptados com paredes paralelas que aumentariam sua retenção de maneira mais adequada do que pinos em condutos amplos e expulsivos.

AQUILINO; CAPLAN ${ }^{7}$, em 2002, testaram a hipótese de que a utilização de uma coroa estivesse associada a melhores índices de sobrevivência de dentes tratados endodonticamente. Somente incluiu-se no estudo pacientes que fizeram pelo menos uma visita ao dentista (faculdade) a cada intervalo de dois anos no período entre 1985-1996. Foram analisados 203 dentes em 156 pacientes. Destes, 95 foram restaurados com pinos préfabricados ou núcleos e 108 receberam restaurações de amálgama, resina composta ou ionômero de vidro sem pino. Após terapia endodôntica, utilizouse coroa em 129 dentes, enquanto que em 74 dentes realizaram-se restaurações definitivas de amálgama ou resina composta. Após análises estatísticas verificou-se que os dentes tratados endodonticamente com coroas tiveram melhores taxas de sobrevivência do que aqueles sem o recobrimento coronário total. Outros fatores significativamente associados foram: quantidades de contatos proximais (distribuição de forças oclusais), presença de cárie no momento do acesso endodôntico, restauração com pino e momento da restauração após obturação. A utilização de coroa sobre estes dentes alcançou um índice de sobrevivência seis vezes maior do que aquele encontrado para as restaurações diretas. A presença da coroa foi considerada mais importante do que o tipo de pino e núcleo utilizado. 
MALFERRARI; MONACO; SCOTTI $^{48}$, em 2003, avaliaram prospectivamente o comportamento clínico de pinos resinosos reforçados por fibras de quartzo utilizados em dentes tratados endodonticamente por um período de 30 meses. Em cento e trinta e dois pacientes, 180 dentes tratados endodonticamente foram restaurados usando pinos de fibra de quartzo (Aestheti-Plus). Os pinos foram cimentados com o sistema adesivo All- Bond 2 (auto-polimerizável) e o cimento resinoso C \& B (autopolimerizável). O núcleo de preenchimento foi feito com Core-Flo ou BisCore e coroas de cerâmica pura ou metalocerâmicas foram aplicadas como restaurações finais. Os parâmetros considerados como falhas clínicas foram: deslocamento, descimentação ou fratura dos pinos; fratura radicular ou do núcleo e descimentação da coroa ou prótese. Os pacientes foram avaliados após 6, 12, 24 e 30 meses do final das restauração. Uma falha coesiva envolvendo a margem do núcleo de resina composta foi observada após duas semanas e duas fraturas adesivas foram vistas após dois meses. Estas falhas localizaram-se entre o cimento e as paredes dentinárias dos canais. Todas as três falhas ocorreram durante a remoção da coroa provisória. O percentual de falhas foi de 1,7\% num período de 30 meses. As falhas foram passíveis de substituição por nova restauração com sucesso nos três casos. Por um período superior a 30 meses a reabilitação de dentes tratados endodonticamente usando pinos de fibra de quartzo mostrou bons resultados clínicos. Nenhuma descimentação de coroa ou prótese foi observada e nenhuma fratura de pino, núcleo ou raiz foi registrada. 
MONTICELLI et al. ${ }^{58}$, em 2003, avaliaram prospectivamente por um período 2 anos o comportamento clínico de três tipos de pinos considerados transluzentes. Foram selecionados 225 pacientes com necessidade de tratamento endodôntico em pré-molar restaurado posteriormente com um pino de fibra e com uma coroa em porcelana. A amostra foi aleatoriamente dividida em três grupos com 75 pacientes. O mesmo tipo de pino foi utilizado em todos os pacientes dentro de um mesmo grupo: gl- fibra de carbono envolta por quartzo (Aesthetic Plus); gll- fibra de quartzo (Dual Tapper Light post-DT); e glll- fibra de vidro (FRC Postec). Para a adesão dos pinos, um adesivo fotopolimerizável (One-Step) e um cimento dual (Duo-Link) foram aplicados nos grupos I e II, enquanto que materiais de polimerização química (adesivo Excite DSC e cimento resinoso Multi Link) foram utilizados no grupo III. Após 6, 12 e 24 meses os pacientes foram avaliados clinica e radiograficamente. A decimentação dos pinos ocorreu em oito casos $(3,5 \%)$ e em outros seis casos o reaparecimento de lesões periapicais foi registrado. A análise estatística não revelou qualquer diferença significativa no percentual de sobrevivência dos pinos testados, sugerindo que todos podem ser utilizados clinicamente com segurança. 
3 - PROPOSICÃO 


\section{3 - PROPOSIÇÃO}

Como base na revisão de literatura não se verificou em qualquer investigação laboratorial a utilização de resina composta e pino de fibra de vidro na restauração de raízes fragilizadas. Portanto, objetivou-se com este trabalho avaliar:

A existência de diferença de resistência à fratura entre raízes conforme grau de fragilização dentinária;

$>$ A existência de correlação entre a fragilização dentinária e a localização da fratura bem como o prognóstico restaurador. 
4 - MATERIAL E MÉTODOS 


\section{4 - MATERIAL E MÉTODOS}

Previamente à realização do trabalho propriamente dito realizou-se um estudo piloto utilizando 10 dentes caninos com o propósito de criar, aperfeiçoar e padronizar as diferentes técnicas laboratoriais.

\section{1- Material}

Para a realização desta pesquisa utilizou-se o material descrito na tabela 4.1

Tabela 1 - Material utilizado na pesquisa

\begin{tabular}{|c|c|c|}
\hline MATERIAL & NOME COMERCIAL & FABRICANTE \\
\hline Disco diamantado & KG Sorensen & $\begin{array}{l}\text { KG Sorensen, Ind. Com. } \\
\text { Ltda., São Paulo- } \\
\text { SP,Brasil }\end{array}$ \\
\hline $\begin{array}{l}\text { Paquímetro digital com } \\
\text { resolução } 0,1 \pm 0,2 \mathrm{~mm} \text {. }\end{array}$ & $\begin{array}{l}\text { MITUTOIO SC-6" - } \\
\text { COOE TOO-113 }\end{array}$ & $\begin{array}{l}\text { Mitutoyo Corporation, } \\
\text { Japan }\end{array}$ \\
\hline $\begin{array}{l}\text { Lupa frontal quatro } \\
\text { aumentos }\end{array}$ & Lupa Bio-Art $4 \mathrm{X}$ & $\begin{array}{l}\text { Bio-Art, Equipamentos } \\
\text { Odontológicos, São } \\
\text { Carlos, SP, Brasil }\end{array}$ \\
\hline $\begin{array}{c}\text { Solução isotônica de } \\
\text { cloreto de sódio a } 0,9 \% \\
\text { com cristais de timol a } \\
0,1 \%\end{array}$ & & $\begin{array}{l}\text { Farmácia Farina- } \\
\text { Manipulações, Bauru, SP }\end{array}$ \\
\hline $\begin{array}{l}\text { Solução isotônica de } \\
\text { cloreto de sódio a 0,9\% }\end{array}$ & & $\begin{array}{c}\text { Farmácia Farina- } \\
\text { Manipulações, Bauru, SP }\end{array}$ \\
\hline Hipoclorito de Sódio $2,5 \%$ & Biodinâmica & $\begin{array}{c}\text { Biodinâmica Química e } \\
\text { Farmacêutica, Ibiporã - } \\
\text { PR, Brasil }\end{array}$ \\
\hline Limas endodônticas & Hedstrom,K-file & $\begin{array}{l}\text { Maillefer- Dentsply, } \\
\text { Petrópolis, RJ, Brasil }\end{array}$ \\
\hline $\begin{array}{l}\text { Cones de papel } \\
\text { absorvente }\end{array}$ & Endopoints & $\begin{array}{c}\text { Endopoints, Ind. e } \\
\text { Com.,Paraíba do Sul, RJ, } \\
\text { Brasil ; Lote: } 7554\end{array}$ \\
\hline $\begin{array}{l}\text { Cones de guta percha } \\
\text { primário e secundário }\end{array}$ & Endopoints & $\begin{array}{c}\text { Endopoints, Ind. e } \\
\text { Com.,Paraíba do Sul, RJ, } \\
\text { Brasil ; Lote: } 7325 ; 7453\end{array}$ \\
\hline Cimento endodôntico & Sealer AH 26 & $\begin{array}{c}\text { Dentsply, Petrópolis, RJ, } \\
\text { Brasil; Lote: } 72021\end{array}$ \\
\hline Delineador & Delineador Bio-Art & $\begin{array}{l}\text { Bio-Art, Equipamentos } \\
\text { Odontológicos, São }\end{array}$ \\
\hline
\end{tabular}

Continua... 
Carlos, SP, Brasil

$\begin{array}{cc}\begin{array}{c}\text { Cilindro de PVC }-1 / 2 \\ \text { polegada }\end{array} & \text { Tigre } \\ \begin{array}{c}\text { Resina acrílica auto- } \\ \text { polimerizável }\end{array} & \text { Duralay } \\ \begin{array}{c}\text { Resina acrílica } \\ \text { autopolimerizável }\end{array} & \text { Jet } \\ \end{array}$

\begin{tabular}{cc}
\hline Broca de Peeso & Angelus \\
\hline Pontas diamantadas & $1016,3017 \mathrm{HL}, 3018 \mathrm{HL}$ \\
\hline
\end{tabular}

Solução detergente

Ponta aplicadora descartável

Pino de plástico

fototransmissor $n^{\circ} 5$

Sistema adesivo

fotopolimerizável

Sistema adesivo de

polimerização química

Resina composta híbrida

fotopolimerizável

Cimento resinoso de

polimerização dupla

Luminex System

Scotchbond Multi-Uso

Aparelho

fotopolimerizador

Ácido fosfórico a $37 \%$

Ceramic Primer-Silano

Broca lentulo

Pino de fibra de vidro

Matrizes de acetato

Plastificadora a vácuo
Tergensol

Microbrush

Single Bond

Filtek Z250

RelyX ARC

Reforpost

Bio-Art

Plastivac

Tigre do Brasil, Osasco, SP, Brasil

Reliance Dental Mfg. Co.

Chicago, III, USA

Artigos Odontológicos

Clássicos LTDA, São

Paulo-SP, Brasil

Angelus, Londrina, PR, Brasil

KG Sorensen, Ind. Com.

Ltda., São PauloSP,Brasil

Inodon Laboratório, Porto

Alegre, RS, Brasil

Microbrush, Corporation, Grafton- USA

Dentatus Ltd, New York, NY, USA

$3 \mathrm{M}$, Sumaré, SP, Brasil

$3 \mathrm{M}$, Sumaré, SP, Brasil

3M, Sumaré, SP, Brasil

3M, Sumaré, SP, Brasil; Lote: CREA

Dabi Atlante, Ribeirão

Preto, SP, Brasil

Scotchbond $\quad 3 \mathrm{M}$, Sumaré, SP, Brasil;

Lote: 3BK

$3 \mathrm{M}$, Sumaré, SP,

Brasil;Lote: $3 \mathrm{UJ}$

Maillefer- Dentsply,

Petrópolis, RJ, Brasil

Angelus, Londrina, PR, Brasil

Bio-Art, Equipamentos

Odontológicos, São

Carlos, SP, Brasil

Bio-Art, Equipamentos

Odontológicos, São

Carlos, SP, Brasil

Bio-Art, Equipamentos

Odontológicos, São

Carlos, SP, Brasil 
Continuação

Sonda periodontal

Espátula de inserção

Pingador de cera

Silicona de adição especial para duplicação

Cera opaca para escultura

Seringa hipodérmica de vidro $\mathrm{n}^{\circ} 10$

Fio de cera
SS White

SS White

Elite Doublé 8-

Cera Rainbow

Babinete

Verabond II

Talladium

Tigre

KG Sorensen

Broca de aço esférica $n^{\circ} 02$

Liquido evidenciador de contato

Máquina de simulação de ciclos mecânicos

Máquina de ensaios universal
Hu-friedy Inc, Chicago, III, USA

SS White, Rio de Janeiro, RJ, Brasil

SS White, Rio de Janeiro, RJ, Brasil

Zhermack -Badio

Polesine- Rovigo- Italy

Porto Ferreira, SP, Brasil Lote: (RH-01) 201

B-D Juiz de Fora, MG, Brasil

Ind. e Com. de Ceras Babinete-Ltda, São Paulo, SP, Brasil AALBA Dent Inc., Califórnia, USA

Talladium Inc, California, USA

Tigre do Brasil, Osasco, SP, Brasil

KG Sorensen, Ind. Com. Ltda., São PauloSP,Brasil

Farmingdale, New Jersey, USA Engenheiro Marcelo Nucci, São Carlos- SP Dinamômetros Kratos, São Paulo, SP, Brasil

\section{2 - Seleção dos dentes, limpeza e armazenamento}

Foram selecionados 30 caninos humanos superiores íntegros, com anatomia e dimensões aproximadamente semelhantes, com comprimentos radiculares entre 16 e $18 \mathrm{~mm}$. Estes foram coletados em clínicas públicas de pronto atendimento da cidade de Bauru. Este procedimento foi realizado mediante autorização livre e esclarecida dos pacientes (Anexo II) conforme exigência do Comitê de Ética em pesquisa da Faculdade de Odontologia de Bauru, cuja carta de aprovação encontra-se anexada (Anexo I). Os dentes 
foram raspados com cureta, seccionados num comprimento padronizado de $14 \mathrm{~mm}$ com discos diamantados ${ }^{52}$ e armazenados em solução antifúngica isotônica de cloreto de sódio a $0,9 \%$ com cristais de timol a $0,1 \%$ até sua utilização ${ }^{33}$.

\section{3 - Tratamento endodôntico}

O comprimento de trabalho na instrumentação dos condutos foi determinado através da utilização de uma lima número 10 tipo K-file até o seu aparecimento no forame apical. A partir deste comprimento foi subtraído $1 \mathrm{~mm}$ e os canais instrumentados através da técnica escalonada regressiva até a lima número 40 tipo K-file na constricção apical. Os canais foram irrigados com uma solução de hipoclorito de sódio a $2,5 \%^{33,59,78}$ e secos cones de papel absorvente. Os condutos foram obturados através da técnica de condensação lateral, utilizando-se de um cone de guta percha principal número 40 e cones secundários com cimento endodôntico resinoso ${ }^{33,78}$. Após obturação dos condutos as raízes foram então novamente armazenadas em solução fisiológica.

\section{4 - Montagem dos corpos de prova}

Os remanescentes radiculares foram posicionados e fixados dentro de cilindros de PVC de $1 / 2$ polegada com $20 \mathrm{~mm}$ de altura. A centralização das raízes no interior dos cilindros foi conseguida pela utilização de um delineador, mantendo-se uma exposição radicular de 3mm (figura 1). 


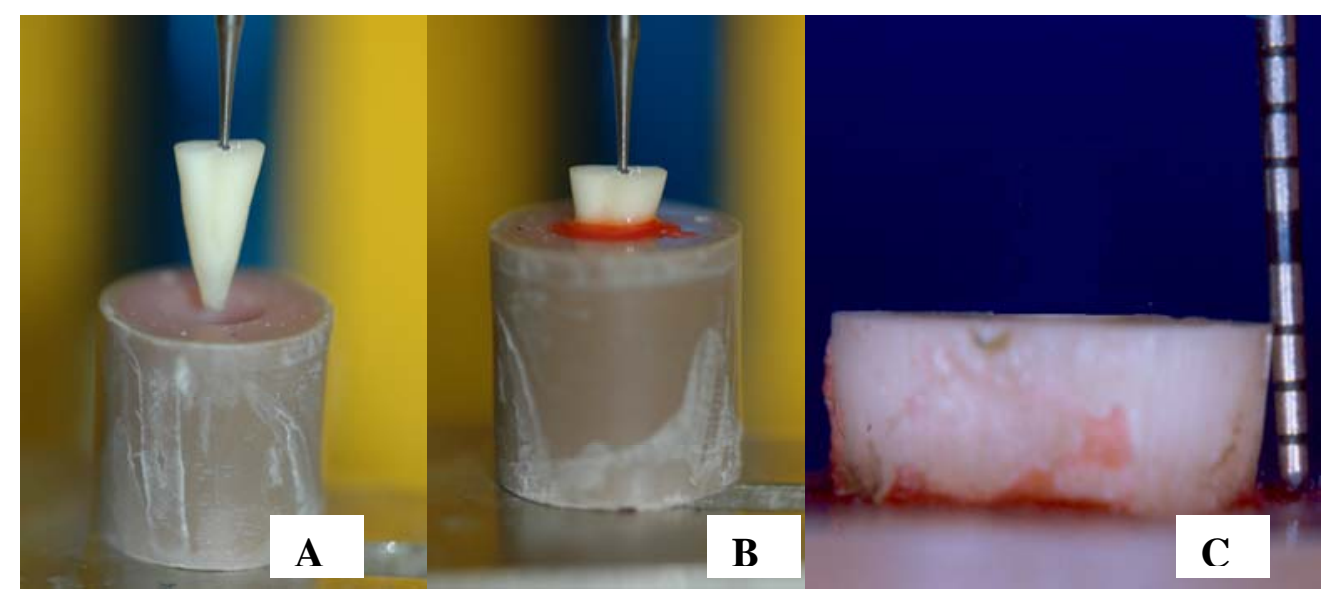

Figura 1 - (A) Inserção do dente seguindo o longo eixo do cilindro de PVC e resina acrílica (B) Fixação do dente com resina Duralay (C) Espaço de 3,0 mm simulando as distâncias biológicas

Após a polimerização da resina, todos os corpos de prova foram identificados e mantidos em solução fisiológica no interior de recipientes hermeticamente fechados.

\section{5 - Constituição dos grupos}

Após a obtenção dos corpos de prova, estes foram aleatoriamente divididos em três grupos e submetidos a diferentes quantidades de desgaste ${ }^{51,52}$, para simulação de raízes fragilizadas, sendo classificados segundo a condição de remanescente radicular no sentido horizontal em (figura 2):

Grupo I: raiz íntegra restaurada com pinos resinosos reforçados com fibra de vidro e porção coronária restaurada com resina composta; 
Grupo II: raiz parcialmente fragilizada reconstruída com resina composta, pinos resinosos reforçados com fibra de vidro e porção coronária restaurada com resina composta;

Grupo III: raiz amplamente fragilizada reconstruída com resina composta, pinos resinosos reforçados com fibra de vidro e porção coronária restaurada com resina composta.

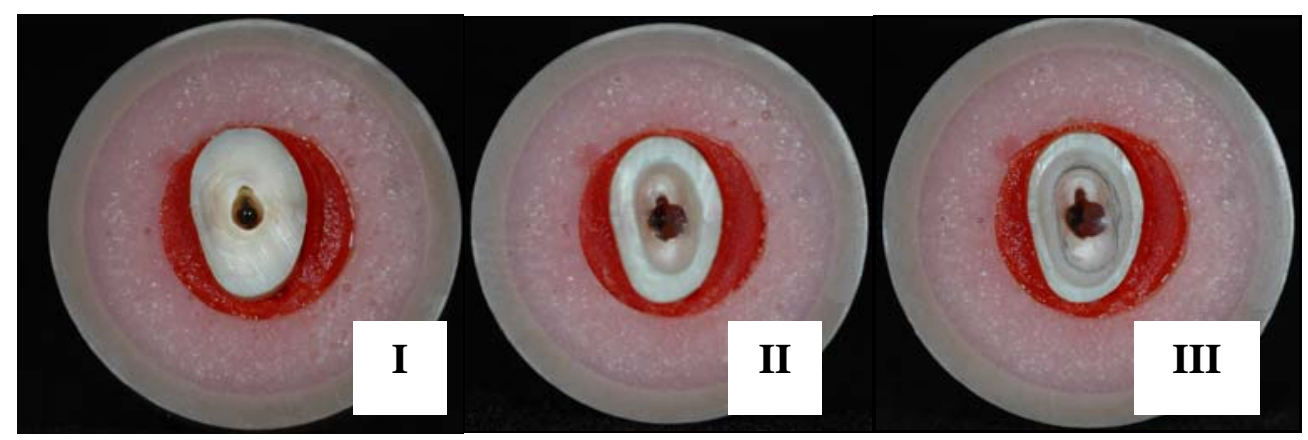

Figura 2 - Representações de raízes com diferentes espessuras de remanescentes radiculares classificadas em: (grupo I) íntegras, (grupo II) parcialmente fragilizadas e (grupo III) amplamente fragilizadas

\section{6 - Preparo das raízes}

Para o preparo das raízes do grupo I, a remoção de guta-percha do conduto foi feita até profundidade de $9 \mathrm{~mm}$, inicialmente com uma ponta Rhein número 1 aquecida, seguida de utilização de broca de Peeso número 5 do kit do pino (1,5mm de diâmetro) (figura 3 ) utilizado em baixa rotação 
sob refrigeração. Após o término do preparo verificou-se, por meio de espessímetro, uma espessura remanescente de aproximadamente $2 \mathrm{~mm}$ de parede dentinária no terço cervical.

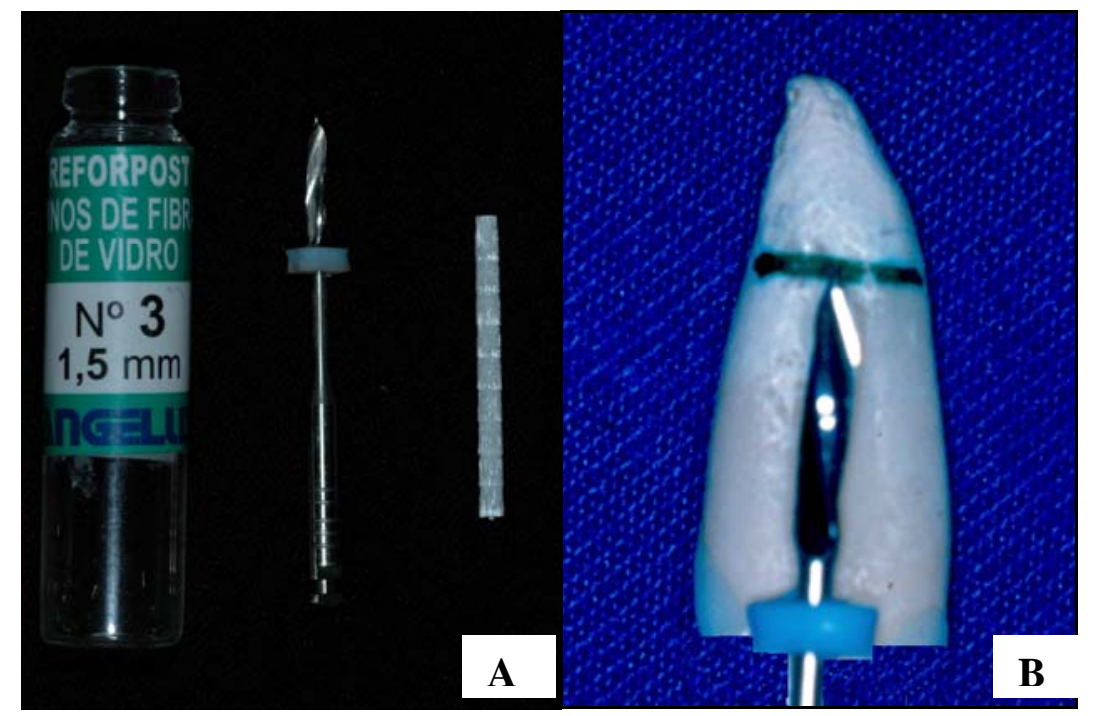

Figura 3 - (A) Pino $\mathrm{n}^{\circ} 3$ (1,5 mm de diâmetro) com respectiva broca de Peeso número 5 (B) Representação da profundidade desgastada

O preparo que simulou raízes parcialmente fragilizadas (grupo II), foi realizado através de desgastes com pontas diamantadas inicialmente em alta rotação terminando em baixa rotação sob refrigeração constante. Primeiramente foi realizado um desgaste de $9 \mathrm{~mm}$ de profundidade até o terço apical, com ponta diamantada esférica número 1016 (1,8mm diâmetro) (figura 4 A). Em seguida, foi realizado um segundo desgaste do terço cervical até o terço médio alcançando $5 \mathrm{~mm}$ de profundidade com a ponta diamantada esférica número 3017 HL (2,5mm de diâmetro) (figura 4 B). Ao 
final do preparo, as paredes dentinárias remanescentes apresentavam $1 \mathrm{~mm}$ de espessura, controladas por espessímetro (figura 5 B).

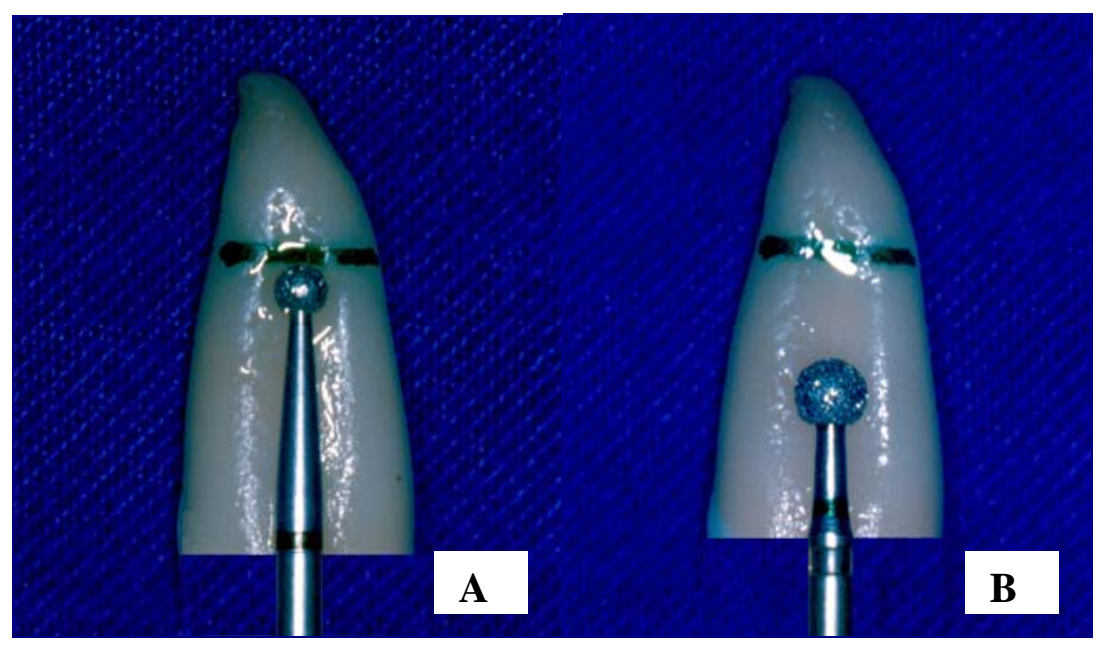

Figura 4 - (A) Ponta diamantada 1016 utilizada no primeiro desgaste até a profundidade de $9 \mathrm{~mm}$ (B) Ponta diamantada $3017 \mathrm{HL}$ utilizada no segundo desgaste até a profundidade de $5 \mathrm{~mm}$ alcançando o terço médio

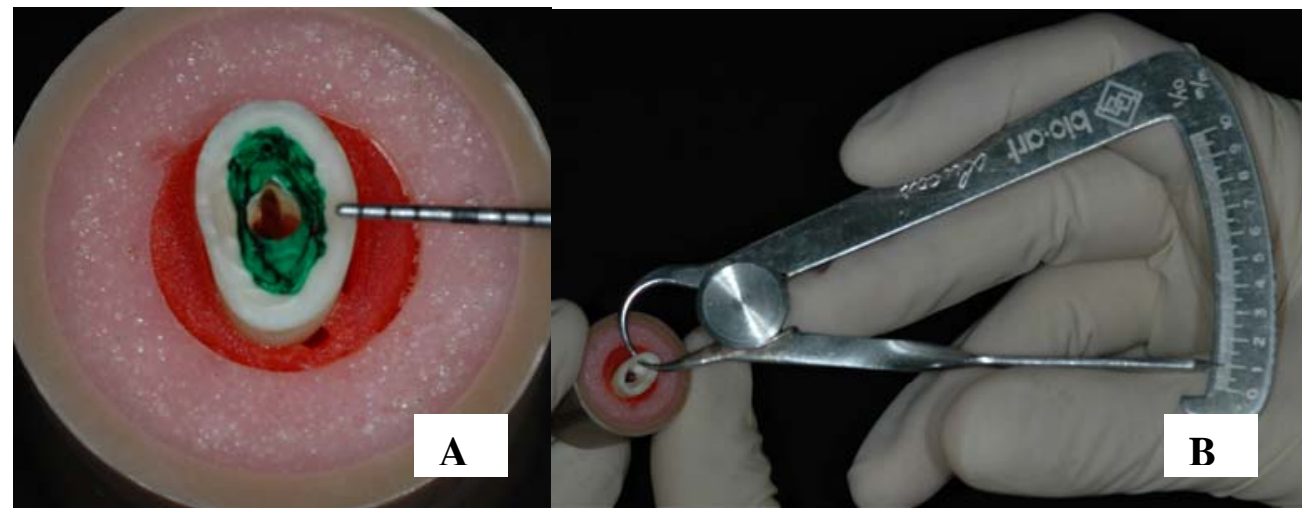

Figura 5 - (A) Controle da espessura dentinária a ser desgastada através de demarcação prévia com marcador permanente verde e (B) após desgaste com espessímetro 
Para o preparo das raízes que simularam condutos amplamente fragilizados (grupo III), foram utilizados três pontas diamantadas de diâmetros diferentes. Os desgastes dos terços apical e médio foram realizados da mesma forma descrita anteriormente e com uma ponta diamantada esférica número 3018HL (3mm de diâmetro), foi realizado um terceiro desgaste no terço cervical com $3 \mathrm{~mm}$ de profundidade de maneira a deixar uma parede dentinária remanescente de $0,5 \mathrm{~mm}$ de espessura (figura $6)$.

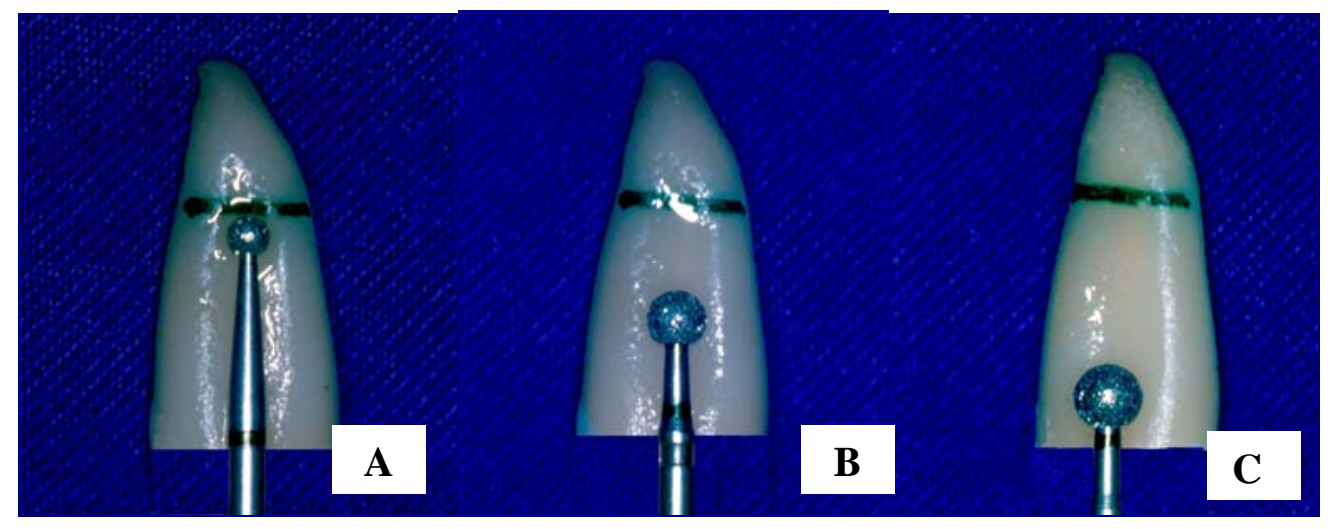

Figura 6 - Pontas diamantadas utilizadas no grupo III, com as respectivas profundidades de desgaste: (A) 1016, 9mm de profundidade até o terço apical (B) $3017 \mathrm{HL}, 5 \mathrm{~mm}$ de profundidade até o terço cervical (C) $3018 \mathrm{HL}, 3 \mathrm{~mm}$ de profundidade até o terço cervical 
A profundidade de penetração das pontas diamantadas foi controlada através de marcações em suas hastes e também por sonda periodontal (figura 7).

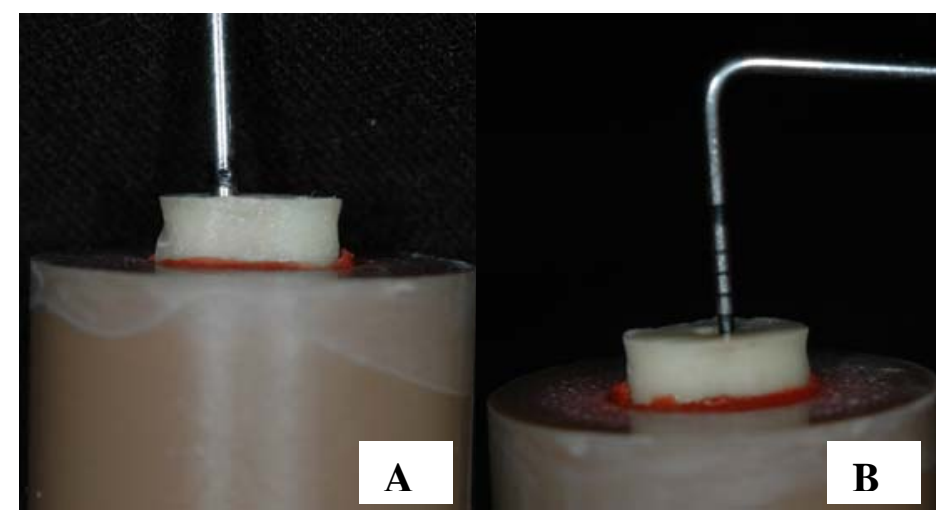

Figura 7 - (A) Marcação feita na ponta diamantada (B) Sonda periodontal controlando a profundidade de desgaste

Para melhor visualização dos preparos das raízes segue esquema a seguir: (figura 8 )

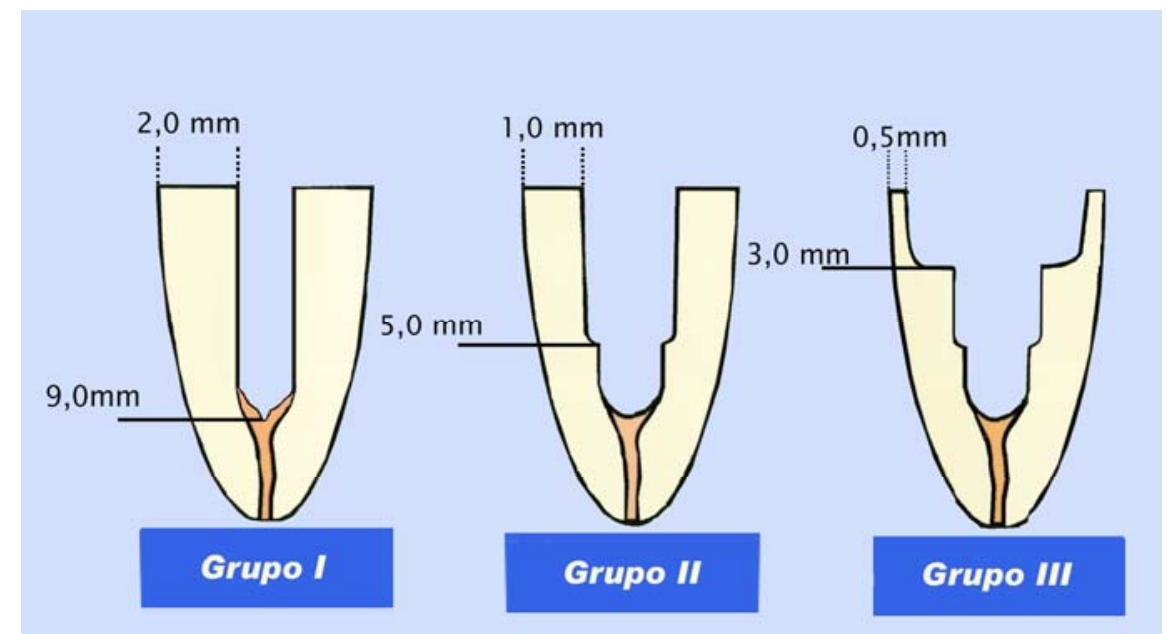

Figura 8 - Profundidades e espessuras de desgastes realizados em cada grupo 


\section{7 - Reconstrução das raízes fragilizadas}

Após o preparo dos remanescentes radiculares, as raízes foram irrigadas com solução detergente e jatos de água para limpeza de eventuais impurezas, secas com cones de papel absorvente e tiveram seus condutos condicionados com ácido fosfórico a 37\% por 15 segundos, removidos com jatos de água por 30 segundos através de seringa tríplice e hipodérmica mais cânula. O excesso de umidade foi removido com cones de papéis absorventes para se evitar o ressecamento da dentina. A aplicação do sistema adesivo fotopolimerizável foi feita por ponta aplicadora descartáveis auxiliada por um pino plástico fototransmissor número $5(1,65 \mathrm{~mm}$ de diâmetro) posicionado com ligeira folga lateral de maneira atingir toda profundidade do conduto preparado. O excesso de adesivo foi removido com ponta de papel absorvente. Com a ponta do aparelho fotopolimerizador direcionada no extremo do pino fototransmissor, foi realizado a fotopolimerização por 10 segundos. Em seguida, as raízes enfraquecidas foram preenchidas com resina composta híbrida aplicada dentro do conduto com auxílio de uma espátula para resina e um pingador de cera número 2. Incrementos de 1,5 $\mathrm{mm}$ foram aplicados e fotopolimerizados um a um, por 20 segundos, iniciando desde a porção mais interna até o preenchimento completo da raiz. (figura 9). 


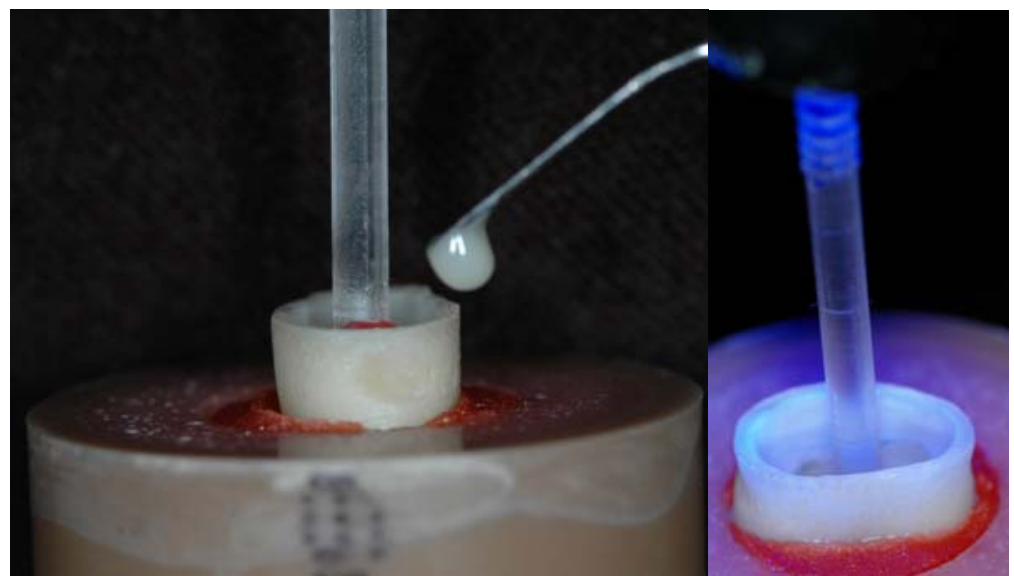

Figura 9 - Incremento de resina composta aplicado dentro do conduto com espátula para resina e fotopolimerização com auxílio do pino plástico fototransmissor

Junto de cada incremento condensado, estava o pino fototransmissor, introduzido até a profundidade de $9 \mathrm{~mm}$, verificando-se sempre a centricidade do mesmo. Com a resina polimerizada o pino foi retirado com o auxílio de um alicate e se observou a diminuição da luz do conduto (figura 10).

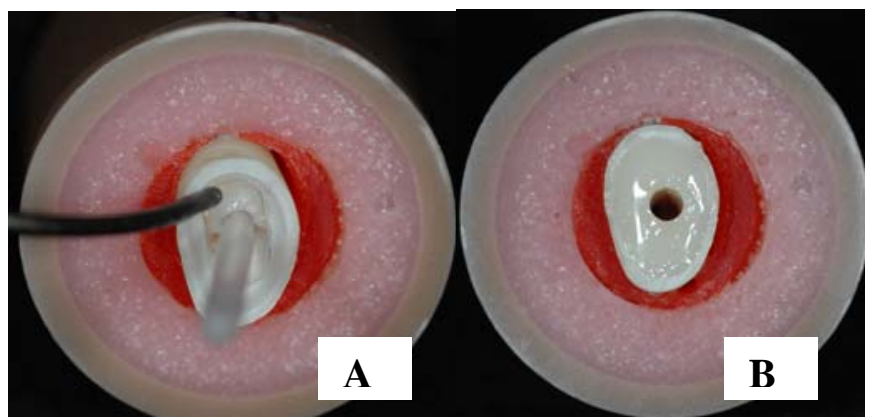

Figura 10 - (A) Preenchimento do conduto desde sua porção mais apical com auxílio de pingador de cera (B) Novo conduto obtido 


\section{8 - Cimentação dos pinos}

A cimentação dos pinos foi iniciada pela adaptação dos mesmos ao comprimento de 9mm intra-radicular e mais uma extensão coronária de $3 \mathrm{~mm}$ delimitada com um marcador permanente. O corte do pino foi realizado com disco diamantado ${ }^{30}$, sob refrigeração e a limpeza do mesmo feita com álcool. A partir desse momento seu manuseio foi realizado através de pinça clínica. Foi aplicado uma camada de agente silano seca com jato de ar por 5 segundos ${ }^{4}$. Realizado os cuidados com o pino, o conduto foi condicionado com ácido fosfórico a $37 \%$ por 15 segundos, com o auxílio de uma seringa luer e cânula até o seu preenchimento total, lavado com água e o excesso de umidade removido com cones de papel absorvente. Aplicou-se o sistema adesivo quimicamente polimerizável convencional de três passos. Seguindo passo a passo as orientações do fabricante, primeiramente o ativador do sistema foi aplicado com cones de papel no canal por 5 segundos. Em seguida, da mesma forma o primer. Por último aplicou-se o catalisador. Imediatamente após estas três etapas, partes iguais da pasta base e catalisadora do cimento resinoso de polimerização dupla, previamente separadas sobre papel de espatulação, foram misturadas, aplicadas sobre o pino e levadas ao conduto por uma broca lentulo ${ }^{27}$ sob baixa rotação. $O$ pino foi assentado passivamente no conduto sob pressão digital e o excesso de cimento removido seguindo a fotopolimerização de cada face por 40 segundos (figura 11). 


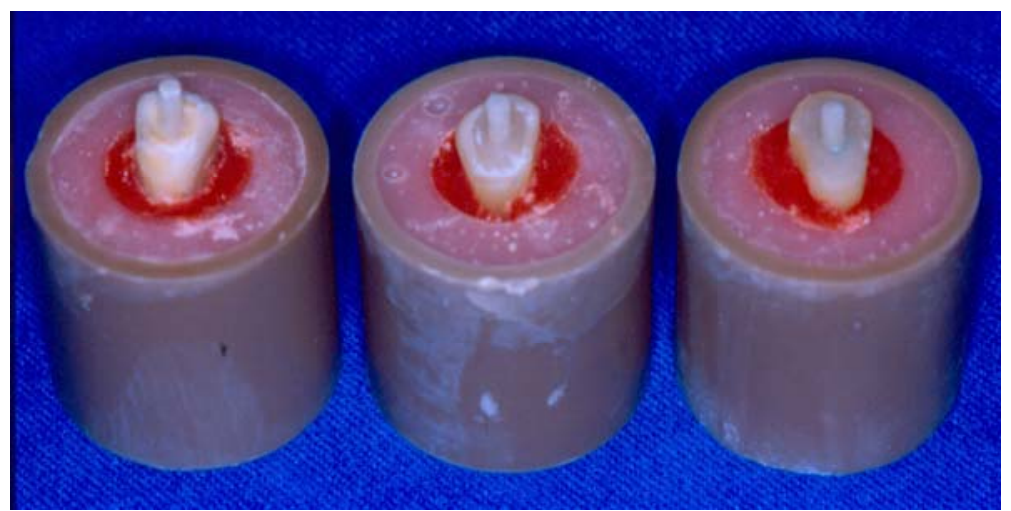

Figura 11 - Pinos cimentados após fotopolmerização do cimento

\section{9 - Construção da porção coronária}

Para padronizar a confecção da porção coronária dos núcleos de preenchimento foi confeccionado uma matriz em Ni-Cr com quatro padrões metálicos obtidos a partir da fundição de um modelo de canino superior previamente preparado para receber uma coroa total metálica (figura 12).

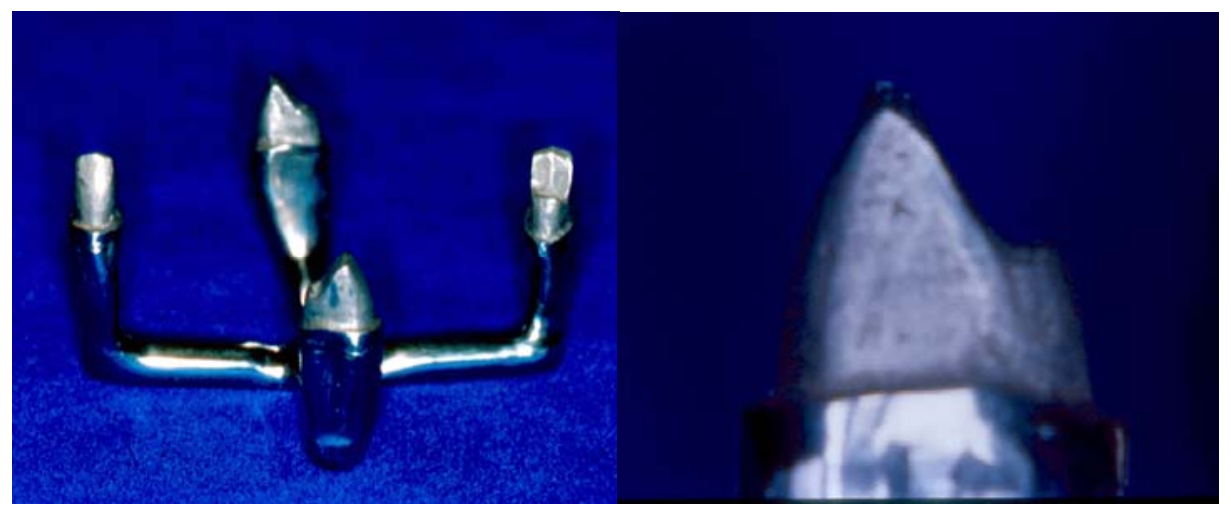

Figura 12 - Matriz e padrão metálico

A partir deste padrão metálico, foram reproduzidas matrizes de acetato em uma máquina plastificadora a vácuo que serviram para auxiliar a confecção dos núcleos de preenchimento em resina composta híbrida ${ }^{59}$. 
Tais matrizes foram adaptadas a cada espécime. Incrementos de resina composta foram aplicados e fotopolimerizados ao redor do pino num volume suficiente para que se criasse base do futuro núcleo sem que houvesse interferência da matriz de acetato. .A seguir, a forma externa dos núcleos foi obtida a partir do preenchimento da matriz com resina composta e posicionamento da mesma sobre os espécimes para remoção do excesso de material extravasado antes da fotopolimerização final.

Após a fotopolimerização do material realizou-se remoção de pequenos excessos de resina sem suporte com lâmina de bisturi. Ao final da reconstrução os núcleos apresentaram uma altura de aproximadamente $6 \mathrm{~mm}$ (figura 13).

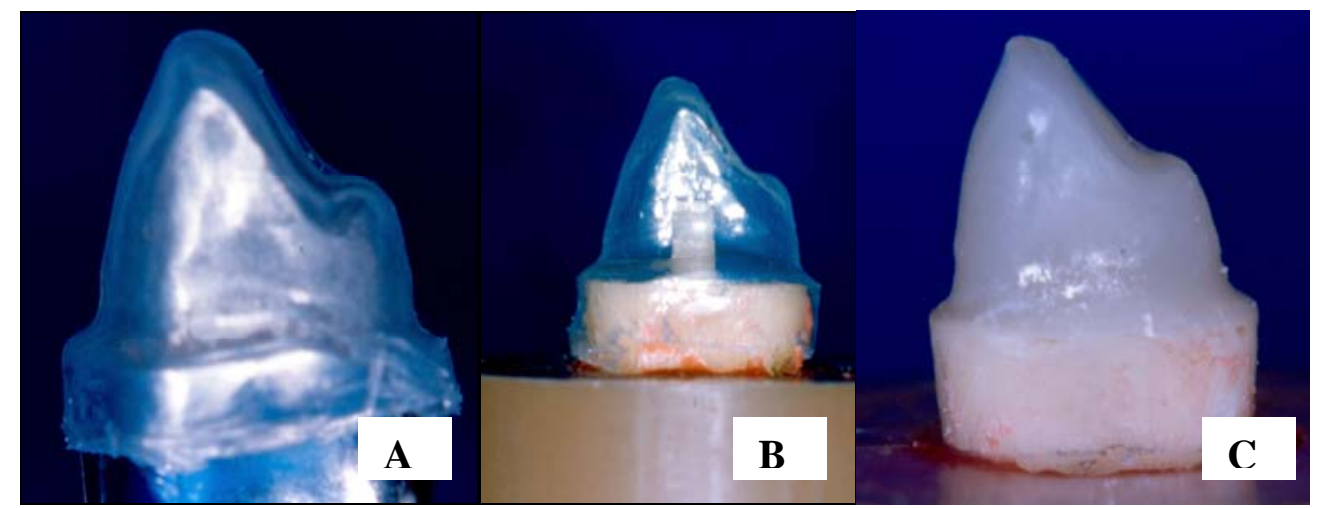

Figura 13 - (A) Matriz de acetato a partir de padrão metálico (B) Matriz adaptada para confecção dos núcleos (C) Núcleo em resina composta obtido pela matriz

\subsection{0 - Confecção das coroas totais metálicas}

Os núcleos de preenchimento foram vaselinados para o enceramento das trinta coroas, com uma escultura padronizada através da cópia de um canino superior natural íntegro, estabilizado no interior do cilindro de PVC na 
mesma posição dos espécimes (figura 14 A e figura 15 A). Sobre sua ponta de cúspide foi fixado um conduto de alimentação em cera de $3 \mathrm{~mm}$ de diâmetro para que na aplicação da cera pudesse haver uma comunicação do meio externo com a porção interna do molde (figura 14 A). A moldagem deste conjunto (corpo de prova/ coroa íntegra/ fio de cera) foi realizada com silicona de adição especial para duplicação (figura 14 B). O molde obtido (figura $14 \mathrm{C}$ ) pode então, ser acoplado aos demais corpos de prova com as porções coronárias preparadas para a aplicação da cera. Tal aplicação foi realizada a partir do aquecimento da cera em dispositivo que permitisse fluidez suficiente para que fosse aspirada com uma seringa hipodérmica de vidro aquecida e em seguida aplicada no conduto do molde (figura $14 \mathrm{D}$ ). Após o endurecimento da cera, o molde foi removido e cada padrão de cera tinha seus excessos removidos na área cervical a partir do término copiado (figura 15 B). Sobre a superfície palatina, no terço incisal, foram fixados fios de cera de 0,5 mm de diâmetro, para que a ponta ativa da máquina de ciclagem mecânica fosse direcionada para o centro da mesma superfície (figura $15 \mathrm{C}$ ).

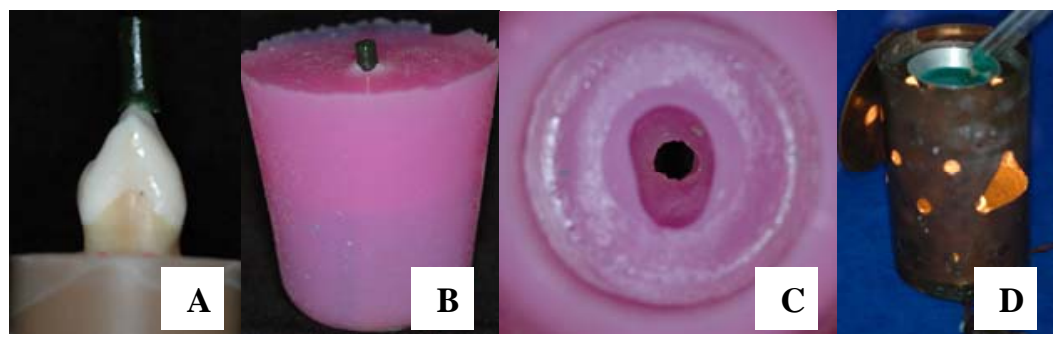

Figura 14- (A) Dente natural íntegro posicionado sobre o corpo de prova (B) moldagem do conjunto (corpo de prova/ coroa íntegra/ fio de cera) 
(C) molde do conjunto; (D) cera aspirada com uma seringa hipodérmica de vidro

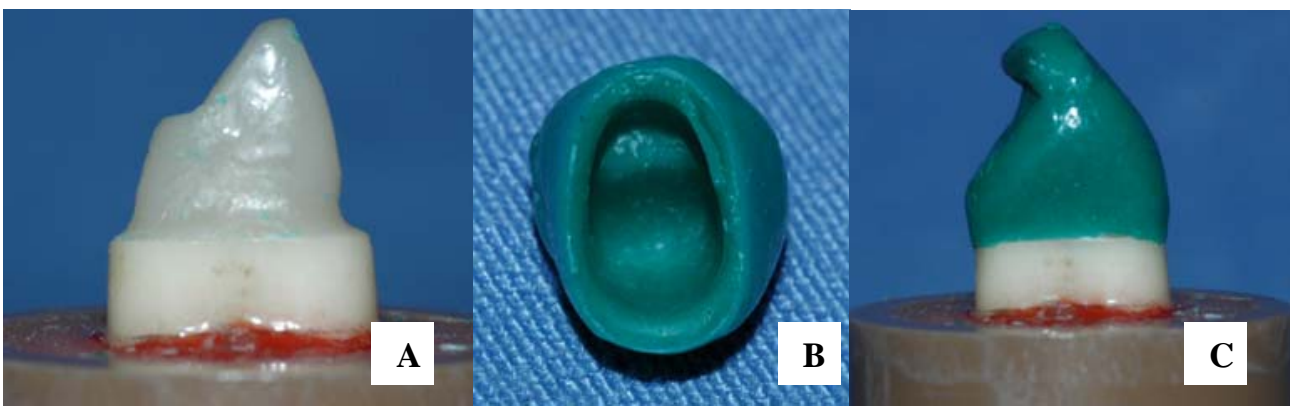

Figura 15 - (A) Núcleo de preenchimento vaselinado (B) excesso de cera removido a partir do término $(\mathrm{C})$ adaptação marginal e fio de cera sobre a superfície palatina

Após o enceramento das coroas, a inclusão dos padrões foi feita em anel de silicone com revestimento aglutinado por fosfato seguindo orientações do fabricante e fundidos com liga a base de Ni-Cr. Após a desinclusão, as coroas foram limpas com jatos de esfera de vidro e após a remoção dos condutos de alimentação, adaptadas nos respectivos dentes preparados dos corpos de prova. Para detectar áreas ou pontos de atrito que impediriam o assentamento das coroas nos respectivos preparos, foi aplicado liquido evidenciador de contato, com auxílio de um pincel pelo de marta $n^{\circ} 00$ nas paredes internas das fundições. As áreas de atrito e nódulos de fundição foram removidas com broca de aço esférica $n^{\circ} 02$, em alta rotação sob refrigeração constante. Este procedimento foi repetido até que 
uma película uniforme de evidenciador fosse observada. A verificação da adaptação foi realizada com auxílio de uma sonda exploradora n05 e com lupa frontal de quatro aumentos (figura 16).

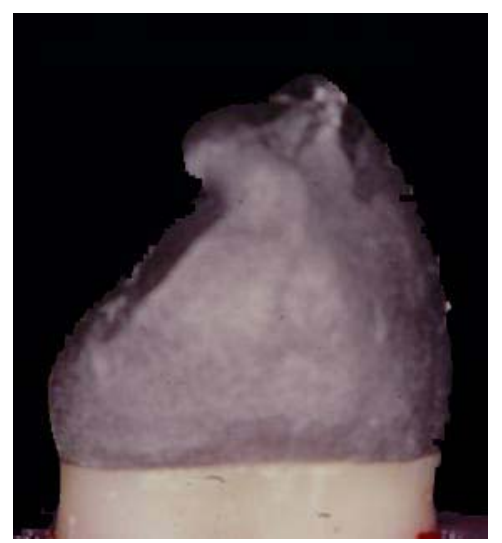

Figura 16 - Coroa total metálica fundida em $\mathrm{NiCr}$ adaptada ao espécime

\subsection{1 - Cimentação das coroas}

Após a adaptação das coroas, estas foram jateadas com óxido de alumínio numa granulação de $50 \mu \mathrm{m}$ e tratadas internamente com o sistema adesivo Scotchbond Multi-Uso segundo as recomendações do fabricante. O cimento resinoso Rely X ARC foi misturado e aplicado no interior dos coroas com uma espátula de inserção número 1. Cada coroa foi inserida em seu respectivo dente preparado e uma carga de $5,0 \mathrm{~kg}$ foi aplicada por 5 minutos sobre as mesmas (figura 17).

Os excessos foram removidos e cada face dos dentes foi fotopolimerizada por 40 segundos. 


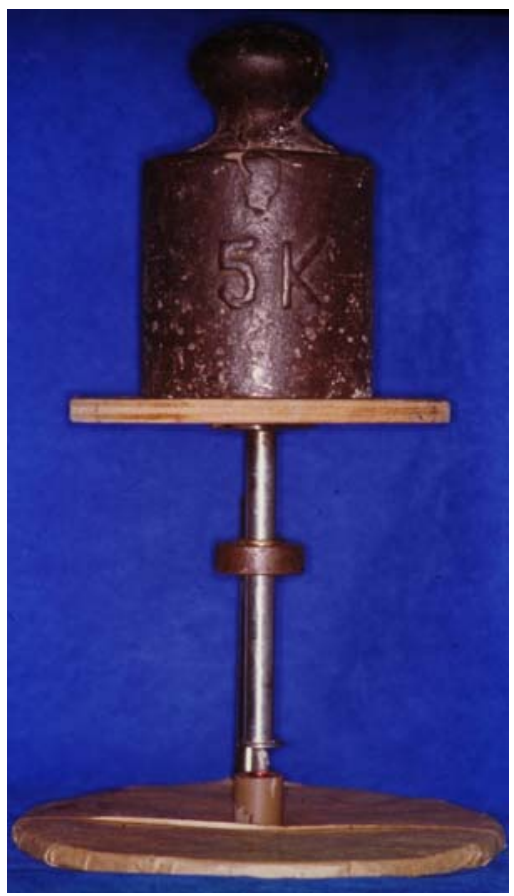

Figura 17 - Cimentação da coroa com aparato para padronização da carga e direção da força.

Após a cimentação das coroas, os corpos de prova foram submetidos aos ensaios de ciclagem dinâmica e compressão estática.

\subsection{2 - Teste de ciclagem mecânica}

Previamente a este testes, os espécimes foram visualizados sob microscopia ótica com um aumento de 30x para confirmação da integridade radicular obtida após a seleção dos mesmos no início desta pesquisa.

Para este teste, foi utilizada uma máquina de simulação de ciclos mecânicos da disciplina de Materiais Dentários da Faculdade de Odontologia de Piracicaba/ Unicamp (figura 18). 


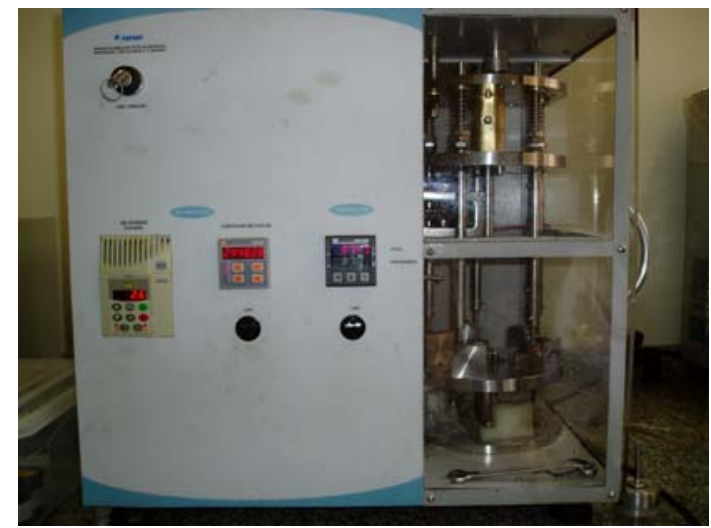

Figura 18-Máquina utilizada para ciclagem mecânica

Tal aparelho permite ensaios simultâneos de 5 corpos de prova (figura 19).

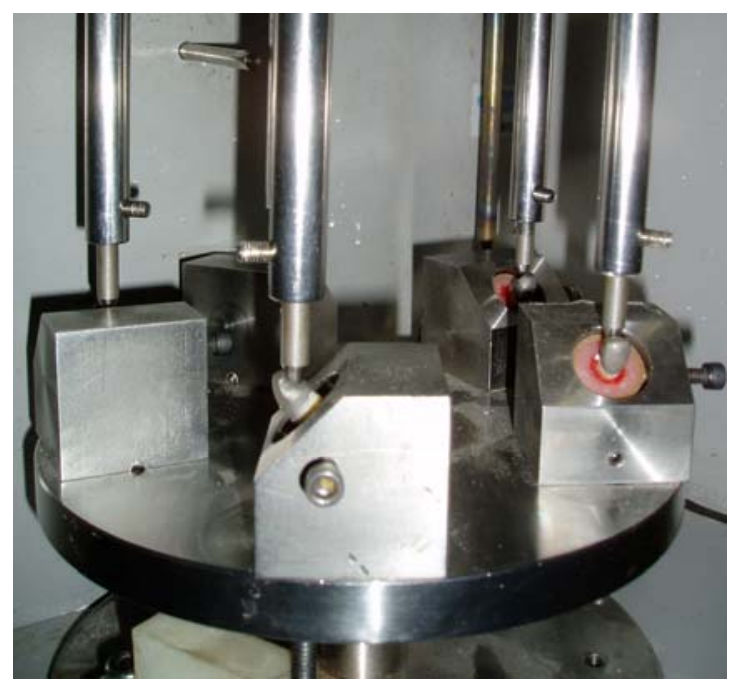

Figura 19 - Disposição dos corpos de prova no interior da máquina de ciclagem mecânica

Os espécimes foram posicionados numa angulação de $45^{\circ}$ em relação ao plano do solo e submetidos a impactos repetitivos direcionados 
3,0 mm abaixo da ponta incisal, sobre a superfície palatina das coroas, com carga de $30 \mathrm{~N}(3 \mathrm{~kg})$ na freqüência de $2.6 \mathrm{~Hz}$ e uma temperatura controlada na faixa de $37^{\circ} \pm 1,0^{\circ} \mathrm{C}$ até serem completados 250.000 ciclos ou a falência do conjunto coroa/núcleo/pino/(raiz), fosse por fratura ou decimentação.

Terminados os ciclos, o teste foi interrompido e se verificou possíveis falhas como: descimentação completa (coroa, núcleo e pino) ou parcial (coroa e núcleo) ,fratura e/ou trinca radicular utilizando sonda exploradora $\mathrm{n}^{\circ}$ 5.

\subsection{3 - Testes de resistência à fratura}

Após os ciclos mecânicos os espécimes foram submetidos ao teste de carga constante em uma máquina universal de ensaios utilizando uma célula de carga de $100 \mathrm{Kg}$ e velocidade de $0,5 \mathrm{~mm} / \mathrm{min}$ até a sua fratura. A força de compressão foi aplicada 3,0 mm abaixo da ponta incisal (figura 20).

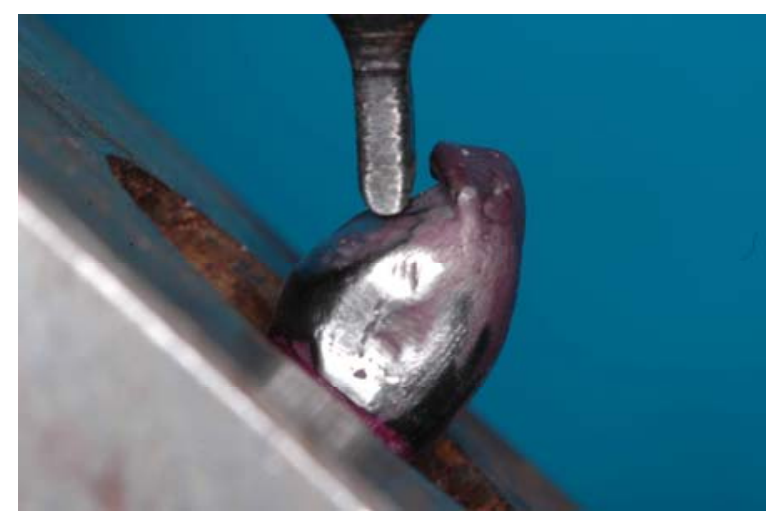

Figura 20 - Força de compressão foi aplicada $3,0 \mathrm{~mm}$ abaixo da ponta incisal 
Para que as coroas recebessem uma força de compressão incidindo em um ângulo de $135^{\circ}$ com o longo eixo da raiz, simulando um contato oclusal em classe I de Angle, utilizou-se um dispositivo metálico que permitiu o posicionamento dos corpos de prova em ângulo de $45^{\circ}$ em relação ao plano horizontal. Este dispositivo foi posicionado no interior de uma matriz metálica presa junto à base da máquina de ensaios (figura 21). Ao final de cada teste anotou-se os valores (em kgf) da força necessária para provocar a falha do conjunto dente/núcleo de cada grupo e os resultados submetidos a análise estatística para posterior dicussão dos mesmos.

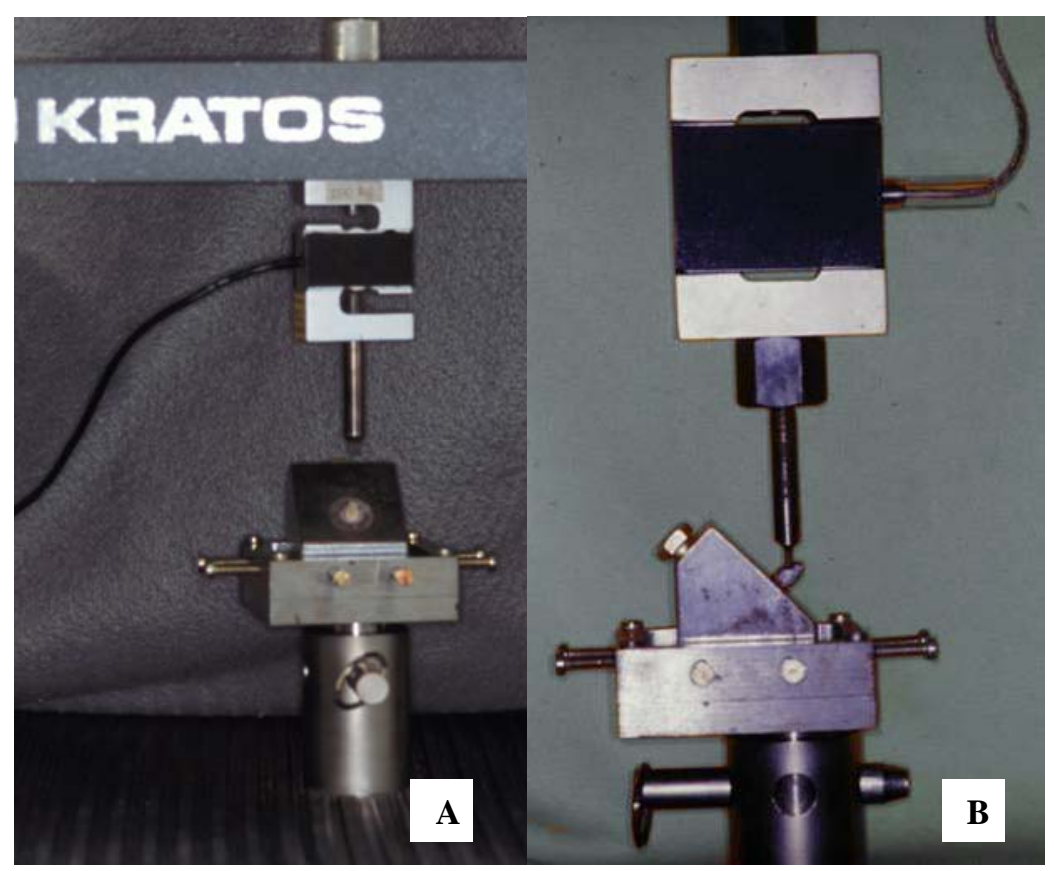

Figura 21 - Visualização das duas matrizes metálicas que permitiram a acomodação do corpo de prova a ser carregado (A - vista frontal, B - vista lateral) 


\subsection{4 - Análise do padrão de fratura}

A partir da localização da profundidade máxima da fratura, medida por sonda periodontal, cada espécime foi classificado hipoteticamente quanto à possibilidade de reabilitação pós-falha em fraturas favoráveis e desfavoráveis. Fraturas favoráveis foram definidas como aquelas localizadas até $1 \mathrm{~mm}$ abaixo do nível ósseo simulado. Já as desfavoráveis foram aquelas localizadas abaixo de $1 \mathrm{~mm}$ do nível ósseo simulado.

\subsection{5 - Análise estatística dos resultados}

Para comparação das médias de resistência à fratura entre os três grupos utilizou-se à análise de variância a um critério. Para comparações múltiplas o teste de Dunnett foi utilizado.

Para todos os testes estatísticos, foram utilizados o programa Statistica for Windows, versão 5.1 (StaSoft, Inc.) e Microsoft Excel.

Todos os resultados foram analisados adotando-se nível de significância de $5 \%(p \leq 0,05)$. 
5 - RESULTADOS 


\section{5 - RESULTADOS}

$\mathrm{Na}$ tabela 2 podem-se observar os valores individuais, médias e desvio padrão da resistência à fratura dos grupos testados neste estudo. Para melhor visualização dos resultados, encontra-se organizado na figura 22 às médias de resistência à fratura de cada grupo.

Tabela 2 - Valores de carga máxima individuais, médias e respectivos desvios padrão para cada condição experimental (valores em $\mathrm{kgf})$

\begin{tabular}{|c|c|c|c|}
\hline Espécime & Grupo I & Grupo II & Grupo III \\
\hline 1 & 69,30 & 35,05 & 27,45 \\
\hline 2 & $83,95\left(^{a}\right)$ & 27,30 & 27,85 \\
\hline 3 & 47,10 & 38,35 & 64,40 \\
\hline 4 & 27,20 & 52,30 & 26,15 \\
\hline 5 & 51,90 & 58,65 & 31,55 \\
\hline 6 & 41,45 & 51,45 & 53,90 \\
\hline 7 & 65,30 & 42,10 & 43,35 \\
\hline 8 & 53,80 & 42,40 & 40,05 \\
\hline 9 & 34,15 & 34,20 & 47,85 \\
\hline 10 & 73,00 & 36,20 & 56.75 \\
\hline $\begin{array}{l}\text { Média } \\
\text { Desvio Padrão }\end{array}$ & $\begin{array}{l}57,83 \\
15,25\end{array}$ & $\begin{array}{l}41,80 \\
9,68\end{array}$ & $\begin{array}{l}41,93 \\
13,63\end{array}$ \\
\hline
\end{tabular}

(') em negrito os valores máximos e mínimos 


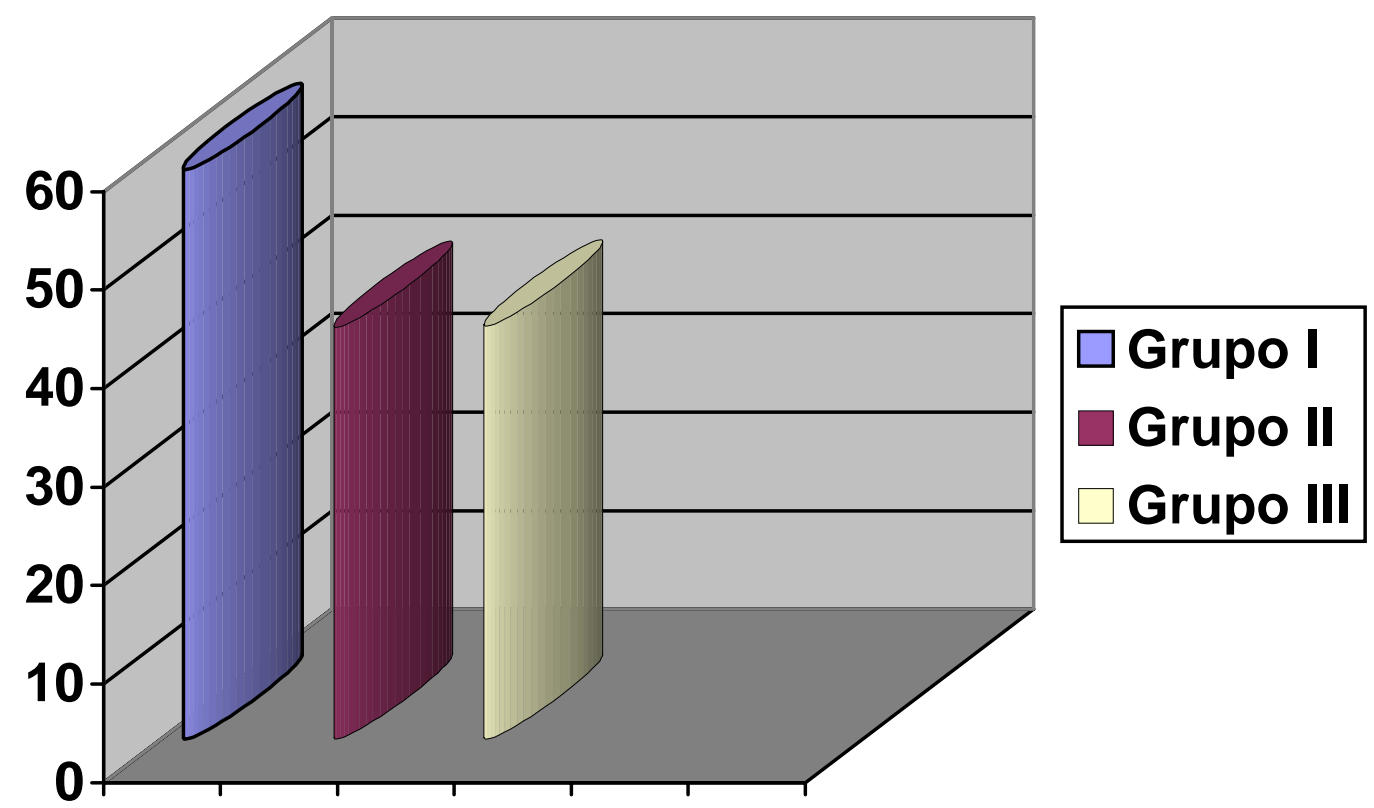

Figura 22 - Representação gráfica das médias de resistência à fratura dos três grupos experimentais

Para a análise dos resultados foi utilizado o teste de Análise de Variância (ANOVA) a um critério $(p<0,05)$ que mostrou haver diferença estatisticamente significativa entre os grupos (tabela 3). 
Tabela 3 - Teste estatístico de análise de variância a um critério aplicado aos valores de resistência à fratura

\begin{tabular}{c|c|c|c|c|c}
\hline Efeito & Ef & QM & QM & & \\
\hline Entre & Efeito & Efeito & F & p \\
tratamentos & 2 & 1699,832 & 849.916 & 4.974 &, $014^{*}$ \\
\hline
\end{tabular}

${ }^{*}$ estatisticamente significativo $(p<0,05)$

Desta forma realizou-se a comparação das médias através do método de Dunnett para comparações múltiplas $(p<0,05)$ (tabela 4).

Tabela 4 - Comparações individuais das médias - Método de Dunnett

\begin{tabular}{c|c|c}
\hline Grupo & Média & \\
\hline Controle & 57,835 & \\
\hline Grupo 2 & 41,800 & $\mathrm{x}$ \\
\hline Grupo 3 & 41,935 & $\mathrm{x}$ \\
\hline
\end{tabular}

Obs: Grupos que apresentam $\mathrm{x}$ não possuem diferença estatisticamente significativa entre si $(p<0,05)$

A localização e freqüência de todas as fraturas foram esquematizadas na figura 23 


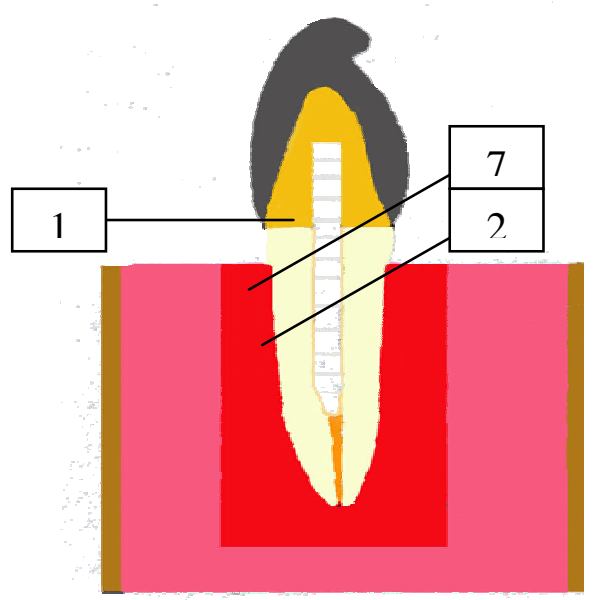

\section{Gl-Raízes íntegras}

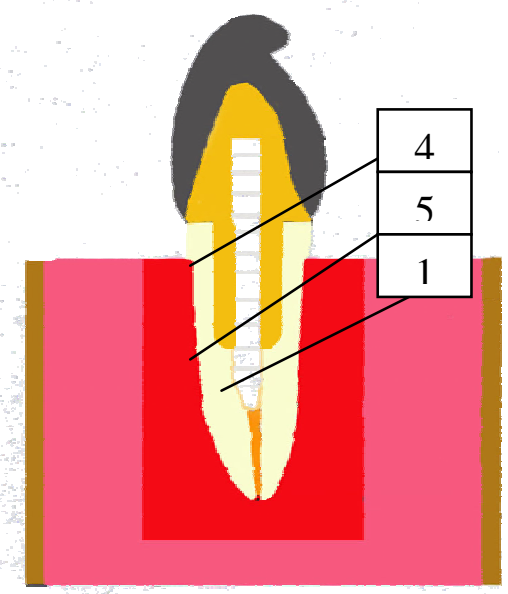

\section{Gll-Raízes parcialmente} fragilizadas

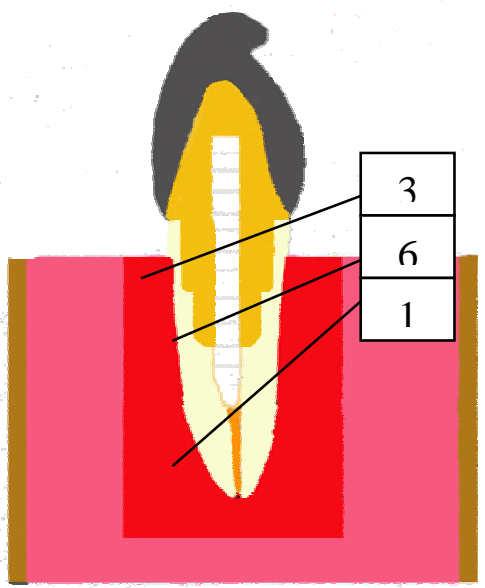

\section{GIII-Raízes amplamente} fragilizadas

Figura 23 - Localização e freqüência das fraturas nos 3 grupos avaliados 
A porcentagem dos espécimes, por grupo, quanto à possibilidade de reabilitação pós-compressão pode ser encontrado na tabela 5

Tabela 5 - Porcentagem dos espécimes quanto à possibilidade de reabilitação pós fratura conforme grupo

\begin{tabular}{ccc}
\hline \multirow{2}{*}{ Grupo } & \multicolumn{2}{|c}{ Reabilitação pós-compressão } \\
\cline { 2 - 3 } & Favorável & Desfavorável \\
\hline GI & $80 \%$ & $20 \%$ \\
GII & $40 \%$ & $60 \%$ \\
GIII & $30 \%$ & $70 \%$ \\
\hline
\end{tabular}


6 - DISCUSSÃO 


\section{6 - DISCUSSÃO}

Grande parte da literatura odontológica discute a maior ocorrência de falhas biomecânicas em dentes tratados endodonticamente do que em dentes vitalizados ${ }^{21,32,73}$. A idéia de maior fragilidade atribuída aos dentes despolpados está associada à alterações fisiológicas do tecido dentinário como desidratação dos túbulos dentinários ${ }^{9,32,92}$, à diminuição de sua elasticidade ${ }^{32,92}$ e, principalmente, à perda de estrutura dentária por cárie, fratura e aos procedimentos de instrumentação radicular e restauradores 37,73,80,92. Tal enfraquecimento, conseqüência destas mudanças, reflete a diminuição da capacidade destes dentes suportar cargas intra-orais e de resistir à fratura ${ }^{9,83,92}$.

Com estas condições estruturais, não raras vezes, para a restauração dos dentes tratados endodonticamente, há a necessidade de pinos intraradiculares para retenção dos núcleos e suporte das futuras coroas ${ }^{21}$. Desde o século XVIII há relatos de diferentes tipos de retenção intra-radicular que evoluíram ao longo do tempo quanto à composição do material, sua forma, seu desenho e sua coloração conforme limitação do sistema antecessor 10,15,20,22,34,60,61,66,79,83,86,88. Além dessa função primária, acreditou-se também que a restauração intra-radicular poderia reforçar dentes fragilizados $9,20,29,44,46,64,69,70,83,91$.

Porém, outros trabalhos vieram demonstrar que os pinos intraradiculares por si só não seriam capazes de fortalecer um dente tratado endodonticamente $31,33,91,92$. Outros afirmam que não havendo comprometimento da retenção de uma restauração, os pinos deveriam ser 
evitados como forma de preservação da estrutura dentinária radicular $11,15,18,28,31,33,41,92$

Apesar disso, pesquisas avaliando o reforço de raízes por pinos e materiais restauradores ainda vêm sendo realizadas $13,16,39,51,52,54,55,62,78,84,89$. Estas se concentram principalmente em situações de extrema fragilidade radicular, onde clinicamente, muitas vezes, tal dente pela complexidade da restauração e pela longevidade do tratamento ser questionada, tem sua extração indicada. Nestas condições o risco de falhas biomecânicas é ainda maior, já que os remanescentes radiculares estão fragilizados com canais extremamente alargados e paredes dentinárias delgadas como conseqüência de cáries extensas, uso prévio de núcleos com diâmetro largo, iatrogenia durante o tratamento endodôntico, rizogênese incompleta, reabsorção interna ou anomalias de desenvolvimento ${ }^{16,39,43,55,62}$.

$\mathrm{Na}$ tentativa de evitar a perda precoce e restabelecer a função na cavidade oral do remanescente radicular fragilizado, diferentes sistemas de pinos e materiais restauradores já foram associados ${ }^{13,16,39,51,52,54,55,62,78,84,89}$. Os diversos materiais restauradores testados como o cimento de ionômero de vidro resinoso $52,54,84$, o cimento resinoso ${ }^{52,55}$, a resina composta $13,51,52,54,78$, a fibra de polietileno ${ }^{39,62}$ e os pinos dentários a partir de dentes naturais ${ }^{13,39}$, são tentativas de se encontrar um substituto adequado ao tecido dentinário perdido.

Com a introdução dos pinos reforçados por fibra, surgiu um novo conceito de sistema restaurador onde os vários componentes da restauração (sistema adesivo, agente cimentante, pino e material de preenchimento) 
constituem um complexo estrutural mecanicamente homogêneo. Têm-se atribuído a este sistema de restauração em monobloco, com o emprego de materiais com propriedades físicas semelhantes às da dentina ${ }^{8,42,62}$, um comportamento frente às cargas funcionais similar à aquele de um dente íntegro ${ }^{66,79}$. Tal observação tem sido verificada por estudos clínicos que apresentaram resultados favoráveis quanto à ausência de fratura radicular quando estes pinos foram utilizados ${ }^{25,48,58}$.

Neste contexto, esta pesquisa avaliou se a reconstrução de raízes fragilizadas associando resina composta com pino de fibra de vidro aumentaria a resistência à fratura das mesmas quando comparadas a raízes íntegras.

O teste de ciclagem mecânica desta pesquisa foi realizado por 250.000 ciclos ininterruptos de carga aplicados com uma força de $3 \mathrm{Kg}$, com freqüência de $2.6 \mathrm{~Hz}$, numa temperatura controlada de $37^{\circ} \mathrm{C}$. Nenhum espécime falhou por fratura ou decimentação da coroa, núcleo ou pino.

A não observação de falhas após a ciclagem mecânica pode ter sido atribuída à baixa quantidade de ciclos. Este teste foi desenvolvido por 250.000 ciclos, na freqüência de $2,6 \mathrm{~Hz}$, significando que cada espécime ficou aproximadamente 27 horas sob impacto. BOLHUIS; GEE; FEILZER ${ }^{12}$, em 2004, utilizaram 1.000.000 de ciclos, perfazendo um total de 277 horas de teste de fadiga. Já MANNOCCI; FERRARI; WATSON ${ }^{49}$, em 1999, utilizaram 400.000 ciclos em seu estudo. Optou-se, no presente estudo, por um número de ciclos próximo ao utilizado por ISIDOR; ODMAN; BRONDUM ${ }^{38}$, em 1996, que foi de 260.000 ciclos. 
A quantidade de força aplicada na ciclagem mecânica pode influenciar no resultado final da fadiga ${ }^{95}$. Estudos variam quanto à carga, indo de $10 \mathrm{~N}$ com FREEMAN et al ${ }^{26}$,1998), passando por $30 \mathrm{~N}$ com HEYDECKE et al. ${ }^{35}$, 2002, e chegando a 250 N com ISIDOR; BRONDUN ${ }^{38}$,1992. Neste estudo optou-se por um valor de $3 \mathrm{Kg}$ próximo ao utilizado por HEYDECKE et al. ${ }^{35}$ em 2002.

Após a compressão estática, a análise da tabela 2 mostra que o grupo I apresentou a média mais alta de resistência à fratura $(57,83 \mathrm{Kgf}$ - desvio padrão de 15,25 ) com um valor cerca de $27,5 \%$ e $28 \%$ mais resistente que os grupos II (41,80 Kgf - desvio padrão de 9,68) e III (41,93 Kgf - desvio padrão de 13,63) respectivamente. Tal diferença de resistência pode ser explicada pela maior quantidade de remanescente dentinário no grupo I em relação aos outros dois grupos fragilizados ${ }^{89}$. A mesma justificativa não pôde ser utilizada para explicar um valor numérico médio cerca de 0,32\% maior do grupo III (raízes amplamente fragilizadas) em relação ao grupo II (raízes parcialmente fragilizadas).

O teste de análise de variância a um critério (ANOVA) verificou diferença estatisticamente significativa entre os grupos (tabela 3). Realizado o teste de comparações múltiplas (Método de Dunnett) identificou-se diferença significativa entre o grupo I (íntegras) e os grupos II e III (parcial e amplamente fragilizadas). Já entre os grupos II e III esta diferença não foi observada. Estes resultados concordam com a grande maioria dos trabalhos onde os maiores valores de resistência foram encontrados nos grupos com maior quantidade de tecido dentinário ao redor do 
pino $^{13,16,51,52,62,84,89}$. Exceção à regra foi observado por KAIZER ${ }^{39}$ e MARTINS ${ }^{54}$. KAIZER ${ }^{39}$ verificou um aumento da resistência de raízes com condutos medianamente alargados oferecido por pinos dentinários quando comparadas a raízes com alargamento convencional. Porém, ainda nesta pesquisa os mesmos pinos não obtiveram desempenho semelhante quando utilizados em raízes com condutos amplamente alargados $(0,5 \mathrm{~mm}$ de espessura dentinária remanescente). MARCHI et al. ${ }^{52}$, em 2003 utilizaram raízes com dimensões de comprimento e espessura de dentina cervical remanescente idênticas às utilizadas no grupo III desta pesquisa (14mm e 0,5mm respectivamente). Nestas condições a restauração de raízes amplamente fragilizadas com resina composta e pinos de fibra de vidro alcançou valores de resistência $(41,93 \mathrm{Kgf}$ - dp 13,63) semelhantes aos oferecidos pela resina composta e pinos de aço $(39,29 \mathrm{Kgf}-\mathrm{dp} 10,56) \mathrm{da}$ pesquisa citada ${ }^{52}$. No entanto, as raízes utilizadas na pesquisa de MARCHI et $\mathrm{al}^{52}$ foram bovinas e não pré-cicladas mecanicamente. Desta forma, os resultados oferecidos pelo grupo III desta pesquisa, que utilizou dentes humanos, podem ser considerados ainda mais promissores.

Apesar da ausência de diferença estatística significativa entre os grupos II e III, o grupo com maior desgaste dentinário apresentou maiores valores de resistência à fratura. Tal resultado pode ser justificado pelo maior volume de resina utilizado nas raízes amplamente fragilizadas quando comparado ao grupo parcialmente fragilizado. Esta maior quantidade de material pode ter intensificado características positivas da resina composta híbrida utilizada como maior resistência à compressão, dureza superficial e 
resistência ao desgaste ${ }^{1}$, e ainda, melhor absorção de impactos pelo módulo de elasticidade próximo ao da dentina ${ }^{72}$.

Considerando os terços radiculares cervical, médio e apical, a localização das fraturas ocorreu de maneira semelhante nos três grupos (Figura 23). Isto pode ser explicado levando-se em conta a flexibilidade (ou o módulo de elasticidade) do pino de fibra de vidro e também da resina composta como substitutos de comportamento próximo ao tecido dentinário $2,3,62,96$. No entanto, considerando a localização exata destas fraturas, em mm, houve maior ocorrência de fraturas mais profundas, com pior prognóstico restaurador, para os grupos fragilizados (Anexo 3). Tal fato mostrou que quanto maior a perda de tecido dentinário interno maior foi a ocorrência de fraturas irreversíveis quanto à chance de nova restauração (Tabela 5).

Apesar dos resultados deste experimento expressarem valores de resistência menores para as raízes fragilizadas do que as íntegras, a utilização de resina composta associada ao pino de fibra de vidro como substitutos dentinários pode ser considerada mais uma alternativa restauradora, já que também esta técnica tem a sua maior validade na manutenção de tais dentes ao invés da exodontia precoce ${ }^{16,27,43,45,46,51,55}$. No entanto, é importante afirmar que os achados deste estudo devem ser interpretados cuidadosamente, considerando os limites naturais de um teste laboratorial, que não necessariamente reproduz os modos de falha encontrados intra-oralmente. Além disso, existem também algumas 
dificuldades a serem superadas e melhor esclarecidas quanto à utilização de materiais que dependam da cimentação adesiva intra-radicular ${ }^{76}$.

Desta forma, faz-se necessário mais estudos laboratoriais e principalmente, num segundo momento, estudos clínicos prospectivos comparando técnicas e materiais utilizados como substitutos dentinários em remanescentes internamente fragilizados. 
7 - CONCLUSÕES 


\section{7 - CONCLUSÕES}

É importante afirmar que os achados deste estudo devem ser interpretados cuidadosamente, considerando os limites naturais de um teste laboratorial, que não necessariamente reproduz os modos de falha encontrados clinicamente. Diante das proposições apresentadas e dos resultados encontrados concluiu-se que:

A resistência à fratura de raízes fragilizadas (gll e gllI) foi significativamente menor do que àquela oferecida pelas raízes íntegras ( $\mathrm{gl}$ )

$>\quad$ Os grupos II e III apresentaram um maior número de fraturas localizadas abaixo do terço cervical com um conseqüente prognóstico restaurador desfavorável quando comparados ao grupo I 
ANEXOS 


\section{ANEXO 1 - Carta de aprovação do Comitê de Ética da FOB/USP}

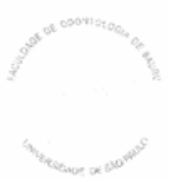

Processo $n^{\circ} 01 / 2005$

Bauru, 02 de março de 2005 .

\section{Universidade de São Paulo}

Faculdade de Odontologia de Bauru

Al. Dr. Octávio Pinheiro Brisolla, 9-75 - Bauru-SP - CEP 17012-901 - C.P. 73 PABX (0XX14)3235-8000 - FAX (0XX14)3223-4679

Comitê de Ética em Pesquisa

Senhor Professor,

O projeto de pesquisa encaminhado a este Comitê de Ética em Pesquisa em Seres Humanos, denominado "Resistência à fratura de dentes tratados endodonticamente restaurados com pinos de fibra de vidro quando submetidos a testes de ciclagem dinâmica e estática", de autoria de Lucas Villaça Zogheib, que será desenvolvido sob sua orientação, foi enviado ao relator para avaliação.

Na reunião de 23 de fevereiro de 2005 o parecer do relator, aprovando o projeto, foi aceito pelo Comitê, considerando que não existem infrações éticas pendentes.

Informamos que após o envio do trabalho concluido, este Comitê enviará o parecer final, que será utilizado para publicação do trabalho.

Atenciosamente,

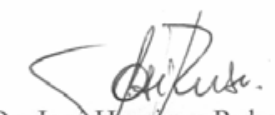
Prof. Dr. JoseyHenrique Rubo
Coordenador

Ilmº Sr. Prof. Dr. Accácio Lins do Valle

DD. Docente do Departamento de Prótese 


\title{
ANEXO 2 - Carta de informação ao paciente e termo de consentimento livre e esclarecido
}

\author{
UNIVERSIDADE DE SÃO PAULO \\ FACULDADE DE ODONTOLOGIA DE BAURU \\ DEPARTAMENTO DE PRÓTESE
}

\section{CARTA DE INFORMAÇÃO AO PACIENTE}

Estamos fazendo uma pesquisa, em laboratório, sobre pinos pré-fabricados para dentes que tiveram o canal tratado. Este esses pinos tem a função de proteger a estrutura dentária remanescente e permitir a confecção de uma coroa sobre ele. Deste modo, é importante saber qual a indicação para o pino, de modo que se possa fornecer um melhor tratamento ao paciente.

Mas, para isto precisaremos de dentes caninos superiores, que precisaram ser cxtraidos. Considerando que você passou por um cirurgia de extração dental, respeitosamente, pedimos que participe de nosso trabalho, doando o seu dente extraido, que se encaixa à nossa pesquisa.

Declaramos que a identidade de nenhum paciente será divulgada, e que este trabalho segue todas as normas do Cômite de Ética cm Pesquisa da Faculdade de Odontologia de Bauru

TERMO DE CONSENTIMENTO LIVRE E ESCLARECIDO

Pelo presente instrumento que atende às exigências legais, o Sr. (a) portador da

cédula de identidade após leitura minuciosa da CARTA DE

INFORMAÇÃO AO PACIENTE, devidamente explicada pelos profissionais $\mathrm{cm}$ scus minimos detalhes, ciente dos serviços e procedimentos aos quais será submetido, não restando quaisquer dúvidas a respeito do lido e explicado, firma seu CONSENTIMENTO LIVRE E ESCLARECIDO concordando em participar da pesquisa proposta.

Fica claro que o paciente ou seu representante legal, pode a qualquer momento retirar seu CONSENTIMENTO LIVRE E ESCLARECIDO e deixar de participar desta pesquisa e ciente de que todas as informações prestadas tornaram-se confidenciais e guardadas por força de sigilo profissional (Art. $9^{\circ}$ do Código de Ética Odontológica).

Por estarem de acordo assinam o presente termo.

Bauru-SP, de de

Assinatura do Paciente Prof. Dr. Adcácio Lins do Valle 
ANEXO 3 - Quadro 1 - Observações pós compressão

\begin{tabular}{|c|c|c|c|}
\hline & $\begin{array}{c}\text { Resistência à } \\
\text { Carga (Kg/f) }\end{array}$ & $\begin{array}{c}\text { Localização } \\
\text { da fratura }\end{array}$ & $\begin{array}{c}\text { Prognóstico } \\
\text { restaurador }\end{array}$ \\
\hline 1 & 69.300 & $1 \mathrm{~mm}$ & $\mathrm{~F}$ \\
\hline 2 & 83.950 & $1 \mathrm{~mm}$ & $\mathrm{~F}$ \\
\hline 3 & 47.100 & $2 \mathrm{~mm}$ & $\mathrm{D}$ \\
\hline 4 & 27.200 & $1 \mathrm{~mm}$ & $\mathrm{~F}$ \\
\hline 5 & 51.900 & $1 \mathrm{~mm}$ & $\mathrm{~F}$ \\
\hline 6 & 41.450 & $2 \mathrm{~mm}$ & $\mathrm{D}$ \\
\hline 7 & 65.300 & 0 & $\mathrm{~F}$ \\
\hline 8 & 53.800 & $1 \mathrm{~mm}$ & $\mathrm{~F}$ \\
\hline 9 & 34.150 & $1 \mathrm{~mm}$ & $\mathrm{~F}$ \\
\hline 10 & 73.000 & $1 \mathrm{~mm}$ & $\mathrm{~F}$ \\
\hline
\end{tabular}

\begin{tabular}{|c|c|c|c|}
\hline G 2 & $\begin{array}{c}\text { Resistência à } \\
\text { Carga }(\mathbf{K g} / \mathbf{f})\end{array}$ & $\begin{array}{c}\text { Localização } \\
\text { da fratura }\end{array}$ & $\begin{array}{c}\text { Prognóstico } \\
\text { restaurador }\end{array}$ \\
\hline 11 & 35.050 & $1 \mathrm{~mm}$ & $\mathrm{~F}$ \\
\hline 12 & 27.300 & $2 \mathrm{~mm}$ & $\mathrm{D}$ \\
\hline 13 & 38.350 & $2 \mathrm{~mm}$ & $\mathrm{D}$ \\
\hline 14 & 52.300 & $3 \mathrm{~mm}$ & $\mathrm{D}$ \\
\hline 15 & 58.650 & $1 \mathrm{~mm}$ & $\mathrm{~F}$ \\
\hline 16 & 51.450 & $2 \mathrm{~mm}$ & $\mathrm{D}$ \\
\hline 17 & 42.100 & $3 \mathrm{~mm}$ & $\mathrm{D}$ \\
\hline 18 & 24.800 & $1 \mathrm{~mm}$ & $\mathrm{~F}$ \\
\hline 19 & 34.200 & $2 \mathrm{~mm}$ & $\mathrm{D}$ \\
\hline 20 & 36.200 & $1 \mathrm{~mm}$ & $\mathrm{~F}$ \\
\hline
\end{tabular}

\begin{tabular}{|c|c|c|c|}
\hline G 3 & $\begin{array}{c}\text { Resistência à } \\
\text { Carga }(\mathbf{K g} / \mathbf{f})\end{array}$ & $\begin{array}{c}\text { Localização da } \\
\text { fratura }\end{array}$ & $\begin{array}{c}\text { Prognóstico } \\
\text { restaurador }\end{array}$ \\
\hline 21 & 27.450 & $2 \mathrm{~mm}$ & $\mathrm{D}$ \\
\hline 22 & 27.850 & $1 \mathrm{~mm}$ & $\mathrm{~F}$ \\
\hline 23 & 64.400 & $1 \mathrm{~mm}$ & $\mathrm{~F}$ \\
\hline 24 & 26.150 & $2 \mathrm{~mm}$ & $\mathrm{D}$ \\
\hline 25 & 31.550 & $3 \mathrm{~mm}$ & $\mathrm{D}$ \\
\hline 26 & 53.900 & $2 \mathrm{~mm}$ & $\mathrm{D}$ \\
\hline 27 & 43.350 & $2 \mathrm{~mm}$ & $\mathrm{D}$ \\
\hline 28 & 66.400 & $1 \mathrm{~mm}$ & $\mathrm{~F}$ \\
\hline 29 & 47.850 & $3 \mathrm{~mm}$ & $\mathrm{D}$ \\
\hline 30 & 56.750 & $7 \mathrm{~mm}$ & $\mathrm{D}$ \\
\hline
\end{tabular}

Observações

Prognóstico restaurador pós fratura: F-favorável: até $1 \mathrm{~mm}$ abaixo da DB D -desfavorável: 1,1 mm abaixo da DB 
ANEXO 4 - Carta de aprovação do Comitê de Ética da FOB para alteração de título

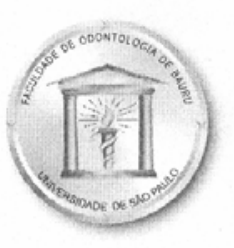

Processo $n^{\circ} 01 / 2005$

\section{Universidade de São Paulo \\ Faculdade de Odontologia de Bauru}

Al. Dr. Octávio Pinheiro Brisolla, 9-75 - Bauru-SP - CEP 17012-901 - C.P. 73

PABX (0XX14)3235-8000 - FAX (0XX14)3223-4679

Comitê de Ética em Pesquisa (3235-8356)

Bauru, 07 de julho de 2005.

Senhor Professor,

Informamos que após análise por este Comitê de Ética em Pesquisa em Seres Humanos, a alteração do título do projeto de pesquisa "Resistência à fratura de dentes tratados endodonticamente restaurados com pinos de fibra de vidro quando submetidos a testes de ciclagem dinâmica e estática" de autoria do C.D. Lucas Villaça Zogheib, desenvolvido sob sua orientação, para "Resistência à fratura de raizes fragilizadas restauradas com resina composta e pinos de fibra de vidro submetidas à ciclagem mecânica" foi aprovado considerando não haver alteração em sua metodologia.

Lembramos que após o envio do trabalho concluído, este Comitê enviará o parecer final, que será utilizado para a publicação do trabalho.

Atenciosamente,

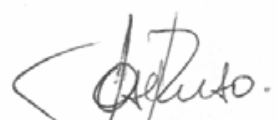

Prof. Dr. José Henrique Rubo Coordenador

$\| \mathrm{m}^{\circ} \mathrm{Sr}$. Prof. Dr. Accácio Lins do Valle

DD. Docente do Departamento de Prótese 
REFERÊNCIAS BIBLIOGRÁFICAS 


\section{REFERÊNCIAS BIBLIOGRÁFICAS*}

1 ABDAlLA, A. I.; ALHADAinY, H. A. 2-years clinical evaluation of class I posterior composites. Amer J Dent, v. 9, n.4, p.150-2, Aug. 1996.

2 AKKAYAN, B.; GÜLMEZ, T. Resistance to fracture of endodontically treated teeth restored with different post systems. J Prosthet Dent, v. 87, n. 4, p. 431-2, Apr. 2002.

3 AKKAYAN, B. An in vitro study evaluating the effect of ferrule lenght on fracture resistance of endodontically treated teeth restored with fiber-reinforced and zirconia dowel systems. J Prosthet Dent, v. 92, n. 2, p. 155-62, Aug. 2004.

4 AKSORNMUANG, J. et al. Micro tensile bond strength of a dualcure resin core material to glass and quartz fibre posts. $\mathbf{J}$ Dent, v. 32, p. 443-50, 2004.

5 AL-HARBI, F.; NATHANSON, D. In vitro assessment of four esthetic dowels to resin core foundation and teeth. $\mathbf{J}$ Prosthet Dent, v. 90, p. 547-55, Dec. 2003.

6 AL-HAZAIMEH, N.; GUTTERIDGE, D. L. An in vitro study into the effect of ferule preparation on the fracture resistance of crowned teeth incorporation prefabricated post and composite core restorations. Int Endod J, v. 34, p. 40-6, 2001.

\footnotetext{
*Normas recomendadas para uso no âmbito da Universidade de São Paulo, com base no documento "Referênciaa Bibliográficas”, emanadas do Conselho supervisor do Sistema Integrado de Bibliotecas da USP, em reunião de 20 de setembro de 1990.
} 
7 AQUILINO, S. A.; CAPLAN, D. J.; Relationship between crown placement and the survival of endodontically treated teeth. $\mathbf{J}$ Prosthet Dent, v. 87, n. 3 p. 256-63, Mar. 2002.

8 ASMUSSEN, E.; PEUTZFELDT, A.; HEITMANN, T. Stiffness, elastic limit and strength of newer types of endodontic post. $\mathbf{J}$ Dent, v. 27, p. 275-8, 1999.

9 BARABAN, D. J. A simplified method for making post and cores. J Prosthet Dent, v. 24, n. 3, p. 287-97, Sept. 1970.

10 BATEMAN, G.; RICKETTS, D. N.; SAUNDERS, W. P. Fibre based post systems: a review. Br Dent J, v. 195, n. 1, p. 43-8, July 2003.

11 BOLHUIS, H. P. B. et al. Fracture strength of different core buildup designs. Am J Dent, v. 14, n. 5, p. 286-90, Oct 2001.

12 BOLHUIS, P.; DE GEE, A. ; FEILZER, A. Influence of fatigue loading on four post-and-core systems in maxillary premolars. Quintessence Int, v. 35, n. 8, p. 657-67, Sept. 2004.

13 BONILLA, M. E. G. Avaliação da resistência à fratura transversal de raízes amplamente destruídas reconstruídas com núcleos. Bauru, 2001. 110p. Tese (Mestrado) - Faculdade de Odontologia de Bauru, Universidade de São Paulo.

14 BUTZ, F. et al. Survival rate and fracture strength of endodontically treated maxillary incisors with moderate 
defects restore with different post and core systems: an in vitro study. Int J Prosthodont, v. 14, n. 1, p. 58-64, 2001.

15 CAPUTO, A. A.; STANDLEE, J. P. Pins and posts-why, when and how. Dent Clin North Am, v. 20, n. 2, p. 299-311, Apr. 1976.

16 CARVALHO, C. A. T. et al. Structural resistance in immature teeth using root reinforcements in vitro. Dent Traumatol, v. 21, p. 155-9, 2005.

17 COHEN, B. I. et al. Cyclic fatigue testing of five endodontic post designs supported by four core materials. J Prosthet Dent, v. 78, n. 5, p. 458-64, Nov. 1997.

18 COHEN, B. I. et al. Fracture strength of three restorative materials supported with or without a prefabricated split-shank post. $\mathbf{J}$ Prosthet Dent, v. 78, n. 6, p. 560-5, Dec. 1997.

19 DRUMMOND, J. L.; BAPNA, M. S.; Static and cyclic loading of fiber- reinforced dental resin. Dent Mater, v. 19, p. 226-31, 2003.

20 FEDERICK, D. R. An application of the dowel and composite resin core technique. J Prosthet Dent, v. 32, n. 4, p. 420-5, Oct. 1974.

21 FERNANDES, A. S.; DESSAI, G. S. Factors affecting the fracture resistance of post-core reconstructed teeth: a review. Int $\mathbf{J}$ Prosthodont, v. 14, n. 4, p. 355- 6, 2001. 
22 FERNANDES, A. S.; SHETTY, S. COUTINHO, I. Factors determining post selection: a literature review. J Prosthet Dent, v. 90, n. 6, p. 556-62, Dec. 2003.

23 FINGER, W. J.; AHLSTRAND, W. M.; FRITZ, V. B. Radiopacity of fiber-reinforced resin posts. Am J Dent, v. 15, n. 2, p. 81-4, Apr. 2002.

24 FOKKINGA, W. A. et al. A structured analysis of in vitro failure load and failure modes of fiber, metal and ceramic post-andcore systems. Int J Prosthodont, v. 17, n. 4, p. 476-82, July/ Aug. 2004.

25 FREDRIKSSON, M. et al. A retrospective study of 236 patients with teeth restored by carbon fiber- reinforced epoxy resin posts. J Prosthet Dent, v. 80, p. 151-7, 1998.

26 FREEMAN, M. A. et al. Leakage associated with load fatigueinduced preliminary failure of full crowns placed over three different post and core systems. J Endod, v. 24, n. 1, p. 2632, Jan. 1998.

27 GOLDSTEIN, G.R.; HUDIS, S.I.; WIENTRAUB, D.E Comparison of four techniques for the cementation of posts. J Prosthet Dent, v. 55, n. 2, p. 209-11, Feb. 1986.

28 GOODACRE, C. J. Five factors to be considered when restoring treated teeth. Pract Proced Aesthet Dent, v. 16, n. 6, p. 45560 , July 2004.

29 GOODER, B.; ZHUKOVSKY, L.; BIVONA, P. L. Rehabilitation of thin-walled roots with light-activated composite resin: a case 
report. Compend Contin Educ Dent, v. 15, n. 1, p. 52-7, 1994.

30 GRANDINI, S.; BALLERI, P.; FERRARI, M. Scanning electron microscopic investigation of the surface of fiber posts after cutting. J Endod, v. 28, n. 8, p. 610-2, Aug. 2002.

31 GUZY, G. E.; NICHOLLS, J. I. In vitro comparison of intact endodontically treated teeth with and without endo-post reinforcement. J Prosthet Dent, v. 42, n. 1, p. 39-44, July 1979.

32 HELFER, A. R.; MELNICK, S.; SCHILDER, H. Determination of moisture content of vital and pulpless teeth. Oral Surg, v. 34, n. 4, p. 661-70, Oct. 1972.

33 HEYDECKE, G.; BUTZ, F.; STRUB, J. B. Fracture strength and survival rate of endodontically maxillary incisors with approximal cavities after restoration with different pos and cores systems: an in vitro study. J Dent, v. 29, n. 6, p. $427-$ 33, Aug. 2001.

34 HEYDECKE, G.; PETERS M. C. The restoration of endodontically treated, single- rooted teeth with cast or direct post and cores: a systematic review. J Prosthet Dent, v. 87, n. 4, p. 380-6, Apr. 2002.

35 HEYDECKE, G. et al. Fracture strength after dynamic loading of endodontically treated teeth restored with different post and core systems. J Prosthet Dent, v. 87, n. 4, p. 438-45, Apr. 2002. 
$36 \mathrm{HU}, \mathrm{Y}$. et al. Fracture resistance of endodontically treated anterior teeth restored with four post and core systems. Quintessence Int, v. 34, n. 5, p. 349-53, 2003.

37 HUANG, T. G.; SCHILDER, H.; NATHANSON, D. Effects of moisture content and endodontic treatment on some mechanical properties of human dentin. J Endod, v. 18, n. 5, p. 209-25, May 1992.

38 ISIDOR, F.; ÖDMAN, P.; BRØNDUM, K. Intermittent loading of teeth restored using prefabricated carbon fiber post. Int $\mathbf{J}$ Prosthodont, v. 9, n. 2, p. 131-6, 1996.

39 KAIZER, O. B. Avaliação da resistência à fratura de dentes tratados endodonticamente reconstruídos com pinos dentários e com pinos de fibras de polietileno. Bauru, 2003. 142p. Tese (Mestrado) - Faculdade de Odontologia de Bauru, Universidade de São Paulo.

40 KOVARIK, R. E.; BREEDING, L. C.; CAUGHMAN, W. F. Fatigue life of three core materials under simulated chewing conditions. J Prosthet Dent, v. 68, n. 10, p. 584-90, Oct. 1992.

$41 \mathrm{KREJCl}$, I. et al. Marginal adaptation, retention and fracture resistance of adhesive composite restorations on devital teeth with and without posts. Oper Dent, v. 28, n. 2, p. 127-35, 2003.

42 LASSILA, L. P. et al. Flexural properties of fiber reinforced root canal posts. Dent Mater, v. 20, p. 29-36, 2004. 
43 LUI, J. L. A technique to reinforce weakened roots with post canals. Endod Dent Traumatol, v. 3, n. 6, p. 310-4, Dec. 1987.

44 LUI, J. L. Composite resin reinforcement of flared canals using light-transmitting plastic post. Quintessence Int, v. 25, p. 313-9, 1994.

45 LUI, J.L. Depth of composite polymerization within simulated root canals using light-transmitting posts. Oper Dent, v .19, n. 5, p. 165-8, Sept./Oct. 1994.

46 LUI, J. L. Enhanced post crown retention in resin compositereinforced, compromised, root-filled teeth: a case report. Quintessence Int, v. 30, n. 9, p. 601-6, Sept. 1999.

47 MACCARI, P. C. A.; CONCEIÇÃO, E. N., NUNES M. F. Fracture resistance of endodontically treated teeth restored with three different prefabricated esthetic posts. J Esthet Restor Dent, v. 15 , n. 1, p. 25-31, 2003.

48 MALFERRARI, S.; MONACO, C.; SCOTTI, R. Clinical evaluation of teeth restored with quartz fiber-reinforced epoxy resin posts. Int J Prosthodont, v. 16, n. 1, p. 39-44, 2003.

49 MANNOCCI, F.; FERRARI, M.; WATSON, T. Intermittent loading of teeth restored using quartz fiber, carbon-quartz fiber and zirconium dioxide ceramic root canal posts. J Adhes Dent, v. 1, n. 2, p. 153-8, 1999. 
50 MANNOCCI, F.; SHERIFF, M.; WATSON, T. Three point bending test of fiber posts. J Endod, v. 27, n. 12, p. 758-61, 2001.

$51 \mathrm{MARCHI}, \mathrm{G}$. M. Resistência à fratura de raízes debilitadas reconstruídas morfologicamente com sistema adesivo e pinos intra-radiculares. Piracicaba, 1997. 106p. Dissertação (Mestrado) - Faculdade de Odontologia de Piracicaba, UNICAMP.

$52 \mathrm{MARCHI}, \mathrm{G}$. M. et al. Effect of different filling material in combination with intraradicular posts on the resistance to fracture of weakened roots. J Oral Rehabil, v. 30, p. 623-9, 2003.

53 MARTINEZ-INSUA, A. et al. Comparison of the fractures resistance of pulpless teeth restored with a cast post and core or carbon-fiber post with a composite core. J Prosthet Dent, v. 80, n. 5, p. 527-32, Nov. 1998.

54 MARTINS, L. R. Avaliação da resistência à fratura de raízes debilitadas reconstruídas morfologicamente com materiais adesivos. Piracicaba, 1995. 47p. Tese (Livre docência) Faculdade de Odontologia de Piracicaba, Universidade de Campinas, São Paulo.

55 MENDOZA, D. B. et al. Root reinforcement with a resin bonded performed post. J Prosthet Dent, v. 78, n. 1, p. 10-5, July 1997.

56 MILOT, P.; STEIN, R. S. Root fracture in endodontically treated teeth related to post selection and crown design. J Prosthet Dent, v. 68, n. 3, p. 428-35, Sept. 1992. 
57 MITSUI, F. H. O. et al. In vitro study of fracture resistance of bovine roots using different intraradicular post systems. Quintessence Int, v. 35, n. 8, p. 612-9, Sept. 2004.

58 MONTICELLI, F. et al. Clinical behavior of translucent-fiber post: a 2-year prospective study. Int J Prosthodont, v. 16, n. 6, p. 593-6, Nov./Dec. 2003.

59 MONTICELLI, F. ; GORACCI, C.; FERRARI, M. Micromorphology of fiber post-resin core unity: a scanning electron microcopy evaluation. Dent Mater , v. 20, n. 2, p. 176-83, Feb. 2004.

60 MORGANO, S. M.; BRACKETT, S. E. Foundation restorations in fixed prosthodontics: current knowledge and future needs. $\mathbf{J}$ Prosthet Dent, v. 82, n. 6, p. 643-57, Dec. 1999.

61 MORganO, S. M.; RODRIGUES, A. H. C.; SABROSA, C. E. Restoration of endodontically treated teeth. Dent Clin North Am, v. 48, n. 2, p. 397-416, Apr. 2004.

62 NEWMAN, M. P. et al. Fracture resistance of endodontically treated teeth restored with composite post. J Prosthet Dent, v. 89, n. 4, p. 360-7, Apr. 2003.

63 NON-METAL POST. Dent Adv, v. 20, n. 5, p. 1-6, June 2003.

64 OLIVEIRA JÚNIOR, I. L. Retenção intra-radicular (Sistema Luminex). Rev Assoc Paul Cir Dent, v. 51, n. 7, p. 53-6 ,jan./fev. 1997. 
65 PILO, R. et al. Effect of core stiffness on the in vitro fracture of crowned endodontically treated teeth. J Prosthet Dent, v. 88, n. 3, p. 302-6, Apr. 2002.

66 PITEL, M. L.; HICKS, L. N. Evolving technology in endodontic post. Compendium, v. 24, n. 1, p. 13- 28, Jan. 2003.

67 PONTIUS, O.; HUTTER, J. Survival and fracture strength of incisors restored with different post and core systems and endodontically treated incisors without corono-radicular reinforcement. J Endod, v. 28, n. 10, p. 710-5, Oct. 2002.

68 PURTON, D. G.; CHANDLER, N. P.; QUALTROUGH, A. J. Effect of thermocycling on the retention of glass-fiber root canal posts. Quintessence Int, v. 34, n. 5, p. 366-9, 2003.

69 RABIE, G. et al. Strengthening and restoration of immature teeth with acid-etch resin technique. Endod Dent Traumatol, v. 1, n. 6, p. 246-56, Dec 1985.

70 RABIE, G.; TROPE, M.; TRONSTAD, L. Strengthening of immature teeth during long-term endodontic therapy. Endod Dent Traumatol, v. 2, n. 1, p. 43-7, Feb. 1986.

71 RAYGOT, C. G.; CHAI, J.; JAMESON, L. Fracture resistance and primary failure mode of endodontically treated teeth restored with a carbon fiber-reinforced resin post system in vitro. Int $\mathbf{J}$ Prosthodont, v.14, n. 2, p.141-5, Mar./Apr. 2001. 
72 REAGAN, S. E. et al. Effects of cyclic loading on selected post and cores systems. Quintessence Int, v. 30, n. 1, p. 61-7, 1999.

73 REEH, E. S.; MESSER, H. H.; DOUGLAS, W.H. Reduction in tooth stiffness as a result of endodontic and restorative procedures. J Endod, v. 15, n. 11, p. 512-6, Nov. 1989.

74 REID, L. C.; KAZEMI, R. B.; MEIERS, J.C. Effect of fatigue testing on core integrity and post microleakage of teeth restored with different post systems. J Endod, v. 29, n. 2, p. 125-31, Feb. 2003.

75 ROBERTS, H. W. et al. The effect of a translucent post on resin composite depth of cure. Dent Mater, v. 20, p. 617-22, 2004.

76 SAHAFI, A. et al. Retention and failure morphology of prefabricated posts. Int J Prosthodont, v. 17, n. 3, p. 307-12, May/June 2004.

77 SANTOS, G. C.; EL-MOWAFY, O.; RUBO, J. H. Diametral tensile strenght of a resin composite core with nonmetallic prefabricated posts: an in vitro study. J Prosthet Dent, v. 91, n. 4, p. 335-41, Apr. 2004.

78 SAUPE, W.A.; GLUSKIN, A. H.; RADKE, R. A. A comparative study of fracture resistance between morphologic dowel and cores and a resin-reinforced dowel system in the 
intraradicular restoration of structurally compromised roots. Quintessence Int, v. 27, n. 7, p. 483-91, July 1996.

79 SCOTTI, R.; FERRARI, M. Pinos de fibra: considerações teóricas e aplicações clínicas. São Paulo: Artes médicas, 2003. 132 p.

80 SEDGLEY, C. M.; MESSER, H. H. Are endodontically treated teeth more brittle? J Endod, v. 18, n. 7, p. 332-5, July 1992.

81 SILVERSTEIN, W. H. The reinforcement of weakened pulpless teeth. J Prosthet Dent, v. 14, p. 372-81, 1964.

82 SIRIMAI, S.; RIIS, D. N.; MORGANO, S. An in vitro study of the resistance and the incidence of vertical root fracture of pulpless teeth restored with six post and core systems. $\mathbf{J}$ Prosthet Dent, v. 81, n. 3, p. 262-9, Mar. 1999.

83 SMITH, C. T.; SCUMAN, N. J.; WASSON, W. Biomechanical criteria for evaluating prefabricated post-and-core systems; a guide for restorative dentist. Quintessence Int, v. 29, p. 30512, 1998.

84 SOARES, J. Resistência à fratura de raízes enfraquecidas reconstruídas com sistemas adesivos. Bauru, 1999. 103 p. Dissertação (Mestrado) - Faculdade de Odontologia de Bauru, Universidade de São Paulo. 
85 SORENSEN, J.A.; ENGLEMAN, M.J. Ferrule design and fracture resistance of endodontically treated teeth. J Prosthet Dent, v. 63 , n. 5, p. 529-35, May 1990.

86 STANDLEE, J. P. et al. Analysis of stress distribution by endodontic posts. Oral Surg, v. 33, n. 6, p. 952-60, June 1972.

87 STRUB, J. R.; PONTIUS, O.; KOUTAYAS, S. Survival rate and fracture strength of incisors restored with different post and core systems after exposure in the artificial mouth. $\mathbf{J}$ Oral Rehabil, v. 28, p. 120-4, 2001.

88 TERRY, D. A. Restoring the intraradicular space with direct composite resins: fiber-reinforced post-and-core system. Pract Proced Aesthet Dent, v. 16, n. 6, p. 445-47, July 2004.

89 TJAN, A. H. L.; WHANG, S. B. Resistance to root fracture of dowel channels with various thicknesses of buccal dentin walls. J Prosthet Dent, v. 53, n. 4, p. 496-500, Apr. 1985.

90 TORBJÖNER, A.; FRANSSON, B. A literature review on the prosthetic treatment of structurally compromised teeth. Int $\mathbf{J}$ Prosthodont, v.17, n.3, p.369-376, May/June 2004.

91 TRABERT, K.C.; CAPUTO, A.A.; ABOU-RASS, M. Tooth fracturea comparison of endodontic and restorative treatments. $\mathbf{J}$ Endod, v. 4, n. 11, p. 341-5, Nov. 1978.

92 TROPE, M; MALTZ, D.O.; TRONSTAD, L. Resistance to fracture of restored endodontically treated teeth. Endod Dent 
Traumatol, v. 1, n. 5, p. 108-11, 1985.

93 TROPE, M; RAY JUNIOR, $H$. Resistance to fracture of endodontically treated roots. Oral Surg, v. 73, n. 1, p. 99-102, Jan. 1992.

94 USUMEZ, A. et al. Microleakage of endodontically treated teeth with different dowel systems. J Prosthet Dent, v. 92, n. 2, p. 163- 9, Aug. 2004.

95 WISKOTT, H.W.A.; NICHOLLS, J.I.; BELSER, U.C. Stress fatigue: basic principles and prosthodontic implications. Int $\mathbf{J}$ Prosthodont, v. 8, n. 2, p. 105-16, Mar./Apr. 1995.

XIBLE, A. A. Efeito de cargas cíclicas na resistência à fratura de dentes tratados endodonticamente reconstruídos com pinos pré-fabricados estéticos e metálicos restaurados com coroas de porcelana pura. Bauru, 2004. 122p. Tese (Doutorado) - Faculdade de Odontologia de Bauru, Universidade de São Paulo.

97 YOLDAS, O.; ALACAM, T. Microhardness of composites in simulated root canals cured with light transmitting posts and glass-fiber reinforced composite posts. J Endod, v. 31, n. 2, p. 104-6, Feb. 2005.

98 ZHI-YUE, L.; YU-XING, Z. Effects of port-core design and ferule on fracture resistance of endodontically treated maxillary central incisors. J Prosthet Dent, v. 89, n. 4, p. 368-73, Apr. 2003. 
ABSTRACT 


\section{ABSTRACT \\ Resistance to fracture of weakened roots restored with composite resin and glass fiber post submitted to cyclic loading}

The preservation and restoration of severely weakened pulpless teeth is a difficult and unpredictable procedure. This study evaluated the resistance to fracture and fracture patterns of weakened roots after restoration with glass fiber post, filling core of composite resin and total metallic crown submitted to cyclical and compressive load. Thirty upper canine teeth with similar dimensions were selected, being endodontic treatment performed. Samples were embedded and placed in a positioning jig. The teeth were divided into three groups in agreement with their cervical third thickness: group I (no weaken); Groups II (1.0mm) and III $(0.5 \mathrm{~mm})$ simulated roots partial and largely weakened. The roots of groups II and III were reconstructed with composite resin through transparent plastic post (Luminex System-Dentatus). All groups received nickel-chrome cast metallic crowns. Both posts and crowns were cemented with a dual resinous cement. The specimens were impacted at 45 degrees to the long axis of the tooth with a force of $30 \mathrm{~N}$ at a frequency of $2.6 \mathrm{~Hz}$ for a total of 250.000 impacts. After were taken to the Universal Testing Machine for the fracture resistance test in a $135^{\circ}$ and 0,5 $\mathrm{mm} / \mathrm{min}$ speed. The fracture resistance values were: Group I $-54,71 \mathrm{Kgf}$; Group II -40,04 Kgf; Group III -44,56 Kgf. Result show statistically significant differences in relation to the root conditions (ANOVA at one criterion $p<$ 0,05). The samples with a favorable repair were: Group I -100\%; Group II - 
40\%; Group III - 30\%. The presence of more bulk of dentinal structure increased the resistance to fracture. 